\title{
WestVirginiaUniversity
}

THE RESEARCH REPOSITORY @ WVU

Graduate Theses, Dissertations, and Problem Reports

2008

\section{Faculty incorporation of liberal Essential Learning Outcomes}

Shifang Li

West Virginia University

Follow this and additional works at: https://researchrepository.wvu.edu/etd

\section{Recommended Citation}

Li, Shifang, "Faculty incorporation of liberal Essential Learning Outcomes" (2008). Graduate Theses, Dissertations, and Problem Reports. 2862.

https://researchrepository.wvu.edu/etd/2862

This Dissertation is protected by copyright and/or related rights. It has been brought to you by the The Research Repository @ WVU with permission from the rights-holder(s). You are free to use this Dissertation in any way that is permitted by the copyright and related rights legislation that applies to your use. For other uses you must obtain permission from the rights-holder(s) directly, unless additional rights are indicated by a Creative Commons license in the record and/ or on the work itself. This Dissertation has been accepted for inclusion in WVU Graduate Theses, Dissertations, and Problem Reports collection by an authorized administrator of The Research Repository @ WVU.

For more information, please contact researchrepository@mail.wvu.edu. 
Faculty Incorporation of Liberal Essential Learning Outcomes

\title{
Shifang Li
}

\author{
Dissertation submitted to the \\ College of Human Resources and Education \\ at West Virginia University \\ in partial fulfillment of the requirements \\ for the degree of
}

Doctor of Education

in

Educational Leadership Studies

\author{
Richard Hartnett, Ed. D., Chair \\ Richard, D. Walls, Ph. D. \\ Ernest Goeres, Ph. D. \\ Ahmed Fakhri, Ph. D. \\ Susan Aloi, Ed.D.
}

Department of Advanced Educational Studies

Morgantown, West Virginia

2008

Keywords: Liberal Education, Essential Learning Outcomes, Faculty, Discipline, Accreditation Region, Professional, Applied, Carnegie Classification, Institution Type of Control

Copyright 2008 Shifang Li 


\author{
ABSTRACT \\ Faculty Incorporation of Liberal Essential Learning Outcomes \\ Shifang Li
}

In 2007, the Association of American Colleges and Universities recommended a set of Essential Learning Outcomes as objectives for twenty-first-century college learning. This study examined to what extent Essential Learning Outcomes are endorsed by faculty members with different teaching experience, across academic disciplines, Carnegie Classifications, institution types of controls, and accreditation regions.

Faculty Survey of Student Engagement (FSSE) 2004 data were used for this study with permission from the Indiana University Center for Postsecondary Research. ANOVA, $t$ test, were used for hypothesis tests. Regression and multiple regressions were used to calculate effect sizes, which quantified the differences between groups.

The major findings included: (1) the two groups of faculty (one is from professional and applied fields, and the other is from all remaining disciplines) differed significantly $(p<.01$ ) on endorsing eight of the 11 Essential Learning Outcomes (ELOs). Faculty members from professional and applied fields emphasized more on six of the eight significant ELOs than faculty members from others did. Most of the differences in magnitude are appreciable; (2) the two groups of faculty (one is from professional, and the other is a combination of applied and the remaining disciplines) differed significantly $(p<.01)$ on six of the 11 ELOs. Regarding these six significant ELOs, faculty members in professional gave more emphasis than the group of applied \& others did, and the differences in magnitude are appreciable; (3) faculty members across disciplines differed significantly $(p<.01)$ on endorsing each of the 11 ELOs, and most of the differences in magnitude are large; (4) faculty members from private and public higher institutions differed significantly $(p<.01)$ on five of the 11 ELOs. The differences in magnitude between them are modest to trivial; (5) faculty members from six accreditation regions differed significantly $(p<.01)$ on emphasizing six of the 11 ELOs. The differences in magnitude between these regions are appreciable; (6) faculty members from the three Classifications of Carnegie institutions differed significantly $(p<.01)$ on emphasizing five of the 11 ELOs. The differences in magnitude between them are modest to trivial; (7) faculty members with different teaching experience differed significantly $(p<.01)$ on emphasizing three of the 11 ELOs. The differences in magnitude between them are modest to trivial.

These findings should assist policy makers, professional organizations, and college leaders to make sound decisions in maximizing the adoption of the AAC\&U 2007 proposal. 


\section{AKNOWLEDGEMENTS}

I would like to express my genuine thanks to the members of my committee for their support and guidance as I completed my program of study and prepared this dissertation. To Dr. Richard Hartnett, he has provided continual guidance, advice, and motivation during the process of this study. To Dr. Richard Walls, he provided not only his expertise in quantitative research, but also most importantly his character and integrity towards academic research- which I believe will impact the rest of my life. To Dr. Susan Aloi, for the internship she created for me- it inspired my enthusiasm for the research. She also put a great amount work in editing my dissertation. To Dr. Ernest Goeres, for his kindness, and willingness to help out in every possible way to finalize my dissertation. To Dr. Ahmed Fakhri, for his thoughtful suggestions.

I would also like to express my heartfelt thanks to Dr. Cheryl Torsney, Dr. Joan Gorham and Dr. John C. Sencindiver. As academic administrators, they mentored me on educational leadership, trusted me to bring my knowledge into practice, and provided role models for my career. To them, I owe great respect. 


\section{DEDICATION}

I would like to dedicate this dissertation to my entire family. To my parents, Li, Weizhang, and Guo, Xiaoming. They provided unwavering support and encouragement for me to challenge myself educationally my entire life. To my brothers and sister, for taking care of my aging parents so that I could stay focused and accomplish this program of study. To my husband Zheng, Tai, and my daughter, Zheng, Tianran, it would have been impossible to accomplish this project without their support, understanding, and love. 


\section{TABLE OF CONTENTS}

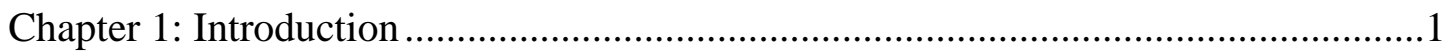

The Essential Learning Outcomes (ELOs) ...........................................................

The Purpose of the Study …...........................................................................6

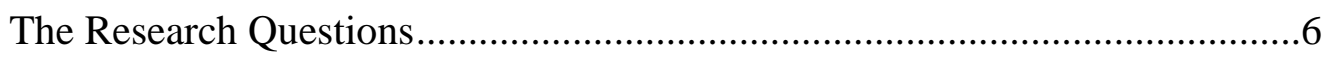

The Significance of the Study ........................................................................

Chapter 2: Literature Review .................................................................................9

Liberal Education in the Colonial Colleges ......................................................9

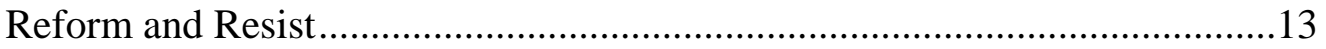

Liberal Education in Colleges' Transformation ...............................................16

The First Revival of Liberal Education ..........................................................25

The Second Revival of Liberal Education ..........................................................30

Liberal Education Reconsidered .....................................................................34

The Synthesis of Liberal and Practical Learning ...............................................39

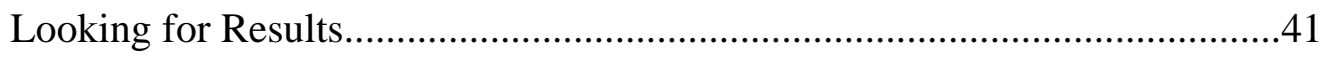

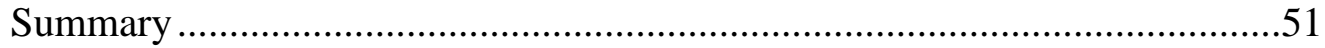

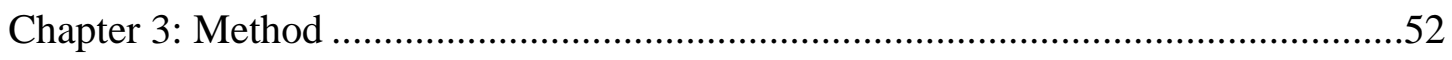

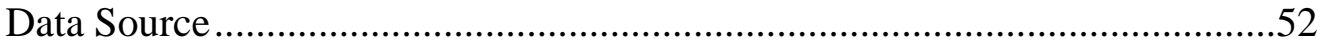

Research Design........................................................................................53

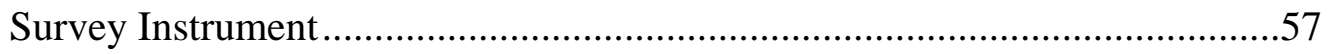

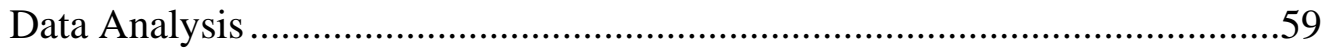

Chapter 4: Results .........................................................................................62

Research Question 1 .....................................................................................64 
Research Question 2 ....................................................................................69

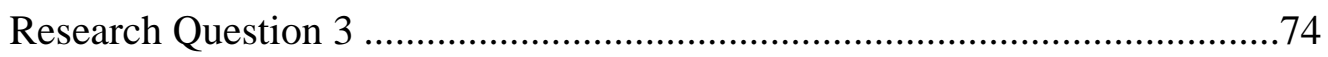

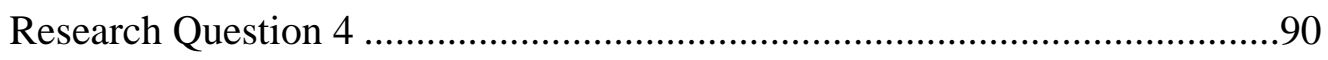

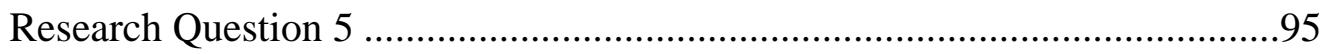

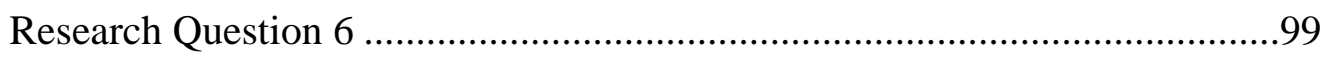

Research Question 7 ............................................................................102

Chapter 5: Conclusions and Implication..................................................................112

Faculty in Professional and Applied Fields' Support for the ELOs ..............112

Faculty in Professional Field' Support for the ELOs......................................114

Faculty across Disciplines Support for the ELOs ...........................................116

Faculty in Private and Public Institutions' Support for the ELOs ...................131

Faculty in Six Accreditation Regions Support for the ELOs...........................132

Faculty in the Three Types of Carnegie Institutions Support for ELOs ........137

Faculty with Different Teaching Experiences’ Support for ELOs ..................139

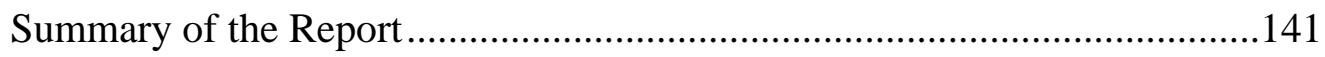

Recommendations for Further Study ………..............................................143

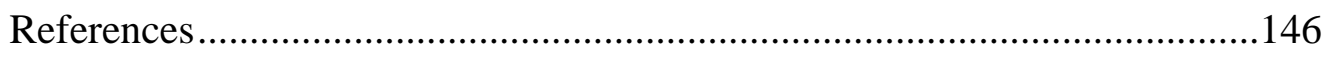

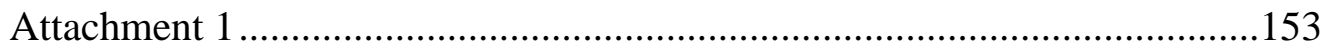

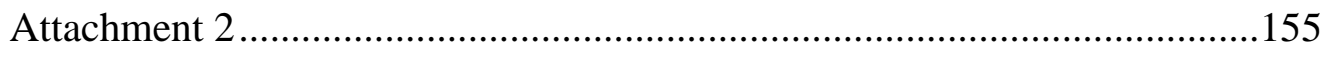




\section{LIST OF TABLES}

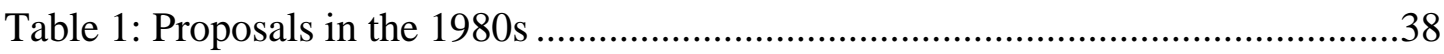

Table 2: General (liberal) Education Models.................................................................45

Table 3: The Essential Learning Outcomes Recommended by AAC\&U (2007 ..........49

Table 4: Re-mapping Liberal Education....................................................................50

Table 5: Variable Type and Variables .........................................................................56

Table 6: Essential Learning Outcomes and the Corresponding Items in FSSE............58

Table 7: ANOVA Tests ...................................................................................63

Table 8: Professional and Applied vs. Others in Emphasis on Quantitative Literacy (Outcome 3) ..............................................................65

Table 9: Professional \& Applied vs. Others in Emphasis on Information Literacy (Outcome 4).................................................................66

Table 10: Professional \& Applied vs. Others in Emphasis on Team Work

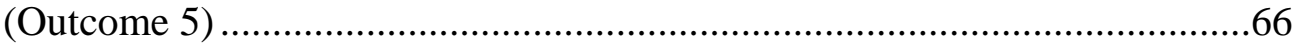

Table 11: Professional \& Applied vs. Others in Emphasis on Intercultural Knowledge and Competence (Outcome 7).................................................67

Table 12: Professional \& Applied vs. Others in Emphasis on Ethical Reasoning and Action (Outcome 8)

Table 13: Professional \& Applied vs. Others in Emphasis on Foundations and Skills for Life Long Learning (Outcome 9)

Table 14: Professional \& Applied vs. Others in Emphasis on Integrative Learning (Outcome10)

Table 15: Professional \& Applied vs. Others in Emphasis on Problem Solving (Outcome 11)

Table 16: Professional vs. Applied \&Others in Emphasis on Information Literacy (Outcome 4) 
Table 17: Professional vs. Applied \&Others in Emphasis on

Team Work (Outcome 5)

Table 18: Professional vs. Applied \&Others in Emphasis on

Civic Knowledge and Engagement (Outcome 6)

Table 19: Professional vs. Applied \&Others in Emphasis on

Ethical Reasoning and Action (Outcome 8)

Table 20: Professional vs. Applied \&Others in Emphasis on Integrative Learning (Outcome 10) .73

Table 21: Professional vs. Applied \&Others in Emphasis on

Problem Solving (Outcome11)

Table 22: Eight Discipline Difference in Emphasis on

Inquiry and Analysis,

Critical and Creative Thinking (Outcome 1) 76

Table 23: Eight Academic Discipline Difference in Emphasis on Written and Oral Communication (Outcome2)

Table 24: Eight Academic Discipline Difference in Emphasis on

Quantitative Literacy (Outcome 3)....

Table 25: Eight Academic Discipline Difference in Emphasis on Information Literacy (Outcome 4).

Table 26: Eight Academic Discipline Difference in Emphasis on Team Work (Outcome 5)

Table 27: Eight Academic Discipline Difference in Emphasis on Civic Knowledge and Engagement (Outcome 6) .....

Table 28: Eight Academic Discipline Difference in Emphasis on Intercultural Knowledge and Competence (Outcome 7)

Table 29: Eight Academic Discipline Difference in Emphasis on Ethical Reasoning and Action (Outcome 8)

Table 30: Eight Academic Discipline Difference in Emphasis on

Foundations and Skills for Life Long Learning (Outcome 9)

Table 31: Eight Academic Discipline Difference in Emphasis on Integrative Learning (Outcome 10) 
Table 32: Eight Academic Discipline Difference in Emphasis on

Problem Solving (Outcome 11)

Table 33: Carnegie Type Difference in Emphasis on Written and

Oral Communication (Outcome 2)

Table 34: Carnegie Type Difference in Emphasis on Civic Knowledge

and Engagement (Outcome 6)

Table 35: Carnegie Type Difference in Emphasis on Intercultural

Knowledge and Competence (Outcome 7)

Table 36: Carnegie Type Difference in Emphasis on Ethical

Reasoning and Action (Outcome 8)

Table 37: Carnegie Type Difference in Emphasis on

Problem Solving (Outcome 11)

Table 38: Institution Type of Control Difference in Inquiry and

Analysis, Critical, and Creative Thinking (Outcome 1)

Table 39: Institution Type of Control Difference in Emphasis

Written and Oral Communication (Outcome 2)

Table 40: Institution Type of Control Difference in Emphasis on

Civic Knowledge and Engagement (Outcome 6)

Table 41: Institution Type of Control Difference in Emphasis on Intercultural Knowledge and Competence (Outcome 7)

Table 42: Institution Type of Control Difference in emphasis on

Ethical Reasoning and Action (Outcome 8).

Table 43: Teaching Experience Difference in Emphasis on

Team Work (Outcome 5)

Table 44: Teaching Experience Difference in Emphasis on

Ethical Reasoning and Action (Outcome 8) 
Table 45: Teaching Experience Difference in Emphasis on Integrative Learning (Outcome 10) ...............................................................102

Table 46: Accreditation Region Difference in Emphasis on Written and Oral Communication (Outcome 2) .........................................104

Table 47: Accreditation Region Difference in Emphasis on Quantitative Reasoning (Outcome 3) .........................................................105

Table 48: Accreditation Region Difference in Emphasis on Information Literacy (Outcome 4).......................................................106

Table 49: Accreditation Region Difference in Emphasis on Civic Knowledge and Engagement (Outcome 6) ..

Table 50: Accreditation Difference in Emphasis on Intercultural Knowledge and Competence (Outcome 7) ...........................108

Table 51: Accreditation Difference in Emphasis on Ethical Reasoning and Action (Outcome 8) 109

Table 52: Effect Sizes and Effect Size Ranges for Seven Independent Variables and 11 Dependent Variables

Table 53: Faculty Report of Emphasizing Essential Learning Outcomes from 2004-2007 130 


\section{LIST OF FIGURES}

Figure 1: Others Emphasis on ELOs Compared with Prof. \& Applied......................114

Figure 2: Others Emphasis on ELOs Compared with Professionals ........................115

Figure 3: Discipline Emphasis on Inquiry, Analysis,

Critical and Creative Thinking

Figure 4: Discipline Emphasis on Written and Oral Communication 119

Figure 5: Discipline Emphasis on Quantitative Literacy 120

Figure 6: Discipline Emphasis on Information Literacy. 121

Figure 7: Discipline Emphasis on Team Work..... 122

Figure 8: Discipline Emphasis on Civic Knowledge 124

Figure 9: Discipline Emphasis on Intercultural Knowledge. 125

Figure 10: Discipline Emphasis on Ethical Reasoning and Action 126

Figure 11: Discipline Emphasis on Foundation and Skills for Life Long Learning

Figure 12: Discipline Emphasis on Integrative Learning ..... 128

Figure 13: Discipline Emphasis on Problem Solving 129

Figure 14: Regions Emphasis on Written and Oral Communication 133

Figure 15: Regions Emphasis on Quantitative Reasoning 133

Figure 16: Regions Emphasis on Information Literacy 134

Figure 17: Regions Emphasis on Civic Knowledge and Engagement 135

Figure 18: Regions Emphasis on Intercultural Knowledge and Competence .. 136

Figure 19: Regions Emphasis on Ethical Reasoning and Action 136

Figure 20: Teaching Experience Difference on ELOs 141

Figure 21: Engineering’s Emphasis on ELOs. 143 


\section{Chapter 1: Introduction}

Liberal education has played a fundamental role in providing an intellectual, moral, and cultural foundation for American higher education. The values of liberal education are enduring, but its practices have changed over time. The heritage of western culture, the scientific and industrial revolution, and the major political and economic developments have shaped the content and form of liberal education (Brubacher \& Rudy, 1958; Lucas, 1994; Rudolph, 1990; Scott, 1992; Thelin, 2004).

In the colonial period, liberal education was practiced through a common curriculum built on the ancient seven liberal arts, the trivium (grammar, logic, and rhetoric), and quadrivium (arithmetic, geometry, astronomy, and music). The purposes of liberal education were to educate young men and prepare them to become learned clergy, civic leaders, and eventually preserve and transmit the western culture (Brubacher \& Rudy, 1958; Rudolph, 1990). As the Industrial Revolution flourished at the end of the 19th century, the traditional common curriculum collapsed while specialization and vocational education made their way into undergraduate curriculum. For this reason, the traditional liberal education and professional education, which includes both special and vocational education, were seen as “antipodes” in the beginning of the twentieth century (Fang, 2004).

In 1945, the Harvard faculty committee made an effort to reconcile liberal education and professional education by demonstrating that the philosophy of liberal education is present in professional education as well (Harvard Red Book, 1945). However, throughout the remainder of the century, liberal education continued to be associated with the liberal arts and sciences disciplines, a few elite universities, or 
general education programs in research universities (Katz, 2005; Fong, 2004). The many professional and applied fields, including engineering, business, health and education, have not been seen as part of liberal education (Fang, 2004).

In the last three decades, many educators have called for a synthesis of both a liberal arts education with a vocational focus and vocationally oriented curriculum grounded in liberal learning (Chickering, 1982; Durden, 2002; Green \& Salem, 1988; Stark, 1987). Meanwhile, the professional societies of business, engineering, as well as medical and law professional organizations, have realized that broad knowledge and intellectual skills are vital for career success, and traditional professional programs that only focus on specific knowledge unique to the profession urgently needed to be reformed (Curry \& Wergin, 1993). Proposals made by national institutions, including Association of American Colleges (AAC) and National Institution of Education (NIE), during the same period of time started emphasizing the importance of integrating liberal education and vocational oriented programs (AAC, 1991; AAC, 1992; NIE, 1984). However, these proposals have not led to significant changes on the landscape of American higher institutions during the past decade (Ratcliff, Johnson, La Nasa, \& Gaff, 2001; Bok, 2006).

In 2005, the Association of American Colleges and Universities (AAC\&U) launched a decade-long project, Liberal Education and America's Promise (LEAP): Excellence for Everyone as a Nation Goes to College. The purpose of this initiative is clear: to universalize liberal education across all types of institutions and to unite its philosophy with vocational oriented education. LEAP's latest report, College Learning 
for the New Global Century (AAC\&U, 2007) provided a new conceptual and pedagogical framework for its implementation, and a rationale for this endeavor.

The AAC\&U (2007) report establishes again the indispensable position of liberal education in the undergraduate curriculum and pointed out that narrow learning is not enough to prepare students to meet the needs of the fast changing world. AAC\&U (2007) states, we live in a world that is being dramatically reshaped by scientific and technological innovations, global interdependence, across-cultural encounters, and changes in the balance of economic and political power. These waves of dislocating change will only intensify. The context in which today's students will make choices and compose lives is one of disruption rather than certainty, and of interdependence rather than insularity. This volatility also applies to careers. According to the AAC\&U (2007) report, studies show that Americans already change jobs ten times in the two decades after they turn eighteen. Thirty percent of our graduates may eventually work at jobs that do not yet exist; training for a specific career is insufficient as preparation for lifetime employment. Professional advancement is predicated on the capacity to change in response to new situations and challenges, to re-create oneself over time. This realization has engendered renewed appreciation for liberal education among the education community, business executives, and community leaders.

The Association of American Colleges and Universities currently defines liberal education as:

A philosophy of education that empowers individuals, liberates the mind from ignorance, and cultivates social responsibility. Characterized by challenging 
encounters with important issues, and more a way of studying than specific content, liberal education can occur at all types of colleges and universities. In contrast, general education is defined as "the part of the curriculum shared by all students. It provides broad exposure to multiple disciplines and forms the basis for developing important intellectual and civic capacities” (http://www.aacu.org/press_room/media_kit/what_is_liberal_education.cfm).

\section{The Essential Learning Outcomes}

The significance of the AAC\&U (2007) report is that it translates the philosophy of liberal education into a set of Essential Learning Outcomes based on their recalibration of college learning with the twenty-first-century global economy. These Essential Learning Outcomes include: I. Knowledge of human cultures and the physical and natural world. II. Intellectual and practical skills. III. Personal and social responsibilities. IV. The integrative learning. The intellectual and practical skills, the personal and social responsibilities, and integrative learning are further identified as the following 11 outcomes:

1. Inquiry and analysis, critical and creative thinking

2. Written and oral communication

3. Quantitative literacy

4. Information literacy

5. Teamwork

6. Civic knowledge and engagement-local and global

7. Intercultural knowledge and competence

8. Ethical reasoning and action 
9. Foundations and skills for lifelong learning

10. Synthesis and advanced accomplishment across general and specialized studies.

\section{Problem Solving}

With this view of liberal education, AAC\&U (2007) further recommends a pedagogical change for it: to extend the scope of liberal learning from the conventional general education curriculum in the first two years of college to all areas of studies, in different types of institutions, and through four years of undergraduate experience. This dramatic change presumes great responsibilities from every faculty member, and in every part of the academy to address the Essential Learning Outcomes in ways appropriate to their subjects.

The AAC\&U (2007) report calls on the educational community to change the focus of schooling from accumulating course credits to achieving the Essential Learning Outcomes, and make this a priority on campus. It urges determined leadership from presidents of higher institutions, trustees, and knowledgeable scholars to provide support for educational reform and renewal. Finally, the AAC\&U (2007) report highlights:

While recognized leaders can make higher achievement a priority, faculty and teachers who work directly with students are the only ones who can make it actually happen at all levels-nationally, regionally, and locally _ they will need to take the lead in developing guidelines, curricular and assignments that connect rich content with students’ progressive mastery of essential skills and capabilities... (p. 6). 
Despite the need to imbed in all courses learning experiences that lead to liberal education outcomes, many faculty members still believe that the recommended learning outcomes should be the responsibility of general education programs. Some faculty may be unaware that "liberal learning is just as much the business of the major and just as essential to a baccalaureate level of mastery in a field as it is to general education” (AAC\&U, 1998, p. 16).

\section{The Purpose of the Study}

The purpose of this study is to examine how faculty members emphasize and incorporate essential learning outcomes differently by disciplines, type of institutions, and other distinctive academic characteristics. In particular, it will focus on how differently faculty members foster intellectual and practical skills, personal and social responsibilities, and integrative learning (11 ELOs). These learning outcomes are the ones that AAC\&U (2007) emphasizes should be practiced extensively and progressively across the curriculum and in all areas of studies. The faculty members will be grouped by academic discipline, Carnegie type, accreditation region, status of institution, and teaching experience to conduct the analysis and address the research questions.

\section{The Research Questions}

1. Are there significant differences between the two groups of Professional \& Applied versus other disciplines (Others) on faculty reports of emphasizing Essential Learning Outcomes (11 ELOs)? 
2. Are there significant differences between the two group of Professional versus Applied \&Others’ faculty reports on emphasizing Essential Learning Outcomes (11 ELOs)?

3. Are there significant differences among eight academic disciplines on faculty reports of emphasizing Essential Learning Outcomes (11 ELOs)?

4. Are there significant differences among the Carnegie Classifications of institution types on faculty reports of emphasizing Essential Learning Outcomes (11 ELOs)?

5. Are there significant differences between institution types of control (public and private institutions) on faculty report of emphasizing Essential Learning Outcomes (11 ELOs)?

6. Are there significant differences among categories of teaching experience on faculty reports of emphasizing Essential Learning Outcomes (11 ELOs)?

7. Are there significant differences among accreditation regions on faculty reports of emphasizing Essential Learning Outcomes (11 ELOs)?

The Significance of the Study

Given the importance of revitalizing liberal education in all levels of undergraduate education, AAC\&U (2007) calls on new determination and new leadership commitments to implement the educational reform. But before the governing board, and college leaders make new policies and provide resource to advance the course, it is important to scrutinize the current practice of fostering liberal learning academically and organizationally. AAC\&U (2005) has analyzed data from 
the Faculty Survey of Student Engagement (FSSE), a national survey of college faculty, and provided some insight about the kinds of learning being emphasized by the surveyed faculty as a whole. It found that certain learning outcomes, such as analytical thinking, integration of learning, and computer use, seem to gather the most uniform support, while support for outcomes in quantitative literacy as well as in individual and social responsibility is considerably lower. These findings are important, but not sufficient especially considering that the emphasis of the reform proposed by AAC\&U (2007) is to extend the scope of liberal learning from the conventional general education curriculum in the first two years of college to all areas of studies, and from liberal arts colleges to all types of higher institutions. They have not examined how different types of higher education institutions, academic disciplines, and other academic characteristics contribute to the patterns of fostering recommended learning outcomes. This represents the focus of my study. It will help to identify areas of strength as well as aspects that may warrant attention for implementing the LEAP proposal. It will assist policy makers, professional organizations, and university and college leaders to make sound decisions in maximizing the adoption of LEAP initiative. 


\section{Chapter 2: Literature Review}

\section{Liberal Education in the Colonial Colleges}

Higher education in America started with colonial liberal arts colleges (Rudolph 1990). Modeled after Oxford and Cambridge in England, the colonial liberal arts college aimed to cultivate the mind of the young and prepare them to become learned clergy and civic leaders, and eventually preserve and transmit the intellectual culture of the Old World to the colonial America (Brubacher \& Rudy, 1958, Rudolph, 1990).

The seventeenth century Oxford and Cambridge model had three key components (Kimball, 1988). The humanist model of learning, the social etiquette of courtesy, and Christian ethics, "these three things combined together to produce the ideal of the Christian gentleman, which became the archetype of a liberally educated person in sixteenth-and seventeenth century England...(and this) model was quite naturally endorsed by the founders of Harvard College in 1636” (Kimball, 1988, p.303). Brubacher \& Rudy (1958) also confirmed “Oxford and Cambridge furnished the original model which the colonial colleges sought to copy. Harvard in turn, became the great prototype for all the later colleges of English America” (p. 3).

Fredrick Rudolph’s (1990) historical study clarified how the British model was manifested in the curriculum and practiced in the colonial liberal arts colleges. He described the courses of study in Harvard as such: first college year began with Latin, Greek, rhetoric, logic and Hebrew. In the second year, logic, Hebrew, and rhetoric were continued and natural philosophy was introduced. In the third year, students would be confronted with the three philosophies-natural, mental and moral-as well as 
geography. However, these courses relied heavily on lectures about Aristotle and other authorities rather than actual scientific experiments. During the last year, students reviewed Latin, Greek, Logic, and natural philosophy and began the study of mathematics. Divinity was a study for all four years. Curriculum in other colonial colleges might vary in order and proportion, but the intent, the emphasis and the subject matter were the same. Rudolph (1990) also pointed out the emphasis on Latin and Greek was a reflection that colonial colleges embraced both the Reformation ideal of the learned clergyman and the Renaissance ideal of the gentleman and scholar, because Latin was the language of Protestant Reformation, and Greek was the language of Renaissance learning.

Renaissance learning or humanistic learning can be traced back to its origin in the Greek city-states of the sixth and fifth centuries B.C. (Kimball, 1988). It was at that time that the rise of democratic institutions of governance, especially the assembly of free citizens, was gradually replacing the Homeric tradition of noble and valorous leadership. This change to democratic policy coincided with the flowering of Hellenic culture. The Greeks devoted a great deal of effort both to understanding their culture development and to considering how that culture could be transmitted to new generation of free citizens, who were to participate in governing the city-state. The issue was raised when considering what kind of education could accomplish this great purpose. On the one hand, Orators believed that the newly invented arts of grammar and rhetoric and the skills of composing, delivering and analyzing a speech should be central to the liberal education, because these skills were essential to the democratic city-state governance, where judicial or political decisions had to be made through 
communication and persuasion. On the other hand, Philosophers held the new arts of mathematics and logic to reflect the nature of liberal education. They promoted critical and speculative thought training, and believed freeing the mind and searching for the truth were more important than learning the truth itself (Kimball, 1988).

Throughout Western history, both the Philosopher's and Orator's ideal of liberal education had evolved, and each of them had prevailed in varying degrees in different times. For example, Kimball (1988) explained in the twelfth and thirteenth centuries, logic and mathematics emerged supreme as refined analytic tools. Rhetoric almost dropped from sight, while grammar was transmuted into linguistic analysis and stripped of its association with literature and tests. "Overall, the liberal arts became narrow and relatively brief 'speculative sciences ' intended to prepare the student for advanced and specialized study in the graduate faculties of the universities” (p. 302).

There were also other times when the Orator's ideal dominated the liberal arts education. When Greek civilization passed to the Romans between the first century B.C and the first century A.D., rhetoric became the crowning art upheld by the exemplary Roman orators Cicero and Quintilian. "Being the builders, lawyers, and administrators of an emerging empire, the Romans felt most sympathetic toward the educational view that emphasized public expression, political and legal discourse, and the literary tradition that described the noble virtues and orderly society of the past” (Kimball, 1988, p.301). They treated mathematical and scientific disciplines as bodies of facts providing technical information useful for speech. Later in the fourteenth and fifteenth centuries, the Ciceronian conception of liberal education was being rediscovered by the humanists of the Italian Renaissance. They celebrated it and 
advocated for rhetorical and literary learning. It further prevailed in the English universities in the fifteenth and sixteenth centuries and set up a model for the colonial colleges of America.

Harvard not only borrowed the humanistic curriculum from Oxford and Cambridge, but also the administrative structure.

The concept of effective religious control, the residential pattern, the idea of the colleges as essentially aristocratic in clientele and purpose reflected English experience... The emphasis was on teaching rather than on study; on students, rather than scholars; on order and discipline, rather than learning all this was derived from the patterns which had been emerging in the residential colleges of the English universities (Rudolph, 1990, p. 26). Despite the old-fashioned way of schooling, the courses of study and the purpose of liberal education in the seventeenth and eighteenth centuries held unity and integrity because "there was scarcely any perceptible difference between cultivation of the mind and preparation for the professions. The classical or humanistic curriculum accomplished both at one and the same time”(Brubacher \& Rudy, 1958, p. 279). However, when the expectation changed, or when the society needed more than just gentleman-scholars and clergymen from the higher institutions, the value and the unity of this liberal education faced a harsh reality check (Brint, 2002; Rudolph,1990; Thelin, 2004). 


\section{Reform and Resist}

After the American Revolutionary War in 1783, the United States was

experiencing fundamental political and economic development and population increase, but college enrollment actually declined (Cohen, 1998). What was happening in the newly born country was vividly described by Rudolph (1990):

The United States was exchanging Republicans and Federalists for Democrats and Whigs. It was building canals where turnpikes had sufficed, and before long it would be giving up canals in favor of railroads. A country that was hurrying into the future required colleges that would hurry along with it... (The colleges) would be asked to pass a test of utility” (Rudolph, 1990, p.112).

The traditional liberal education might have trained the gentlemen-scholars, who served as founding fathers, for the colonial America, but it was not producing engineers, agriculturists, technicians, architects, and other professionals that the new nation's construction needed. Neither could it keep up with the standards of higher learning in the European universities, especially the German university system, which had taken the leading position in scientific research and knowledge advancement by the early nineteenth century (Brubacher \& Rudy, 1958; Thelin, 2004).

Discontent with the traditional form of liberal education expressed itself, several colleges pioneered in reforming the traditional curriculum in the late $1700 \mathrm{~s}$ and early 1800s. They either added popular science, new branches of mathematics and modern languages into the classical program as a parallel course of study, or reduced 
the time allotted to the ancient subjects and substituted small prescribed doses of the new subjects (Rudolph, 1990; Thelin, 2004).

In the meantime, the lockstep practice in America colleges, such as discipline, recitation, memorization, class bond, and curriculum bond unity, was questioned by those who had attended German universities and came back with great enthusiasm to introduce American colleges to the German model. Although the attempt to make German universities out of the old fashioned colleges had to wait after the Civil War, the spirit of the German scholarship inspired and encouraged experimentation that tried to transform the old-time colleges into universities (Rudolph, 1990).

Agricultural and industrial arts appeared in Jefferson’s University of Virginia and Rensselaer Polytechnic Institute, both of which were founded in the 1830s (Brubacher \& Rudy, 1958). The idea of elective curriculum and graduate study were first introduced in Jefferson’s University, aiming for academic excellence and knowledge advancement although they did not achieve expected success due to various reasons: such as "too much novelty in the scheme”, "premature” and "terribly expensive” (Rudolph, 1990, p.127). Nevertheless, all these attempts and efforts happening after the American Revolutionary War challenged the traditional practice of liberal education. Yale’s faculty took the lead to defend it. They gave explicit and systematic statements to the principles by then taken for granted in their practice. The Yale Report of 1828 declared, “The two great points to be gained in intellectual culture are the discipline and the furniture of the mind; expanding its powers, and storing it with knowledge. The former of these is, perhaps, the more important of the two”(http://www.higher-ed.org/resources/Yale_Report.htm). 
Apparently, the committee held dearly to Aristotle's theory of psychology, which stated that the psyche or soul was a self-active principle manifesting itself in various powers or faculties such as memory, reason and imagination (Brubacher \& Rudy, 1958). By exercising these powers or faculties, students developed mental power which could be transferred at will from one study to another and from studies in general to the occupation of life. Hence the aim of a collegiate course should be to call the mind's faculties or potentialities into daily and vigorous exercise. Appropriate subjects inherently adapted to these ends, the committee held, included mathematics, ancient and modern English literature, logic, rhetoric, oratory, written composition and the physical sciences. These subjects were regarded as qualified for both disciplining and furnishing the mind.

Holding the view that one could not learn everything in a four-year course, the committee took the stance that the college should not furnish the student's mind with knowledge which might as easily or more effectively be gained outside college walls. Consequently, the committee shut the door on admitting professional studies into the curriculum and excluded mercantile, mechanical, and agricultural pursuits as well. These occupations, it held, can only be learned through practice in the counting room, the workshop and on the farm. In this manner, although the college might not offer training peculiar to specific occupations, it would provide the broad theoretical foundation for them all. Furthermore, the purpose of higher education should not be confined to preparing one to make a living. Rather, it should be directed to gaining broad knowledge, a comprehensive view, fine character, and the arts of living (http://www.higher-ed.org/resources/Yale_Report.htm). 
Rudolph (1990) noted "the Yale Report was a magnificent assertion of the humanist tradition” (p.134). It was embraced whole heartily by conservatives. James McCosh, a philosopher and the president of Princeton, declared a young man would not know what powers he had, unless he was required to pursue the full range of prescribed studies. Mark Hopkins, president of Williams, echoed: "for what could be more practical than a mind disciplined to turn its powers in any direction?” (as cited in Brubacher \& Ruby, 1958, p. 208). The Yale Report protected the antebellum college practice and the more or less fixed classical curriculum for almost another fifty years. However, the Yale Report did not end the controversy, and the contest between tradition and innovation remains as an issue to this day. With the end of the Civil War in 1865, higher education began a period of unprecedented reform, which transformed American colleges into universities.

\section{Liberal Education in the Period of Colleges' Transformation}

The college transformation was driven by a combination of political, social, and economic factors (Brubacher \& Rudy, 1958; Lucas, 1994; Rudolph, 1990; Thelin, 2004). The country came out from the Civil War as a united and expanding industrial nation. The abolishment of slavery by the democratic government destroyed the aristocrats' dreams built on agricultural estates, and accelerated industrialization and urbanization, which in turn freed thousands of Americans from a village orientation. This created remarkable opportunities in cities and inspired human ambition for social and economic mobility. Emerging from the rapid economic and political development was a more secular society with the erosion of religiously influence, and further demand for new technology and science. It was clear that "the old-time colleges would 
have to decide whether they would be instruments of the past or of the future, and how they would meet the now imperative needs of an expanding industrial nation and of a developing national power” (Rudolph, 1990, p.242). Lucas (1994) emphasized the growth in surplus capital and a new generation of prominent college presidents as contributing factors to the reform. It was with the aid of federal land grants and the accumulated fortunes from industrial entrepreneurs, railroad tycoons and business magnates that college presidents and reformers built new institutions and radically transformed old ones.

The Morrill Act of 1862 put federal largesse at the disposal of state government, and helped to develop a new network of institutions with a popular and practical orientation. These land-grant institutions, including state universities and land-grant colleges, did the most to change the outlook of the American people toward college. Attending colleges and getting a diploma were no longer a privilege for the fortunate few, but also for the daughters and sons of yeomen. "It sustained the yeoman," and in the meantime, "it liberated the farm boy who would make his way in the city” (Ruldolph, 1990, p.265). Others believed that, over time, state universities and land-grant colleges came to represent the fullest expression possible of Jacksonian egalitarian and democratic ideals applied to higher education (Lucas, 1994).

In 1867, Johns Hopkins pledged his fortune in Baltimore and Ohio Railway stock to the creation of the first German style university in Baltimore. Under the leadership of Daniel Coit Gilman, Johns Hopkins University was dedicated to scientific research by putting the faculty's need at the center of the institution. Instead of being "in Loco Parentis," faculties were expected to contribute to knowledge 
advancement. They were given the right to pursue their investigations wherever they might lead, and to disseminate the results through teaching or publication without interference from external authorities. They developed laboratories, established research libraries, organized seminar groups, subdivided specialized courses, and built up departments composed of like-minded individuals. Students were allowed to choose whatever courses they preferred, with no formal attendance requirements or tests preliminary to their applying for a final degree examination (Lucas, 1994).

Johns Hopkins University had brought to the scene of American higher education almost a spirit of revolution. It substituted the acceptance of revered religious truth for a search of scientific truth. It focused on an understanding of this world instead of preparation for the next one. It “elevated man's reason to a position it had not before attained in the United States. It released the energies of scholarship, combined them with the national impulse to human betterment and material progress" (Rudolph, 1990, p. 275).

Before long, John’s Hopkins' spirit penetrated everywhere, not only in the state universities but also in the most prestigious institutions such as Harvard, Columbia, Chicago, Clark, etc. President Charles Eliot of Harvard acknowledged publicly that "it was Johns Hopkins that aspired to the development of the Graduate School of Harvard University” (Lucas, 1994, p.173).

Reinforcing the utilitarian and scientific movement were other educational developments. Andrew Dickson White of Cornell University promised in 1868 to build a university "where any person can find instruction in any study" (as cited in Lucas, 1994, p.145). The "Wisconsin Idea" suggested the university as an instrument 
for social service. The most influential was Charles Eliot's elective curriculum principle for undergraduate education, which was proposed in his inauguration in Harvard in 1869.

President Eliot's elective principle established the fundamental equality of all branches of knowledge no matter how nontraditional, and in the meantime it attended to individual traits of different minds, which had been neglected in education. He urged that all requirements be abolished, and allowed students to pick and choose the course of study based on their own individual interests, preferences, and career aspirations. The conservatives fought against the idea of elective policy immediately, but President Eliot was unmoved. He and his supporters, such as Andrew Dickson White at Cornell, held that the elective system would solve the motivation problem, and generate energetic and vigorous learning. They also believed that it was both necessary and desirable to encompass a full range of scientific and technical disciplines within a university's offerings, though not necessarily at the expense of the older more established classical disciplines and humanistic belles-letters. But to achieve this goal, they realized, it would no longer be possible to require everyone to complete exactly the same curricular regimen. Human knowledge had expanded to the point where no one was capable of comprehending the whole. Disciplinary specialization, to some extent, was therefore both inevitable and better adapted to the modern world (Lucas, 1994; Thelin, 2004). In Eliot's forty years of administration, Rudolph (1990) observed, “the prescribed classical curriculum in the American college would come tumbling down with such force that a later generation at Harvard would turn to General Education as a remedy for his success” (Rudolph, 1990, p. 244). 
By the dawn of the twentieth century, American universities were described as "magnificent democratic institutions" with the nature of "coming together of the English college tradition, the research ideal of the German university, and the American ideal of the university as an instrument of public services” (AAC, 1985, p. 4). The old unity and integrity of liberal education were utterly destroyed. The more or less fixed curriculum of the mid-1800s was supplanted by the elective system and a vast array of utilitarian courses of study. There was no agreement on a fixed body of knowledge as a mark of an educated person (Lucas, 1994).

In the early years of the land grant institutions, the liberal phase of study was prominent simply because of the lack of an adequate body of knowledge in the new fields. With the rapid development of applied science, the technical specialties accumulated into a formal body of knowledge for teaching, which unavoidably caused dispute regarding what knowledge was more important for undergraduate education (Lucas, 1994).

In fact, the Yale's "mental discipline” theory itself fell victim to science in the first decade of the twentieth century when the mounting evidence of series scientific research found that the amount of transfer of learning from one subject to another was nowhere near so large nor so automatic as had been assumed for centuries (Bok, 2006; Brubacher \& Rudy, 1958). Thereafter, some business leaders joined the reformers in opposing classical education. They argued, if knowledge was not transferable, "why not study those bodies of knowledge that are commercially valuable” (Boyer, 1987, p.64)? 
While these developments were occurring in the land grant institutions, changes were concomitantly occurring in the liberal arts colleges. According to Dressel, Mayhew, and McGrath (1960), in the earlier twentieth century, the liberal arts colleges slowly added a few courses with a vocational orientation. After World War I, offering of such courses as accounting, medical technology, education, and nursing with a patent vocational objective were increased.

Preceding these developments, however, and occurring more rapidly was the addition of new subject matter in emerging academic disciplines such as physics, chemistry, modern foreign languages and the social sciences. These fields expanded and continuously splintered into narrower areas of research and teaching during the latter half of the $19^{\text {th }}$ century. Dressel, Mayhew, and McGrath (1960) indicated "the various departments in the liberal arts college soon offered instruction which by design, content and narrowness of intellectual methodology was no less vocational than the offerings in the professional schools” (p. 3). Separations and divisions, not unity, marked the undergraduate program. It often had little to do with the interests or the life activities of the great mass of students who did not pursue graduate study, but sought only a Bachelor of Arts or Bachelor of Science degree.

Certainly, disputing the doctrine of the "mental discipline" theory in the Yale's Report did not end the debate between the reformers and the defenders of classical curriculum in the process of college transformation. If Yale Report had emphasized a transferable character of liberal education, which had fallen victim to scientific research, the new humanists, or rational humanists as historians named them (Rudolph, 1990; Brubacher \& Ruby, 1958), focused more on the value of liberal 
education that contributes to the development of a whole person, and its extension of sustaining a good society, and western culture.

John Hennery Newman's The Idea of a University (1853/1976) was among the most famous for clarifying the value of liberal education and in defining it after the Yale’s Report of 1828. Newman (1853/1976) began with an uncompromising assertion in the preface that a university is primarily "a place of teaching universal knowledge. This implies that its object is, on the one hand, intellectual, not moral; and on the other, that it is the diffusion and extension of knowledge rather than the advancement” (p. IX). Eloquently, he described the benefits that an individual could realize from a liberal arts education:

A university training is the great ordinary means to a great but ordinary end; it aims at raising the intellectual tone of society, at cultivating the public mind, at purifying the national taste, at supplying true principles to popular enthusiasm and fixed aims to popular aspiration, at giving enlargement and sobriety to the ideas of the age, at facilitating the exercise of political power, and refining the intercourse of private life. It is the education which gives a man a clear conscious view of his own opinions and judgments, a truth in developing them, an eloquence in expressing them, and a force in urging them. It teaches him to see things as they are, to go right to the point, to disentangle a skein of thought, to detect what is sophistical, and to discard what is irrelevant. It prepares him to fill any post with credit, and to master any subject with facility. It shows him how to accommodate himself to others, how to throw himself into their state of mind, how to bring before them his own, how to influence them, how to come 
to an understanding with them, how to bear with them. He is at home in any society, he has common ground with every class; he knows when to speak and when to be silent; he is able to converse, he is able to listen; he can ask a question pertinently, and gain a lesson seasonably, when he has nothing to impart himself; he is very ready, yet never in the way; he is a pleasant companion, and a comrade you can depend upon; he know when to be serious and when to trifle, and he has a sure tact which enables him to trifle with gracefulness and to be serious with effect. He has the repose of a mind which lives in itself, while it lives in the world, and which has resources for its happiness at home when it cannot go abroad. He has a gift which serves him in public, and supports him in retirement, without which good fortune is but vulgar, and with which failure and disappointment have a charm (p.154-155). Newman (1853/1976) was against the idea of specialization in undergraduate education. He insisted that the university should offer broad range of courses, and students should be nurtured in a scholarly community. Narrow learning was to be avoided because "all branches of knowledge are connected together," and "there is no science but tells a different tale, when viewed as a portion of a whole, from what it is likely to suggest when taken by itself, without the safeguard... of others”(p. 94).

Irving Babbitt, a philosophy professor at Harvard was a leading rational humanist against Eliot's curriculum reform. He criticized Eliot's elective curriculum as pandering to student's interest and reflecting narrow utilitarian motives. Sarcastically, he stated: "The wisdom of all ages is to be naught compared with the inclination of a sophomore. Let us hear less about service and power, more about 
wisdom and character. Let us indeed, assert the validity of intelligent control, the possibility of liberal education, an interest in what is human about a student rather than in what is merely individual about him”(as cited in Rudolph, 1990, p.452).

Norman Foerster, Paul Shorey, and Robert M. Hutchins were other notable rational humanists who criticized the twentieth-century tendencies in higher education. They warned that the intellectual orientation of the German ideal, and vocational training had advanced to the point where general education of a more liberal character was suffering neglect and might soon disappear entirely (Brubacher \&Rudy, 1958). Summing up the different philosophies between the rational humanists and the reformers, Rudolph (1990) concluded that the distinction was "between a certain morality, a world of settled conviction, a regard for whole man, between these and a moral neutrality, a world of unsettled and tentative conviction, a regard for man as mind” (p.452).

In fact, the freedom given by elective curriculum did not achieve as much energetic and vigorous learning as Eliot expected. Studies showed that by the time Eliot retired, 55 percent of Harvard students were graduating having taken virtually nothing but elementary courses. More than 70 percent did not pursue any single field of knowledge in real depth (Bok, 2006). Further, the application of the elective system also contributed to students' knowledge fragmentation, in courses taken in isolation from one another, and the whole lacking any overall unity or design (Lucas, 1994).

Facing the alarming situation, some former advocates of the elective idea reversed themselves. Writing from retirement in 1908, Andrew Dickson White expressed his second thoughts on the matter, "there is certainly a widespread fear 
among many thinking men," he acknowledged, "that in our eagerness for ... new things in university education we have [too much] lost sight of certain valuable old things, the things in university education which used to be summed up under the word "culture." Having come almost full circle in his own thinking, White urged, "I believe that, whatever else we do, we must [not only] make men and women skillful in the various professions and avocations of life, but... [also] cultivate and bring out the best in them as men and woman (as cited in Lucas, 1994, p.211).

Perhaps World War I and the death of millions of young people spoke even louder in supporting this point of view. The beginning of twentieth century brought with it remarkable curricular reforms and experimentation that sought to restore integrity in liberal education, to seek a better balance between the elective system and rigid curriculum prescription, and to sustain both professional and liberal aims in America higher education, which marked the first revival of liberal education in history (Rudolph, 1990, Lucas, 1994).

\section{The First Revival of Liberal Education}

When Lawrence Lowell replaced Charles Eliot as president of Harvard in 1909, he introduced the concentration and distribution requirements as a compromise between the rigidity of the classical curriculum and the randomness of electives in Harvard (Bok, 2006). Every student was required to choose a major, or area of concentration, and study in depth within his or her major. In addition, all students needed to take a range of subjects in humanities, social sciences, and science areas in order to meet the distribution requirement. The academic major or concentration was to prevent students from taking a long series of introductory courses, and the 
distribution was intended to avoid overspecialization. However, taking courses from different departments did not guarantee breadth of study since the majority of courses were designed for a major or for preparing graduate study. Lowell's balancing act was less successful in practice than in theory (Boyer, 1987).

Another approach to restore liberal learning came in 1914 from President Alexander Meiklejohn of Amherst College. He introduced a survey course on social and economic institutions, a course in which students explored humanistic fields and gained an orientation to the larger world. Ten years later he was advocating two different types of general survey courses, one for first-year students and another as a "capstone" experience for fourth-year students. The latter served as the prototype for senior symposia introduced in 1924 at Reed College in Oregon. The stated purpose was to assist students to achieve a synthesis of the multiple historical, literary and scientific forces shaping contemporary society (Lucas, 1994).

Columbia University used the survey course approach to restore an intellectual and social foundation to the undergraduate curriculum. In the form of the famous “Contemporary Civilization” course, all entering freshman of 1919 were required to read from the primary sources and discuss the social historical forces that shaped the modern civilization. "There is a certain minimum of ... the [Western] intellectual and spiritual tradition that a man must experience and understand if he is to be called educated,” a faculty member explained (as cited in Lucas, 1994, p.213). By 1936 Columbia was also offering an integrative humanities sequence, then a survey of the sciences. Before long, the Columbia prototypes were being tried out on many other campuses. Extensive experimentations were followed as colleges and universities 
attempted to provided their students with the broad outlines of human knowledge through various synoptic surveys and introductory overview of the disciplines.

The most hotly debated experiment of this period was the University of Chicago plan introduced by President Robert Maynard Hutchins. He was not trying to find a balance between liberal education and professional training, nor did he intend to make any compromise between the elective and the prescribed curriculum. Instead, Hutchins sought to use Aristotle's metaphysics to unify the modern university and restore a classical liberal education. His vigorously written lectures comprised in The Higher Learning in America (1936), and Education for Freedom (1943) clarified both his theory and method.

Based on Aristotle's study of being, Hutchins (1943) proposed that the ideal of the United States should be "common good as determined in the light of reason" (p.59). Consequently, cultivating human intellect and establishing morals became the obligation of the educational system. He argued indisputably:

Wisdom and goodness are the end of human life. If you dispute this, you are at once entering upon a metaphysical controversy, for you are disputing about the nature of being and the nature of man...How can we consider man's destiny unless we ask what he is? How can we talk about preparing men for life unless we ask what the end of life may be? (Hutchins, 1943, p. 24) Having set up the goal, Hutchins suggested the primary object of higher education institutions should be cultivation of the intellectual virtues. For universities, he strongly recommended that they accomplish this goal by teaching the liberal arts-the "wisdom of the ages," the "Great Books.” Hutchins claimed "Education implies 
teaching, teaching implies knowledge. Knowledge is truth. The truth is everywhere the same” (Hutchins, 1936, p. 66). To Hutchins, pursuing intellect through the "Great Books” could restore moral values, integrate learning, and finally achieve the common good for society. Sciences were to take their place in liberal education, but Hutchins and his colleague Mortimer J. Adler insisted that the rational first principles had to take the priority and set the direction for science (Brubacher, 1958, p.287).

Hutchins (1943) fiercely attacked Eliot’s elective system:

Here the great criminal was Mr. Eliot, who as President of Harvard applied his genius, skill, and longevity to the task of robbing American youth of their cultural heritage. Since he held that there were no such things as good or bad subjects of study, his laudable effort to open the curriculum to good ones naturally led him to open it to bad ones and finally to destroy it altogether (p. 25).

Hutchins concluded that the curriculum elective, departmental specialization and vocational training were the culprits for thorough disorder and disintegration in higher learning; therefore they should be eliminated from colleges and universities (Hutchins, 1936, 1943)

Pragmatists, represented by John Dewey, immediately took issue with Hutchins' Higher Learning in America (Brubacher \& Rudy, 1958). First, Dewey would not accept the idea of establishing higher learning on Aristotle’s metaphysics, or the first principles, because such a choice implied authoritarianism. Authoritarianism posed a dangerous threat to intellectual freedom in higher education. 
Secondly, Dewey took a different view on truth from Hutchins'. Instead of making a commitment to the "wisdom of ages," pragmatists trusted in the scientific method of thought. And he believed that full truth is not known and we must be forever led by facts to revise our approximation of it. This is one of most important themes of pragmatism according to Kimball (1995). Applying scientific method, we must reach conclusions from tested data only, but that, since the data may be enlarged or the conclusions themselves combined with still other conclusion, we must hold them only tentatively. And we must be ready for change.

Third, Dewey and his colleague saw a different relationship between theory and practice from what Hutchins and Adler did. Confronted with a problem_scientific, economic, political or the like_they used theories as proposed lines of solution. Whether the theory was sound or not had to be tested in action. "Theory and practice thus went hand in hand, theory anticipating consequences and practice telling whether consequences corroborate theoretical expectations”(Brubacher \& Rudy, 1958, p.293). The method was the same, moreover, whether study was an inquiry into facts or values.

With the pragmatic principles, it is easy to understand why Dewey and his colleagues wanted to keep higher education closely attuned to current affairs, for it was there that problems arose and in that context that solutions had to be tested. Since many of thee problems came into a sharper focus in vocational life, it is easy to see how vocational concerns became a vital part of the pragmatist's curriculum. 


\section{The Second Revival of Liberal Education}

Obviously, in the twentieth century, American higher education faced the dilemma of choosing between two contrasting philosophies of education. These philosophies was described as "an aesthetically motivated mode of education for which the classics had set the pattern and a pragmatically motivated type for which the sciences set the style” (Brubacher \& Rudy, 1958, p.294).

The most notable effort to achieve a synthesis of these two contrasting philosophies of education was undertaken by a Harvard faculty committee during the Second World War. Its conclusion was published in a widely read report in 1945, General Education in a Free Society, commonly known as the Harvard Red Book. Tracing back to the root of western civilization, The Harvard faculty committee argued that the Greek idea of orderly society established on rationally constructed laws, abstract reasoning and debating was not achieved without skepticism, observation or the test of experience. It stated:

It is a mistake to identify the older Western culture with traditionalism. Classical antiquity handed on a working system of truth which relied on both reason and experience and was designed to provide a norm for civilized life. Its import was heightened and vastly intensified by its confluence with Christianity. But when, in its rigid systematization in the late Middle Ages, it lost touch with experience and individual inquiry, it violated its won nature and provoked the modernist revolt. The seeming opposition that resulted between traditionalism and modernism has been a tragedy for Western thought. Modernism rightly affirms the importance of inquiry and of relevance to 
experience. But as scholasticism ran the danger of becoming a system without vitality, so modernism runs the danger of achieving vitality without pattern (Harvard Red Book, 1945, p.49).

"The true task of education," the committee stated very succinctly, "is therefore so to reconcile the sense of pattern and direction deriving from heritage with the sense of experiment and innovation deriving from science that they may exist fruitfully together, as in varying degrees they have never ceased to do throughout Western history” (Harvard Red Book, p.50).

As to the approach of the reconciliation, the committee suggested a balance of "general education” and "special education” (Harvard Red Book, 1945, p. 51). The goal was to preserve general education in a society in which special education was necessary. Distinguishing between the two, general education was said to denote "that part of a student's whole education which looks first of all to his life as responsible human being and citizen; while the term special education indicates that part which looks to the students' competence in some occupation” (pg. 51). The former is "an organism, whole and integrated," whereas the latter is "an organ; a member designed to fulfill a particular function within a whole.” Both were held to be essential in a free society. Both were necessary for the development of the educated person-an individual capable of thinking effectively, communicating clearly, making relevant judgments and discriminating with care among values. Further, it clarified that "a general education is distinguished from special education, not by subject matter, but in terms of method and outlook, no matter what the field” (p.56). 
The Harvard Red Book emphasized that in a modern democratic society, all members were entitled to pursue their own dreams, while they should also share the responsibility for the management of the community. The challenge, therefore, was to preserve the ancient ideal of liberal education and extend it as far as possible to all members of society. Whatever shape or specific content it took; general education was indispensable because it spoke to the larger ends of personal, intellectual development and social service.

The Harvard Red Book (1945) also discussed "areas of knowledge” that could be taught in general education, and "traits of mind and characters" that knowledge could nourish and cultivate. The knowledge included science, social science, and the humanities. The traits of mind and character included the abilities "to think effectively, to communicate thought, to make relevant judgments, to discriminate among values” (p. 65). It cautioned against assuming that any one general education model would be workable for all colleges and universities. For Harvard, the report urged the institution toward a system whereby students would be required to complete at least one course each in the natural science, humanities and social studies, and an additional three courses of a general nature prior to or coincident with, advanced specialized training. A combination of survey courses and distribution requirements, monitored by a standing Committee of General Education, would safeguard the more general or common aims of undergraduate education in Harvard.

The Harvard Red Book of 1945 marked the second revival of liberal education. Many colleges and universities supported the Harvard plan. Especially, in 1947, a report released from the Truman Commission on Higher Education enthusiastically 
endorsed general education along the lines sketched out in the Harvard report. The Truman Commission claimed that general education updated liberal education to the modern society.

General education undertakes to redefine liberal education in terms of life's problems as men face them, to give it human orientation and social direction, to invest it with content that is directly relevant to the demands of contemporary society. General education is liberal education with its matter and method shifted from its original aristocratic intent to the service of democracy. General education seeks to extend to all men the benefits of an education that liberates (http://www.ed.uiuc.edu/courses/eol474/sp98/truman.html). Consequently, in 1947, the Truman Commission on Higher Education assigned liberal education to general education courses taken in the first two years of college. And its report provided federal sanction for the view that liberal/general education addresses the "non-vocational" aspects of learning. Thereafter, liberal education became virtually synonymous with general education (AAC\&U 2007, p.13), even though the Harvard Red Book (1945) cautioned not to equate general education with liberal education, and to avoid the argument from "specialists in various faculties," who were ready "to testify eloquently to the fact that their specialty, if properly taught, was in and by itself a liberal education” (p.ix).

Rudolph (1990) concluded that the movement of general education from Lawrence Lowell's distribution requirement in 1909 and Columbia's survey courses in 1919, to the celebrated Harvard report on the subject in 1945, "was an attempt to 
capture some of the sense of a continuing intellectual and spiritual heritage that had fallen victim to the elective principle... the movement marked a halt in the tendency toward specialization, as well as a new respect for the concept of education as the mark of a gentleman and a passport to human understanding” (p. 456 ).

But unfortunately, in the following two decades, the "space race” between the Soviets and the United States in the late 1950s and the social turmoil of the 1960s, diverted the cause of liberal education revival. The push for specialized competence and professionalism once again overtook the concern for general education. Student critics of education and their faculty allies argued for more diversity, pluralism and individual freedom. Liberal learning, when it was mentioned at all, was denounced as elitist and undemocratic (Lucas, 1994).

Once the collegiate turmoil in the 1960s was over, enthusiasm for liberal learning resurfaced again in the 1970s and continued through the 1980s and 1990s. An outpouring of books and articles on the subject, and a few new proposals came to epitomize the movement.

\section{Liberal Education Reconsidered}

The Carnegie Council on Policy Studies in Higher Education (1977) reported that between 1967 and 1974 general education requirements, as a percentage of undergraduate curricula, had dropped from 43 percent to 33.5 percent. "Today there is little consensus on what constitutes a liberal education,” the Council found, "and, as if by default, the choices have been left to the student.” General education, the report claimed, "is now a disaster area. It has been on the defensive and losing ground for 
more than 100 years” (p.11). Attempts at analyzing causes for the “disaster” dominated an ever-growing body of publications.

The most outspoken authors were those professors from the humanities. Allan Bloom's The Closing of the American Mind (1987) made the New York Times BestSeller list, whiles others’ publications (Bennett 1984; Hirsch, 1987; Bruce Wilshire, 1990; Reading, 1996) also shared the public popularity. Bloom (1987) declared: “There is no vision, nor is there a set of competing visions, of what an educated human being is” (p.337). In the words of Reading (1996) “The story of liberal education has lost its organizing center-has lost, that is, the idea of culture as both origin and goal, of the human sciences” (p. 10). Hirsch (1987) argued in Cultural Literacy, that progressive education had left Americans without a grasp of basic knowledge. Obviously, these humanists took the position that studying the humanities and transmitting culture should play a central role in liberal education. They were concerned that humanities were losing ground to the hard sciences as well as business in higher education, and they were disturbed by the fact that "a student can obtain a bachelor's degree from 75 percent of all American colleges and universities without having studied European history, from 72 percent without having studied American literature or history, and from 86 percent without having studied the civilization of classical Greece and Rome” (Bennett, 1984, p.2). However, even among the humanists, there was no agreement on what constituted a valuable humanities study. In fact, the argument between humanist right-wing, the traditionalists, and leftwing, the multiculturalists had led to an embroiled "cannon war" in the late 1980s and early 1990s (Lucas, 1994). Traditionalists, represented by Allen Bloom, Dinesh 
D’Souza, Roger Kimball and others, believed things had gone wrong in the 60s when universities took on the imperative to promote equality, stamp out racism, sexism and elitism, as well as war. The very ideals of truth and objectivity, along with conventional judgments of quality, were thought to be endangered by "political correctness," by making room for lesser works whose principal virtue seems to be that they were authored by women, African Americans or Third World Writers in the undergraduate curriculum (Allen Bloom 1987, D’Souza, 1991, Kimball 1990) Apparently, these traditionalists were in favor of centering the curriculum on classical works of literatures, such as the Great Books. This was reflected in the 1984 report, To reclaim a legacy by William J. Bennett, Secretary of the U.S. Department of Education. The report strongly recommended a common curriculum for general education with the humanities and western civilization at the core. The left camp of the "cannon war," represented by John Searle, a philosophy professor at Berkeley, criticized that general education had been dominated exclusively by the accomplishments of "dead white European males" to the virtual exclusion of all others, that the entire historical, literary and cultural "cannon” was Eurocentric and elitist. The left wing of the humanists insisted that humanities study in the curriculum of general education should include more works by women and members of minorities, a strong point illustrated in The Storm over University, in the New York Review of Book by John Searle 1990. Towards the end of the last century, it was generally agreed that the multiculturalists won the canon wars. Reading lists were broadened to include more works by women and minority writers, and most scholars consider that a positive development (Lucas, 1994). 
Reports from other commissions and committees such as Association of American Colleges in 1985 (AAC, 1985), and an extensive study issued by Ernest Boyer (1987), president of the Carnegie Foundation for the Advancement of Teaching, also identified the lack of overarching goals, rampant specialization, mindless fixations on marketplace measures, unbridled access, and faculty irresponsibility in maintaining quality and standards in undergraduate teaching as the major reasons that led to the subsequent collapse of structure and decline in the quality of undergraduate education. However, the reforms they proposed were different from the recommendations made in William J. Bennett’s 1984 report.

Instead of creating a common curriculum and identifying the subject matters in content, the AAC (1985) report recommended “nine experiences” or objectives as a framework to coherent undergraduate education. It stated "while learning cannot of course take place devoid of subject matter, how that subject matter is experienced is what concern us here (AAC, p.15). These "nine experiences" can be thought of as "skills" or as "ways of growing and understanding.” They are all thought to be basic to a coherent undergraduate education, including: (1) Inquiry, abstract logical thinking, critical analysis, (2) Literacy: writing, reading, speaking, and listening, (3) Understanding numerical data, (4) Historical conscious, (5) Science, (6) Values, (7) Art, (8) International and multicultural experiences, (9) Study in depth.

Boyer (1987) first identified the two essential goal of undergraduate education were to make students "become personally empowered and also committed to the common good" (p.69). To achieve these ends, Boyer (1987) suggested "the integrated core” as one approach to general education. He explained: "By integrated core we 
mean a program of general education that introduces students not only to essential knowledge, but also to connection across the disciplines, and in the end, to the application of knowledge to life beyond the campus" (p. 92). The "integrated core" was further translated into "seven areas of inquiry” as one suggested approach. These “seven areas of inquiry” included: (1) Language: the crucial connection, (2) Art: the esthetic experience, (3) Heritage: the living past, (4) Institution: the social web, (5) Nature: Ecology of the planet, (6) Work: the value of vocation, (7) Identity: the search for meaning. Each area of inquiry was explicitly explained and good examples of practice in different universities and colleges were introduced in Boyer's book. Proposals made by William Bennett, Ernest Boyer, and the American Association of Colleges in the 1980s are summarized in Table 1.

Table1

Proposals in the 1980s William Bennett 1984 Boyer 1987 AAC 1985 Common curriculum with humanities at the core. Distribution and major is not enough. Integrated core is recommended in general education program that Recommended reading list:

The Great Books introduces students not only to essential knowledge, but also to connections across the disciplines, and in the end, to the application of knowledge to life beyond the campus

Balance between breadth and depth

Original text Great Books (1) Language: the crucial
connection

(2) Nature: Ecology of the planet
Continuity $1^{\text {st }}$ to $4^{\text {th }}$ years
Subject matter is not an emphasis, how students experience them is the major concern.

Recommended nine experiences
(1) Inquiry, abstract logical thinking, critical analysis

(2) Literacy: writing, reading, speaking, and listening

(3) Understanding numerical data 
Table 1 continued

\begin{tabular}{lll}
\hline William Bennett 1984 & Boyer 1987 & AAC\&U 1985 \\
\hline $\begin{array}{l}\text { (3) Heritage: the living past } \\
\text { (4) Identity: the search for }\end{array}$ & (4) Historical consciousness \\
$\begin{array}{l}\text { meaning } \\
\text { (5) Art: the esthetic experience }\end{array}$ & (7) Art \\
& $\begin{array}{ll}\text { (6) Institution: the social web } & \text { (8) International and } \\
& \text { multicultural experiences } \\
\text { (7) Work: the value of } & \text { (9) Study in depth } \\
\text { vocation } & \end{array}$
\end{tabular}

The Synthesis of Liberal and Practical Learning

Despite the resurgence of liberal arts education and the hot debate over humanities studies, many supporters of postsecondary education in the same period of time asserted that an undergraduate curriculum still required the synthesis of liberal and practical learning (Boyer, 1987; Chickering, 1982; Durden, 2002; Green and Salem, 1988). Green \& Salem (1988) insisted that “any education that emphasizes knowledge for its own sake without also attending to the practical implications of that knowledge is irrelevant, if not sterile. Similarly, practical training devoid of any attention to the concerns of liberal learning (esthetics, history, ethics, and so on) is likely to be used mechanically without an informed consideration of its limits, and so is doomed to eventual failure even if not harm”(p. 2). Chickering (1982) pointed out that liberal education and preparation for work could not be separated, because those cognitive and interpersonal skills and motivations developed in liberal education were valuable in the workplace. Representing his committee, Boyer (1987) clearly stated 
"here is the heart of our curriculum proposal: rather than view the major as competing with general education, we are convinced that these two essential parts of bachelor should be intertwined" (p.110). Apparently, these educators were pointing to a new direction, a potential boon for both liberal arts and vocationally oriented education.

In the meantime, business leaders, governmental agencies, and professional associations in fields such as law, engineering and teaching, contended that college graduates lack the essential skills employers and other constituents expect of students upon completion of an undergraduate degree program (Van Horn, 1995). Not only did these groups demand that graduates possess career-specific knowledge, but also broad knowledge, and intellectual skills developed through liberal education (Curry \& Wergin, 1993). Consequently, integrating liberal education and vocationally oriented programs became a common theme in the reform proposals of the 1980s and 1990s.

A National Institute of Education report issued in 1984 recommended that course and curriculum requirements should not only contain career specific subject matter, but should also provide an opportunity for students to develop "capacities of analysis, problem solving, communication, and synthesis of knowledge” (p. 43). Professional programs of study should integrate knowledge and skills from a variety of disciplines to prepare students for a successful career.

The AAC (1991) report criticized the traditional design of curriculum and program structure that stresses discipline specific information and neglects to encourage integrating general education skills and synthesizing knowledge from other areas to add value to the learning process. It asserts that connection with other disciplines is a crucial goal of major fields of study: "Ultimately, the goal of the major 
should be the development for student' capacities for making connections and for generating their own translations and syntheses” (AAC, 1991, pg. 5).

AAC (1992) stated that integrating general education curriculum with programs of study curriculum and providing opportunities for students to apply knowledge and skills acquired in general education courses in the major fields of study are key elements of strong programs. The report strongly encourages assessment policy to include program reviews that "incorporate findings from assessment of student learning and examine direct examples of students' learning across the major as part of their overall review of program quality” (p. 2).

Engineering, medical and law professional organizations also maintained that the professional learning experience should be expanded to encourage students to develop critical thinking, problem solving, written and oral communication skills (Curry \& Wergin, 1993). The professionals agreed that practitioners must understand the technical and theoretical facets of the fields; however, technical knowledge alone is not sufficient to successfully practice in today's professional environments. Integrating skills and knowledge introduced in general education courses into the major fields of study allows students to develop professional expertise vital for career success.

Looking for the Results

After more than a decade of reform, a national survey of chief academic officers (CAOs), administrators of general education programs (AGE) and college students was conducted by Ratcliff, Johnson, La Nasa and Gaff and published in "The status of general education in the year 2000: summary of a national survey." 
One of the surprising findings was that, to most of the academic leaders, general education remained a high priority item on the majority of campuses, with 57 percent of the responding institutions currently conducting formal review of the general education program, and $43 \%$ planning a review in the next year. General education continues to comprise a significant portion of the baccalaureate degree. The average amounted to 37.6 percent of the baccalaureate curriculum, comparing 33.5 percent in 1974, and 37.9 percent in 1988. Between 1990 and 2000, state legislatures, state governing boards, and regional accrediting bodies had increased influence on general education requirements, especially at the public institutions, where 56 percent reported governing agencies influence. Their influence comes through the prescription of subjects to be taught, courses to be offered and/or student competencies to be achieved. GE requirements appear to be a primary target.

Survey results indicated that general education reforms of the past decade have resulted in a variety of new approaches that point toward the integration of general education and special education. These new approaches include freshman seminar, interdisciplinary courses, common learning experience, senior paper, thematic programs such as learning community, service learning, reflective essay, capstone, internship etc.

In spite of the high level of interest in general education from campus leaders and external sources, there is little evidence that academic leaders have made many advances in developing shared educational values and embedding them in the life of the institution. Student survey results showed that their attitudes towards general education did not change from 1990 to 2000. College students still see liberal 
education as the "non-vocational" or less marketable part of the curriculum. They still displayed a preference for specialized study, and they were unclear about the goals of general education. The value of liberal education is still mysterious to the public (Immerwahr \& Harvey, 1995; Hersh, 1997; Ratcliff et al. 2001).

A common model of general education structure is still the distribution requirement. When asked whether their programs had coherent sequences of course, the CAOs (chief academic officers) acknowledged that was the case very much or quite a bit only in thirty eight percent of the institutions investigated (Ratcliff, etc al. 2001).

Derek Bok, the former Harvard president in his 2006 book, Our Underachieving Colleges, also reported that the "overwhelming majority of all American colleges" are still using the "distribution" model for general education. He pointed out that simple distribution schemes could succeed only under certain conditions. First, faculties must be willing to spend considerable time advising students. Secondly, undergraduates must be highly motivated to secure a well-rounded education, and thirdly, special courses must be provided that are specifically designed to awaken curiosity and create enthusiasm in young people whose principal interests lie in other areas of the curriculum. However, these conditions hardly exist altogether in the majority of colleges and universities. Faculty advising still remains as a goal that is never fully achieved especially in public institutions with large undergraduate enrollments (Bok, 2006). Economic consideration remains prominent in the mind of prospective college students and their families (Pascarella, 2005; Harvey, 1995). Courses made it into the general education catalog because of different considerations. 
Some are introductory courses for students planning to major in a department; others are staple items in an established discipline; still others simply reflect the current interests of the professors teaching them. Of course, some of the courses may turn out to be ideally suited for awakening lasting interest in new field of knowledge or for acquainting students with intellectual works of enduring significance. "But such an outcome is more or less accidental, creating risks that distribution programs will force students to choose among courses that do not further the aims of general education at all” (Bok, 2006, p.260).

Under such conditions, the drawbacks of the simple distribution are apparent. The reason that the distribution requirement still remains the dominant means of general education is because it permits student choice, faculty autonomy and ease of administration. However, Bok pointed out that these administrative advantages should not be purchased at the expenses of intellectual defeat (Bok, 2006; Ratliff et al., 2001).

Other models that are presently practiced for general education program were also reported and analyzed by Derek Bok (2006). These include the Great Books, passionately advocated by Robert Hutchins and William Bennett, the survey courses initiated at Columbia University and the modes-of-inquiry approach. "None of them by itself offers an ideal solution. Each alternative has advantages that rival approaches cannot readily duplicate. Each has special disadvantages as well that are serious enough to make its adoption problematic" (p. 270), for this reason, some faculties respond by creating a hybrid model. The analyses of these five models are summarized in Table 2. 
Table 2

General (liberal) Education Models

General (liberal) education

models

The simple distribution

requirements: students

complete a certain number

of courses or credit hours

in each of three major

areas: the sciences, the

social sciences and the

humanities

The Great Books:

Study of finest books that civilization has produced in variety of fields through Socratic methods, through debating and discussions
Advantages

Disadvantages

Students can achieve some semblance of breadth with

minimal restraints in the

catalogue.

Faculty is not called upon

to create new courses or to

teach any subjects they do

not wish to teach.

College officials can

provide a general

education program without

incurring any new costs.

Students will understand

fundamental questions of

human existence, social

organization and the

natural and physical

environment.

It will refine students' tastes, deepen their insight into recurring interest in many field of human inquiry and experience.

It will create an enthusiastic common learning community, and provide a counterweight to the divisive tendencies of race, religion and class. increasingly diverse student body
Few of the offerings in the

GE catalog are designed for the goal of general education. Some are introductory course for liberal arts disciplines while over 60 percent of senior students are not majoring in. Others are staple items in an established discipline; still others simply reflect the current interests of the professors teaching them.

Difficult to make linkages and have coherence among courses developed and taught independently

Few faculty members have the training or aptitude to teach the Great Books.

Small section of the class demand more faculty members, more works. Faculty are occupied with other obligations, such as conducting graduate training, staffing concentration, and carrying on research

It has difficulty to attract students considering majority of students prefer a specialized education.

It is against the multiculturalists demand for diversity. 
Table 2 continued

\begin{tabular}{|c|c|c|}
\hline $\begin{array}{l}\text { General (liberal) education } \\
\text { models }\end{array}$ & Advantages & Disadvantages \\
\hline $\begin{array}{l}\text { The Modes-of-Inquiry: } \\
\text { Have students learn about } \\
\text { the principal ways in } \\
\text { which scholars and } \\
\text { scientists acquire } \\
\text { knowledge because the } \\
\text { volume of knowledge is far } \\
\text { too large and changes too } \\
\text { rapidly to justify a program } \\
\text { founded on a single set of } \\
\text { books or a fixed body of } \\
\text { essential information }\end{array}$ & $\begin{array}{l}\text { Students learn principal } \\
\text { methods of intellectual } \\
\text { inquiry. } \\
\text { It will lay a foundation that } \\
\text { enables students to keep on } \\
\text { learning throughout their } \\
\text { lives. }\end{array}$ & $\begin{array}{l}\text { It can easily become } \\
\text { superficial, lacking of } \\
\text { depth. } \\
\text { Large amount of facts and } \\
\text { information, quickly } \\
\text { learned and quickly } \\
\text { forgotten. } \\
\text { Faculty members unwilling } \\
\text { to teach introductory } \\
\text { courses covering vast } \\
\text { subjects; or many may not } \\
\text { feel competent to do so. } \\
\text { Too superficial to } \\
\text { accomplish much of value. } \\
\text { It emphasizes method over } \\
\text { other qualities of a } \\
\text { cultivated mind. Despite } \\
\text { all the controversy over the } \\
\text { existence of cannon, surely } \\
\text { some bodies of knowledge } \\
\text { are especially important to } \\
\text { an educated person and } \\
\text { some books are more } \\
\text { valuable than others. } \\
\text { If a faculty were to choose } \\
\text { courses simply by their } \\
\text { suitability for } \\
\text { demonstrating a particular } \\
\text { mode of thought, it could } \\
\text { produce a curriculum } \\
\text { conveying a hodgepodge } \\
\text { of information that omitted } \\
\text { many of the greatest works } \\
\text { of literature and social } \\
\text { thought. }\end{array}$ \\
\hline $\begin{array}{l}\text { Hybrid Models: } \\
\text { A combination of Great } \\
\text { Books, survey courses, } \\
\text { distribution requirements, } \\
\text { and the Modes-of-inquiry }\end{array}$ & $\begin{array}{l}\text { Gain attractive features } \\
\text { from different models }\end{array}$ & $\begin{array}{l}\text { Lose some valuable } \\
\text { features of each model. }\end{array}$ \\
\hline
\end{tabular}

Note: summarized from Bok (2006) 
Among these models, the least popular is the pure Great Books curriculum currently practiced at St. Johns College. The distribution requirement model "that calls for the least effort is the one most widely used in colleges across the country" (Bok, 2006, p.277).

Looking for direct evidence of student learning, researchers found that the vast majority of college graduates not only under performed in analytical and critical thinking, writing, and quantitative reasoning, but also lack civic engagement and ethical learning (Pascarella \& Terenzini, 1991; Astin, 1993; Bok, 2006). The most problematic area is within the so-called STEM disciplines: science, technology, engineering, and mathematics. According to the report from National Science Board 2004, the ratio of U.S. young adults with undergraduate degrees in these fields (around five percent) trails the rest of the developed world (twentieth place), well below Finland, France, Taiwan, South Korea, and the U.K. As to language and cultural literacy, research shows that only 10 percent of college graduates are competent (Adelman, 2004). Employers complained that only less than 25 percent of recent college graduate are well prepared for the workforce (AAC\&U, 2007). These indicators point to an ineffective general education system and an obsolete academic structure that urges a fundamental change.

Responding to this call, the Association of American Colleges and Universities launched the decade-long project, Liberal Education and America’s Promise (LEAP): Excellence for Everyone as a Nation Goes to College in 2005. The most recent report from LEAP, College learning for the New Global Century, AAC\&U (2007) provides a conceptual and pedagogical framework for educational renew and reform. It states: 
- In an era when knowledge is the key to the future, all students need the scope and depth of learning that will enable them to understand and navigate the dramatic forces-physical, cultural, economic, technological that directly affects the quality, character and perils of the world in which they live.

- In an economy where every industry-from the trades to advanced technology enterprises-is challenges to innovate or be displaced, all students need the kind of intellectual skills and capacities that enable them to get thing done in the world, at a high level of effectiveness.

- In a democracy that is diverse, globally engaged, and depends on citizen responsibility, all students need an informed concern for the larger good because nothing less will renew our fractured and diminished commons.

- In a world of daunting complexity, all students need practice in integrating and applying their learning to challenging questions and real-world problems

- In a period of relentless change, all students need the practice in integrating and applying their learning to challenge questions and real-world problems.

- In a period of relentless change, all students' need the kind of education that leads them to ask not just "how do we get this done?" but also "what is most worth doing?” (AAC\&U, 2007, p.13).

The world is setting higher expectations for today's college students. The AAC\&U (2007) urges this new recognition that every student-not just the fortunate few-will need wide-ranging and cross-disciplinary knowledge, higher-level skills, an active sense of personal and social responsibility, and a demonstrated ability to apply 
knowledge to complex problems. "The learning is best described as a liberal-and

liberating—education” (AAC\&U, 2007, p.11).

Liberal education is further clarified as a set Essential Learning Outcomes by

AAC\&U (2007) and they are listed in Table 3.

Table 3

The Essential Learning Outcomes Recommended by AAC\&U (2007)

Knowledge of human culture and the physical and natural World:

Beginning in school, and continuing at successively higher levels across their college studies, students should prepare for twenty-first-century challenges by gaining:

Through study in the sciences and mathematics, social sciences, humanities, histories, languages and the arts.

Focused by engagement with big questions, both contemporary and enduring.

Intellectual and practical skills, including:

1) Inquiry and analysis, critical and creative thinking

2) Written and oral communication

3) Quantitative literacy

4) Information literacy

5) Teamwork

6) Problem solving

Practiced extensively, across the curriculum, in the contest of progressively more challenging problems, projects and standards for performance

Personal and social responsibility, including:

7) Civic knowledge and engagement-local and global

8) Intercultural knowledge and competence

9) Ethical reasoning and action

10) Foundations and skills for lifelong learning

Anchored through active involvement with diverse communities and real-world challenges

Integrative learning, including

11) Synthesis and advanced accomplishment across general and specialized studies

Demonstrated through the application of knowledge, skills and responsibilities to new settings and complex problems. 
The redefined liberal education is neither delegated to general education programs, nor to discrete courses taken in liberal arts and science departments. Liberal education denominates any studies that help students to develop Essential Learning Outcomes. The first step to realize this goal, the AAC\&U recommends, is to re-map the liberal education. This requires extending the scope of liberal education from the conventional general education curriculum to all fields of studies, and from the first two years of college education to a full undergraduate experience. The re-mapping is illustrated in Table 4.

Table 4

Re-mapping Liberal Education

Liberal education in the $20^{\text {th }}$ century Liberal education in the $21^{\text {st }}$ century

\begin{tabular}{lll}
\hline What & An elite curriculum & A set of essential learning outcomes \\
& Non-vocational & A necessity for all students \\
An option for the fortunate &
\end{tabular}

Where Liberal arts colleges or colleges of arts and sciences in larger institutions

How Through studies in arts and sciences fields("the major") and or through general education in the initial years of college
All schools, community colleges, and universities; across all fields of study

Through studies across the entire educational continuum: school through college

Note: adapted from AAC\&U (2007)

By defining liberal education as set of Essential Learning Outcomes instead of courses and disciplines, and remapping it to the full undergraduate experience, AAC\&U (2007) provides a framework for universalizing liberal education across all types of institutions and uniting its philosophy with vocational oriented education. This proposal indicates a transformational change in liberal education. 


\section{Summary}

“The world is changing and liberal education must change too," the AAC\&U (2007) claimed (p.17). From a common curriculum of seven liberal arts to a set of “Essential Learning Outcomes,” from liberal arts and science disciplines to all area of studies, and from elite institutions for fortunate few to all types of colleges and universities for all students, the change in liberal education has been dramatic. This chapter reviews the salient research of the pivotal episodes and major conceptual transformations of American liberal education since its inception in the colonial period. There have been heated debates over the questions of what is a liberal education? What is the role of liberal education in undergraduate education? How should it be practiced? Should it require set courses, or provide student choice? Should the core curriculum offer common knowledge? Or should it nourish a way of learning? Should it focus on big questions, or on specialized exploration in a variety of disciplines? What is the relationship between liberal education and professional education? What is the relation between liberal education and discipline specialization? From the Yale Report to the Harvard Red Book, and beyond, the excursion demonstrates the flow from the classical model to a more secular and pragmatic approach, with a counter-current seeking to reduce the utilitarian and vocational tendencies and restore intellectual and cultural values in the revival of liberal education. The AAC\&U (2007) report represents the latest attempt to rejuvenate liberal education by widening its arc in the curriculum and connecting it to the national socio-economic agenda. 


\section{Data Source}

The data for this study came from the 2004 administration of the Faculty Survey of Student Engagement (http://nsse.iub.edu/pdf/fsse/faculty_survey_v4.pdf), an annual survey of faculty members at four-year colleges and universities across the country, designed to be a companion to the National Survey of Student Engagement (NSSE). Faculty respondents answered questions about their perceptions of college practice, and how they structured classroom activities and course assignments that prior research had connected to valuable learning outcomes (Chickering \& Gamson, 1987; Kuh, 2001, 2003; Pascarella \&Terenzini, 2005). FSSE results can be used to identify areas of strength as well as aspects of undergraduate education that may warrant attention (Laird, Niskodé, \& Kuh 2006). The FSSE 2004 data was used with permission from the Indiana University Center for Postsecondary Research.

The 2004 FSSE was completed by over 20,000 faculty members at 132 fouryear colleges and universities. Although not representative of all U.S. four-year institution, a wide cross-section of colleges and universities, which paralleled the national profile, used FSSE in 2004. Of the 132 four-year colleges and universities, 23\% were doctoral, $46 \%$ were master’s level, $12 \%$ were liberal arts and $17 \%$ were baccalaureate general. The national corresponding percentages of the institutions are: 18\% doctoral, 43\% masters, and 39\% baccalaureate general. These institutions were located in different regions across the country including Middle States, New England, North Central, North West, Southern, and Western. With public institutions of 55\% and private $45 \%$, both were well represented (Public national is $37 \%$, and private is 
63\%). Faculty academic characteristics such as disciplines and teaching experiences were also well represented. The response rate was calculated with each participating institution, and the average institutional response rate was $46 \%$ (http://fsse.iub.edu/pdf/2004_annual_report.pdf). Samples for our study consist of one fifth of the 20,000 cases randomly selected from the FSSE 2004 database.

\section{Research Design}

The research format involved seven independent variables and 11 dependent variables. These variables were presented in Table 3, and were described in the following paragraphs:

The first independent variable was Professional \& Applied vs. Others: This independent variable had two groups. The first one was composed of faculty members from the professional and applied fields, which included law, medicine, health sciences, pharmaceutical sciences, education, business and engineering etc. The other group (Others) had faculty members from arts \& humanities, biology, physical science, and social science. As an independent variable, these two groups were compared to determine whether there was any differences exist between these two on the dependent variables. (Detailed information about professional and applied fields was in attachment 2)

The second independent variable was Professional vs. Applied \& Others: This independent variable also had two groups. The first one was composed of faculty members only in professional fields, including law, medicine, health sciences, pharmaceutical sciences, etc. The other group had faculty members from education, business, engineering, arts \& humanities, biology, physical science, and social science. 
As the second independent variable, these two groups were compared to determine if there was any differences exist between them on the dependent variables.

The third independent variable was Eight Academic Disciplines, which had eight levels including (a) Arts \& Humanities, (b) Biology (c) Business, (d) Education, (e) Engineering, (f) Physical Science, (g) Social Science, and (h) Professional. This categorization was based on Biglan (1973a; 1973b) and Braxton \& Hargens (1996). As an independent variable, these eight disciplines were compared to determine if there was any differences exist among the disciplines on the dependent variables (detailed information about each discipline please see in attachment 1).

Carnegie Classification was the fourth independent variable. Institutions were categorized based on Carnegie Classification system (Carnegie Classification of Institution of Higher Education, 2000, Electronic data file, fourth revision, 2003). The Carnegie Foundation identified doctorate granting institutions as those that offer baccalaureate programs but were committed to graduate education through the doctorate. Master's colleges and universities were institutions that offer baccalaureate programs, but they were committed to graduate education through the master's. Baccalaureate colleges were primarily undergraduate institutions with a major emphasis on baccalaureate programs (Carnegie Classification of Institutions of Higher Education, 2000, Electronic data file, fourth revision, 2003). The six traditional Carnegie Classifications were condensed into three classifications for this study. The classifications were: (a) Doctoral (Doctorial/Research Universities-Extensive and Doctorial/Research Universities-Intensive), (b) Master’s (Master’s Colleges and 
Universities-I and Master's Colleges and Universities-II), and (c) Baccalaureate (Baccalaureate Colleges-Liberal Arts and Baccalaureate Colleges-General).

The type of institution was the fifth independent variable. Institutional types were categorized as (a) private, or (b) public.

The sixth independent variable was the accreditation region of the institutions. Accreditation regions were established by the Association of Schools and Colleges. They were (a) Middle States, (b) New England, (c) North Central, (d) North West, (e) Southern, and (f) Western.

In addition, teaching experiences accounted for the seventh independent variables. Teaching experience was grouped as (a) 1-4 year (b) 5-9 year (c) 10-14 year (d) 15 or more years.

Dependent variables were the essential learning outcomes that AAC\&U (2007) strongly recommended to promote in all disciplines, across four years of study and in all types of higher institutions. They were (1) Inquiry, Analysis, Critical and Creative Thinking, (2) Written and Oral Communication, (3) Quantitative Literacy (4) Information Literacy, (5) Team Work (6) Civic Knowledge and Engagement, (7) Intercultural Knowledge and Competence, (8) Ethical Reasoning and Action, (9) Foundation and Skills for Life Long Learning, (10) Integrative Learning, and (11) Problem Solving. 
Table 5

Variable Type and Variables

Independent Variables:

1. Professional \& Applied vs. Others.

2. Professional vs. Applied \& Others

3. Eight Academic Disciplines:

a. Arts \& Humanities

b. Biology

c. Business

d. Education

e. Engineering

f. Physical Science

g. Social Sciences

h. Professional

4. Carnegie Classification of higher Educational Institutions:
a. Doctoral
b. Master's
c. Baccalaureate

5. Institution status:

a. Public

b. Private

6. Accreditation region
a. Middle States
b. New England
c. North Central
d. North Western
e. Southern
f. Western

7. Teaching Experience
a. 1-4 year
b. 5-9 year
c. 10-14 year
d. 15 or more

Dependent Variables:

Essential Learning Outcomes AACU 2007

1. Inquiry and Analysis

Critical and Creative thinking

2. Written and Oral Communication

3. Quantitative Literacy

4. Information Literacy

5. Team Work

6. Civic Knowledge and Engagement

7. Intercultural Knowledge and Competence

8. Ethical Reasoning and Action (Table 5 continued next page) 
9. Foundation and Skills for Life Long Learning

10. Integrative Learning

11. Problem Solving.

Note: detailed information about disciplines, professional and applied fields, please see attachment 2

\section{Survey Instrument}

The survey instrument was FSSE 2004. It asked faculty members to answer a series of question about their expectations and in the context of a particular course they taught during the 2003-2004 academic year. Faculty respondents indicated their perspectives of college practices, and how much they structure their courses so that students learn and develop in areas such as writing clearly and effectively, working effectively with others, understanding people of other racial and ethic backgrounds, and developing a personal code of values and ethics. Responses to these items were measured using a four-point scale ranging from 1-4 ( 1 = very little, 2 = some, $3=$ quite a bit, 4 = very much). These items have been used by AAC\&U in an earlier report: Liberal Education Outcomes, a Preliminary Report on Student Achievement in College (AAC\&U, 2005), to determine how surveyed faculty foster AAC\&U recommended “Essential Learning Outcomes.” Table 6 indicates how AAC\&U (2005) matched up "Essential Learning Outcomes” with the FSSE items. FSSE items were also used to study how general education courses promote the essential learning outcomes recommended by AAC\&U (Laird, Niskodé, \& Kuh 2006). 
Table 6

Essential Learning Outcomes and the Corresponding Items in FSSE

Essential Learning Outcomes AAC\&U as dependent variables

1. Inquiry and analysis

Critical and creative thinking

2.Written and oral communication

3.Quantitative literacy

4. Information literacy

5. Team work

6. Civic knowledge and engagement

7. Intercultural knowledge and competence
Corresponding Items in FSSE

21c Thinking critically and analytically

21a Writing clearly and effectively

21b Speaking clearly and effectively

21d Analyzing quantitative problems

20d Making judgments about the value of information, arguments, or methods such as examine how others gathered and interpreted data and assessing the soundness of their conclusion.

5h Encourage students to use computers in their academic work

21e Using computing and information technology.

21f Working effectively with others.

1b Community service or volunteer work 34a Express an opinion about political or community issues in a public forum 34b Use media sources to stay informed abut local political or community issues 34c Participate in fundraising events 34d Attend a rally vigil or protest about an issue that is important to them 34e. Lead meetings or activities for local community organization or religious group

1f. Study abroad.

1e. Study a foreign language. 21i. Understanding people of other racial and ethnic backgrounds

5c. Encourage contact among students from different economic, social and racial or ethnic background 
Table 6 continued

8.Ethical reasoning and action

9. Foundation and skills for life long learning

10. Integrative learning

11. Problem solving 21k Developing a personal code of values and ethics

21h Understanding themselves

21g Learning effectively on their own

20e Applying theories or concepts to practical problems or in new situations 17d Put together ideas or concepts from different courses when completing assignments or during class discussions 17b Working on papers or projects that requires integrating ideas or information from various sources 20c Synthesizing and organizing ideas, information or experiences into new, more complex interpretation and relationship 1a Practicum, internship, field experience, co-op-experience

21j Solving complex real-world problems

\section{Data Analysis}

To determine the seven independent variables' effect on dependent variables of the 11 Essential Learning Outcomes (ELOs), 77 ANOVAs were first conducted to determine if there were any statistical significances exist among the seven treatment groups regarding each of the 11 ELOs. For example, one such ANOVA had the academic disciplines as the independent variable, and Quantitative Literacy (ELO \#3) as the dependent variable. Given the large size of the sample, we set the significance level at $p<.01$, rather than the traditional $p<.05$ to provide for a more conservative statistical testing. This adjustment to the level of statistical significant tends to reduce 
“Type I error,” which is defined as: "rejecting a null hypothesis when in fact it is true” (Hinkle, Wiersma \& Jurs, 2003, p.740).

For each of the statistical significant ELOs, effect size was calculated to determine the magnitude of differences among each of the treatment groups. Effect size was a way of quantifying the difference between two groups that had many advantages over the use of tests of statistical significance alone (Coe, 2002). Cohen (1977 \&1994) has pointed out that a statistically significant test does not necessarily connote an important finding of practical relevance. Using the effect in conjunction with the significance test gives a measure of practical importance within the context of the research study and the variables under consideration.

Within recent years, the American Psychological Association’s Task Force on Statistical Inference has recommended reporting effect sizes for published research. In fact numerous professional journals have policies that require reporting of effect size. Cohen (1977) defined effect size as “degree to which a phenomenon exists” (p.9). There were many ways to calculate effect sizes and they can be classified into two general families; standard differences and variance-accounted-for measures of strength of association (Snyder \& Lawson, 1993). Cohen (1965) provided guidelines for interpreting effect size. For details, see in Attachment 2.

For our analysis, standardized mean differences were calculated using regression analyses where the dependent measures first standardized. We reported two standardized mean differences (i.e., effect sizes with pooled standard deviation): one without controls and the other after controlling for the effects of the variables noted under each report. The effect size without controls represented the raw differences in 
emphasis on ELOs between the treatment group and the comparison group. The effect size with control represents how much of the difference was due to the fact of group difference and not to other characteristics of the faculty members (e.g., whether it is teaching experience, institution types of controls etc.). For example, to find out if faculty in different Carnegie Classifications put the same emphasis on "Integrative Learning," we computed the standardized mean scores of emphasizing "Integrative Learning" across the three types of institutions with and without control of other characteristics. The effect size with control represents how much of the difference was due to the fact of Carnegie Classification (Doctoral, Master's, and Baccalaureate), but not associated with other characteristics of the faculty members (e.g., disciplines, status of institutions, and teaching experience, and accreditation regions). 


\section{Chapter 4: Results}

The intention of the investigation was to determine the Essential Learning Outcomes (11ELOs) most strongly endorsed by faculty members with different teaching experiences, in particular academic disciplines, in Carnegie Classifications, institution types of controls and in particular accreditation regions. The results are presented as following to answer the seven research questions.

The analyses of variance (ANOVAs) relative to seven research questions are reported in Table 7. In that table, the independent variables related are faculties from (1) two groups of Professional \& Applied versus Others, (2) two groups of Professional versus Applied \& Others, (3) Professional (Professional, Applied, and Others all included), (4) three groups of Carnegie Classifications, (5) two groups of Institution Types of Control, (6) four groups of Teaching Experience, (7) six groups of Accreditation Regions.

The dependent variables are the 11 ELOs. They are (1) Inquiry, Analysis, Critical and Creative Thinking, (2) Written and Oral Communication, (3) Quantitative Literacy, (4) Information Literacy, (5) Team Work (6) Civic Knowledge and Engagement, (7) Intercultural Knowledge and Competence, (8) Ethical Reasoning and Action, (9) Foundation and Skills for Life Long Learning, (10) Integrative Learning, and (11) Problem Solving.

The results in Table 7 show the $F$ value and significance level for each of the ANOVAs (7 independent variables by 11 dependent variables, 77 ANOVAs in total). The significance level was set at $p<.01$, rather than the traditional $p<.05$ to provide for more conservative statistical testing. This adjustment to the level of statistical 
Table 7

ANOVA Tests

\begin{tabular}{|c|c|c|c|c|c|c|c|}
\hline & $\begin{array}{c}\text { Prof.\& } \\
\text { Applied } \\
\text { Vs. Others }\end{array}$ & $\begin{array}{l}\text { Prof. Vs. } \\
\text { Applied \& } \\
\text { Others }\end{array}$ & $\begin{array}{c}\text { Eight } \\
\text { Disciplines }\end{array}$ & $\begin{array}{c}\text { Carnegie } \\
\text { Classification }\end{array}$ & $\begin{array}{l}\text { Type of } \\
\text { Control }\end{array}$ & $\begin{array}{l}\text { Teaching } \\
\text { Experience }\end{array}$ & $\begin{array}{c}\text { Accreditation } \\
\text { Regions }\end{array}$ \\
\hline & F, Sig. & F, Sig. & F, Sig. & F, Sig. & F, Sig. & F, Sig. & F, Sig. \\
\hline Outcome 1 & $1.82 \mathrm{NS}$ & $2.05 \mathrm{NS}$ & $5.05 * * *$ & $2.93 \mathrm{NS}$ & $12.13 * * *$ & $3.53 \mathrm{NS}$ & 2.99NS \\
\hline Outcome 2 & $.64 N S$ & $0.00 \mathrm{NS}$ & $69.89 * * *$ & $5.23^{* *}$ & $31.61^{* * *}$ & 2.93NS & $6.55^{* * *}$ \\
\hline Outcome 3 & $41.00 * * *$ & $.89 \mathrm{NS}$ & $185.60 * * *$ & $3.62 \mathrm{NS}$ & $.01 \mathrm{NS}$ & $1.20 \mathrm{NS}$ & $4.44 * * *$ \\
\hline Outcome 4 & $201.17 * * *$ & $55.25 * * *$ & $33.42 * * *$ & 0.39NS & $5.68 \mathrm{NS}$ & $.18 N S$ & $8.23 * * *$ \\
\hline Outcome 5 & $134.99 * * *$ & $34.01^{* * *}$ & $38.82 * * *$ & $5.7 \mathrm{NS}$ & $5.18 \mathrm{NS}$ & $13.42^{* * *}$ & $1.14 \mathrm{NS}$ \\
\hline Outcome 6 & $.18 \mathrm{NS}$ & $37.33 * * *$ & $39.65^{* * *}$ & $12.48 * * *$ & $32.91^{* * *}$ & $2.64 \mathrm{NS}$ & $5.84 * * *$ \\
\hline Outcome 7 & $92.10 * * *$ & $.90 \mathrm{NS}$ & $139.31 * * *$ & $6.74 * *$ & $42.28 * * *$ & $1.10 \mathrm{NS}$ & $8.62 * * *$ \\
\hline Outcome 8 & $32.92 * * *$ & $61.38 * * *$ & $83.92 * * *$ & $5.07 * *$ & $20.26 * * *$ & $4.96 * *$ & $3.64 * *$ \\
\hline Outcome 9 & $14.35 * * *$ & $.08 \mathrm{NS}$ & $53.66 * * *$ & $1.54 \mathrm{NS}$ & $5.20 \mathrm{NS}$ & $1.38 \mathrm{NS}$ & $0.77 \mathrm{NS}$ \\
\hline Outcome 10 & $160.22 * * *$ & $80.55^{* * *}$ & $38.57 * * *$ & 4.59NS & 6.16NS & $8.34 * * *$ & $1.02 \mathrm{NS}$ \\
\hline Outcome 11 & $193.37 * * *$ & $33.14 * * *$ & $38.83 * * *$ & $6.58 * *$ & $.06 \mathrm{NS}$ & $5.22 \mathrm{NS}$ & $1.03 \mathrm{NS}$ \\
\hline
\end{tabular}


significance tends to reduce "Type I error,” which is defined as: "rejecting a null hypothesis when in fact it is true” (Hinkle, Wiersma, \& Jurs, 2003, p.740). Research Question 1

Are there significant differences between the two groups of Professional \& Applied versus other disciplines (Others) on faculty reports of emphasizing 11 ELOs?

The second column in Table 7 (p. 63) presents ANOVA results for Research Question 1. As may be noted, the two groups (Professional \& Applied vs. Others) differed significantly (at least $p<.01$ ) on eight dependent variables (or Outcomes), which include Outcome (3) Quantitative literacy, (4) Information Literacy, (5) Team Work, (7) Intercultural Knowledge and Competence, (8) Ethical Reasoning and Action, (9) Foundation and Skills for Life Long Learning, (10) Integrative Learning, (11) Problem Solving, while there is no statistical significance between these two groups' emphasizing on dependent variables (or outcomes) of (1) Inquiry, Analysis, Critical and Creative Thinking, (2) Written and Oral Communication, and (6) Civic Knowledge and Engagement.

To determine the magnitude of the difference between the two faculty groups (Professional \& Applied vs. Others) on each of the eight significant dependent variables (Outcomes of 3, 4, 5, 7, 8, 9, 10, 11), effect sizes (ES) were calculated using regression analyses where the dependent measures were first standardized. Tables 8 through 15 present the results with Mean, Standardized Deviation (SD), Number of Participants $(N)$, and ES for each group. The effect size without control represents the raw difference in emphasis on each of the above dependent variables between the two 
groups. The effect size with control represents how much of the difference is due to the fact of the group difference and not to other characteristics of the faculty members (e.g., Teaching Experience, Accreditation Regions, etc). For each dependent variable (Outcome), the control variables are different. They were chosen based on the ANOVA results shown in Table 7 (p.64).

For Outcome (3) Quantitative Literacy, Table 8 indicates that faculty from Others emphasize less than faculty members from Professional \& Applied areas. Mean score for each is 2.27 and 2.56 respectively. The mean of faculty from Others is .23 SD below the mean of faculty from Professional and Applied areas both without and with control (ES without control $=-.23, p<.001$, ES with control $=-$. 23, $p<$ .001). Introducing the control variables doesn’t change the effect size. This means accreditation region’s influence doesn't make noticeable difference in magnitude between these two groups.

Table 8

Professional and Applied vs. Others in Emphasis on Quantitative Literacy (Outcome 3)

\begin{tabular}{lccccccc}
\hline Groups & $\mathrm{N}$ & MEAN & SD & Sig. & $\begin{array}{c}\text { ES } \\
\text { with/o }\end{array}$ & Sig. & $\begin{array}{c}\text { ES with } \\
\text { Control }\end{array}$ \\
\hline $\begin{array}{l}\text { Others } \\
\text { Prof. \& }\end{array}$ & 2219 & 2.27 & 1.23 & $* * *$ & -0.23 & $* * *$ & -0.23 \\
$\begin{array}{l}\text { Applied } \\
\text { Total }\end{array}$ & 1122 & 2.56 & 1.19 & & & & \\
$\begin{array}{l}\text { Note: *** }<.01, * * * p<001 \\
\text { Control variables: Accreditation Region. }\end{array}$ & & & & & & \\
\end{tabular}

For Outcome (4) Information Literacy, Table 9 indicates faculty from Others emphasize less than faculty from Professional \& Applied areas, and mean score for each group is 2.85, and 3.15 respectively. The effect size without control $\mathrm{ES}=-.50, p$ $<.001$, which indicate the mean of faculty from Others is half SD below the mean of 
faculty from Professional \& Applied areas. Introducing control variables did not change the effect size.

Table 9

Professional \& Applied vs. Others in Emphasis on Information Literacy (Outcome 4)

\begin{tabular}{|c|c|c|c|c|c|c|c|}
\hline Groups & $\mathrm{N}$ & MEAN & SD & Sig. & $\begin{array}{c}\text { ES } \\
\text { with/o }\end{array}$ & Sig. & $\begin{array}{l}\text { ES with } \\
\text { Control }\end{array}$ \\
\hline Others & 2270 & 2.85 & 0.60 & $* * *$ & -0.50 & $* * *$ & -0.50 \\
\hline $\begin{array}{l}\text { Prof. \& } \\
\text { Applied }\end{array}$ & 1172 & 3.15 & 0.58 & & 0.00 & & \\
\hline Total & 3442 & 3.05 & 0.59 & & & & \\
\hline
\end{tabular}

For Outcome (5) Team Work, Table 10 shows that faculty from Others emphasize less than faculty from Professional \& Applied areas. Mean for each group is 2.54, and 2.97 respectively. Effect size without control ES $=-.42, \mathrm{p}<.001$, which indicates the mean of faculty from other areas is .42 SD below mean of faculty from Professional \& Applied. Effect size with control is the same as without control.

Table 10 Professional \& Applied vs. Others in Emphasis on Team Work (Outcome 5)

\begin{tabular}{|c|c|c|c|c|c|c|c|}
\hline Groups & $\mathrm{N}$ & MEAN & SD & Sig. & $\begin{array}{c}\mathrm{ES} \\
\text { with/o }\end{array}$ & Sig. & $\begin{array}{l}\text { ES with } \\
\text { Control }\end{array}$ \\
\hline Others & 2242 & 2.54 & 1.04 & $* * *$ & -0.42 & $* * *$ & -0.42 \\
\hline $\begin{array}{l}\text { Prof. \& } \\
\text { Applied }\end{array}$ & 1126 & 2.97 & 0.97 & & 0.00 & & \\
\hline Total & 3368 & 2.82 & 0.97 & & & & \\
\hline
\end{tabular}

For Outcome (7) Intercultural Knowledge and Competence, Table 11 shows that faculty from Others emphasize more than faculty from Professional \& Applied areas. Mean for each group is 2.57 and 2.34 respectively. Effect size without control is 
$\mathrm{ES}=.34, p<.001$, which indicates the mean of faculty from other areas is $.34 \mathrm{SD}$ above mean of faculty from Professional \& Applied areas. Effect size with control = $.32, p<.001$. Introducing control variables slightly decreased the effect size.

Table 11

Professional \& Applied vs. Others in Emphasis on Intercultural Knowledge and Competence (Outcome 7)

\begin{tabular}{|c|c|c|c|c|c|c|c|}
\hline Groups & $\mathrm{N}$ & MEAN & SD & Sig. & $\begin{array}{c}\text { ES } \\
\text { with/o }\end{array}$ & Sig. & $\begin{array}{l}\text { ES with } \\
\text { Control }\end{array}$ \\
\hline Others & 2273 & 2.57 & 0.67 & $* * *$ & 0.34 & $* * *$ & 0.32 \\
\hline $\begin{array}{l}\text { Prof. \& } \\
\text { Applied }\end{array}$ & 1173 & 2.34 & 0.63 & & 0.00 & & \\
\hline Total & 3446 & 2.39 & 0.68 & & & & \\
\hline
\end{tabular}

For Outcome (8) Ethical Reasoning and Action, Table 12 shows that faculty from Others emphasize less than faculty from Professional \& Applied areas. Mean for each is 2.47 and 2.67. Effect size without control $=-.21, p<.001$, which indicates the mean score of faculty from Others is .21 SD below the mean of faculty from Professional \& Applied. Effect size with control is ES $=-.23, p<.001$. Introducing control variables slightly increased the effect size.

Table 12

Professional \& Applied vs. Others in Emphasis on Ethical Reasoning and Action (Outcome 8)

\begin{tabular}{lccccccc}
\hline Groups & $\mathrm{N}$ & MEAN & SD & Sig. & $\begin{array}{c}\text { ES } \\
\text { with/o }\end{array}$ & Sig. & $\begin{array}{c}\text { ES with } \\
\text { Control }\end{array}$ \\
\hline $\begin{array}{l}\text { Others } \\
\begin{array}{l}\text { Prof. \& } \\
\text { Applied }\end{array}\end{array}$ & 2243 & 2.47 & 0.95 & $* * *$ & -0.21 & $* * *$ & -0.23 \\
$\begin{array}{l}\text { Total } \\
\text { Note. } *_{p}<.01, * * * p<.001\end{array}$ & 2.67 & 0.91 & & 0.00 & & \\
Control variables: Carnegie classification, institution type of control, teaching experience, accreditation Region. &
\end{tabular}


For Outcome (9) Foundations and Skills for Life Long Learning, Table 13 shows that faculty from Others emphasize more than faculty from Professional \& Applied. Mean for each is 3.30 and 3.21 respectively. Effect size without control is ES $=.14, p<.001$, which indicates the mean of faculty from Others is $.14 \mathrm{SD}$ above the mean of faculty from Professional \& Applied, although the size of effect is modest.

Table 13

Professional \& Applied vs. Others in Emphasis on Foundations and Skills for Life Long Learning (Outcome 9)

\begin{tabular}{lccccccc}
\hline Groups & $\mathrm{N}$ & MEAN & SD & Sig. & $\begin{array}{c}\text { ES } \\
\text { with/o }\end{array}$ & Sig. & $\begin{array}{c}\text { ES with } \\
\text { Control }\end{array}$ \\
\hline $\begin{array}{l}\text { Others } \\
\text { Prof. \& }\end{array}$ & 2244 & 3.30 & 0.69 & $* * *$ & 0.14 & & \\
$\begin{array}{l}\text { Applied } \\
\text { Total }\end{array}$ & 1126 & 3.21 & 0.71 & & 0.00 & & \\
\hline Note. ${ }^{* *} p<.01,{ }^{* * *} p<.001$ & 3370 & 3.22 & 0.70 & & & \\
\end{tabular}

For Outcome (10) Integrative Learning, Table 14 shows that faculty from Others emphasize less than faculty from Professional \& Applied. Mean for each is 3.05 and 3.32 respectively. Effect size without control $=-.45, p<.001$, which indicates that the mean of faculty from Others is .45 SD below the mean of faculty from Professional \& Applied. Effect size with control is the same.

Table 14

Professional \& Applied vs. Others in Emphasis on Integrative Learning (Outcome10)

\begin{tabular}{lccccccc}
\hline Groups & $\mathrm{N}$ & MEAN & SD & Sig. & $\begin{array}{c}\text { ES } \\
\text { with/o }\end{array}$ & Sig. & $\begin{array}{c}\text { ES with } \\
\text { Control }\end{array}$ \\
\hline Others & 2273 & 3.05 & 0.60 & $* * *$ & -0.45 & $* * *$ & -0.45 \\
$\begin{array}{l}\text { Prof. \& } \\
\text { Applied }\end{array}$ & 1173 & 3.32 & 0.55 & & 0.00 & & \\
$\begin{array}{l}\text { Total } \\
\text { Note. }{ }^{* *} p<.01, * * * p<001\end{array}$ & 3446 & 3.24 & 0.58 & & & \\
Control variables: Teaching experience.
\end{tabular}


For Outcome (11), Problem Solving, Table 15 shows that faculty from Others emphasize less than faculty from Professional \& Applied. Mean for each is 2.65 and 3.14 respectively. Effect size without control is ES $=-.50, p<.001$, which indicates that the mean of faculty from Others is half SD below mean of faculty from Professional \& Applied. Effect size with control is the same as effect size without control.

Table 15

Professional \& Applied vs. Others in Emphasis on Problem Solving (Outcome 11)

\begin{tabular}{lccccccc} 
Groups & $\mathrm{N}$ & MEAN & SD & Sig. & $\begin{array}{c}\text { ES } \\
\text { with/o }\end{array}$ & Sig. & $\begin{array}{c}\text { ES with } \\
\text { Control }\end{array}$ \\
\hline Others & 2228 & 2.65 & 1.01 & $* * *$ & -0.50 & $* * *$ & -0.50 \\
$\begin{array}{l}\text { Prof. \& } \\
\text { Applied }\end{array}$ & 1121 & 3.14 & 0.89 & & 0.00 & & \\
$\begin{array}{l}\text { Total } \\
\text { Note: } * *<<.01, * * * p<001\end{array}$ & 3349 & 2.99 & 0.93 & & & \\
Control variables: Carnegie Classification & & & & & &
\end{tabular}

Out of the 11 recommended ELOs, the two groups' emphasis (Others vs. Professional \& Applied) differed significantly on 8 Outcomes (Table 7, Column 2, p.64). Out of these eight significant Outcomes, faculty from Others emphasize less than faculty from Professional \& Applied on six Outcomes (Outcome 3, 4, 5, 8, 10, \&11), and Others only emphasize more on two Outcomes than Professional \& Applied (Outcome $7 \&$ 9). Effect size ranges from .14 to .50.

Research Question 2

Are there significant differences between the two groups of Professional versus Applied \&Others’ faculty reports on emphasizing 11 ELOs? 
The third column in Table 7 presents ANOVA results for question 2. As may be noted, the two groups differed significantly (at least $p<.01$ ) on six dependent variables (or Outcomes), which include Outcome (4) Information Literacy, (5) Team Work (6) Civic Knowledge and Engagement, (8) Ethical Reasoning and Action, (10) Integrative Learning, (11) Problem Solving, while there is no statistical significance between these two groups' emphasizing on dependent variables (or outcomes) of (1) Inquiry, Analysis, Critical and Creative Thinking, (2) Written and Oral communication, (3) Quantitative Literacy, (7) Intercultural Knowledge and Competence (9) Foundation and Skills for Life Long Learning.

To determine the magnitude difference between these two groups' emphasis on the six significant dependent variables (Outcome 4, 5, 6, 8, 10, \&11, Table 7, p.64), Effect sizes (ES) with and without control were calculated using regression where the dependent measures were first standardized. Table 16 through 21 present the results with Mean, SD (SD), Number of Participants (N), and ES for each group.

For Outcome (4) Information Literacy, Table 16 shows that faculty from Applied \& Others emphasize less than faculty from Professional areas. The mean for each group is 2.93 and 3.19 respectively. The effect size without control ES $=-.43, p$ $<.001$, which indicates the mean of faculty from Applied \& Others is .43 SD below the mean of faculty of Professionals. The effect size with control is the same as without control, and partial out the influence of control variable does not make noticeable difference in the size of the effect. 
Table 16

Professional vs. Applied \&Others in Emphasis on Information Literacy (Outcome 4)

\begin{tabular}{lccccccc}
\hline Groups & $\mathrm{N}$ & MEAN & SD & Sig. & $\begin{array}{c}\text { ES } \\
\text { with/o }\end{array}$ & Sig. & $\begin{array}{c}\text { ES with } \\
\text { Control }\end{array}$ \\
\hline $\begin{array}{l}\text { Applied } \\
\text { \&Others }\end{array}$ & 3120 & 2.93 & 0.60 & $* * *$ & -0.43 & $* * *$ & -0.43 \\
$\begin{array}{l}\text { Prof. } \\
322\end{array}$ & 3.19 & 0.58 & & & &
\end{tabular}

Table 16 continued

Total $\quad 3442 \quad 3.06 \quad 0.63$

Note. ${ }^{* *} p<.01, * * * p<.001$

Control variables: Accreditation region.

For Outcome (5) Team Work, Table 17 shows that faculty from Applied \& Others emphasize less than faculty from Professional areas. The mean for each group is 2.65 and 3.01 respectively. The effect size without control is ES $=-.35, p<.001$, which indicates the mean of faculty from Applied \& Others is .35 SD below the mean of faculty for Professional areas. Effect size with control is ES $=-.36, p<.001$. Partial out the influence of Teaching Experience, the control variable, slightly increase the size of the effect between these two groups.

Table 17

Professional vs. Applied \&Others in Emphasis on Team Work (Outcome 5)

\begin{tabular}{lccccccc}
\hline Groups & $\mathrm{N}$ & MEAN & SD & Sig. & $\begin{array}{c}\text { ES } \\
\text { with/o }\end{array}$ & Sig. & $\begin{array}{c}\text { ES with } \\
\text { Control }\end{array}$ \\
\hline $\begin{array}{l}\text { Applied } \\
\text { \&Others }\end{array}$ & 3069 & 2.65 & 1.04 & $* * *$ & -0.35 & $* * *$ & -0.36 \\
$\begin{array}{l}\text { Prof. } \\
\text { Total }\end{array}$ & 303 & 3.01 & 0.98 & & 0.00 & & \\
$\begin{array}{l}\text { Note. }{ }^{* *} p<.01, * * * p<.001 \\
\text { Control variables: Teaching experience. }\end{array}$ & 2.83 & 1.00 & & & & \\
\end{tabular}

For Outcome (6) Civic Knowledge and Engagement, Table 18 shows that faculty from Applied \& Others emphasize less than faculty from Professional areas. 
The mean for each group is 2.34 and 2.59 respectively. The effect size without control ES $=-.35, p<.001$, which indicates the mean of faculty from Applied \& Others is .28 SD below the mean of faculty from Professional areas. Effect size with control is ES = $-.39, p<.001$. Partial out the control variables influence, the size of the effect, the magnitude difference between these two groups increased.

Table 18

Professional vs. Applied \&Others in Emphasis on Civic Knowledge and Engagement (Outcome 6)

\begin{tabular}{lccccccc}
\hline Groups & $\mathrm{N}$ & MEAN & SD & Sig. & $\begin{array}{c}\text { ES } \\
\text { with/o }\end{array}$ & Sig. & $\begin{array}{c}\text { ES with } \\
\text { Control }\end{array}$ \\
\hline $\begin{array}{l}\text { Applied } \\
\text { \&Others }\end{array}$ & 3123 & 2.34 & 0.70 & $* * *$ & -0.35 & $* * *$ & -0.39 \\
$\begin{array}{l}\text { Prof. } \\
\text { Total }\end{array}$ & 323 & 2.59 & 0.67 & & 0.00 & & \\
$\begin{array}{l}\text { Note. **p<.01, *** }<<.001 \\
\text { Control variables: Carnegie classification, institution type of control, accreditation region. }\end{array}$
\end{tabular}

For Outcome (8) Ethical Reasoning, Table 19 presents that faculty in Applied \& Others emphasize less than faculty from Professional areas too. The mean for each group is 2.50 and 2.94 respectively. The effect size without control is ES $=-.47, p<$ .001 , which indicates the mean of faculty from other areas is $.47 \mathrm{SD}$ below mean of faculty in Professional areas. The effect size with control is ES $=-.48, p<.001$. Introducing the control variables increased the effect size. 
Table 19

Professional vs. Applied \&Others in Emphasis on Ethical Reasoning and Action (Outcome 8)

\begin{tabular}{lccccccc} 
Groups & $\mathrm{N}$ & MEAN & SD & Sig. & $\begin{array}{c}\text { ES } \\
\text { with/o }\end{array}$ & Sig. & $\begin{array}{c}\text { ES with } \\
\text { Control }\end{array}$ \\
\hline $\begin{array}{l}\text { Applied } \\
\text { \&Others }\end{array}$ & 3069 & 2.50 & 0.92 & $* * *$ & -0.47 & $* * *$ & -0.48 \\
$\begin{array}{l}\text { Prof. } \\
\text { Total }\end{array}$ & 304 & 2.94 & 0.88 & & 0.00 & & \\
$\begin{array}{l}\text { Note. }{ }^{* *} p<.01, * * * p<.001 \\
\text { Control variables: Carnegie classification, institution type of control, teaching experience, accreditation region }\end{array}$
\end{tabular}

For Outcome (10) Integrative Learning, Table 20 presents that faculty in Applied \& Others emphasize less than faculty from Professional areas too. The mean for each is 3.11 and 3.42. The effect size without control is ES $=-.52, p<.001$, which indicates the mean of faculty in Applied \& Others is .52 SD below the mean of faculty in the Professional areas. Effect size with control is the same as effect size without control $=-.52, p<.001$.

Table 20

Professional vs. Applied \&Others in Emphasis on Integrative Learning (Outcome 10)

\begin{tabular}{lccccccc}
\hline Groups & $\mathrm{N}$ & MEAN & SD & Sig. & $\begin{array}{c}\text { ES } \\
\text { with/o }\end{array}$ & Sig. & $\begin{array}{c}\text { ES with } \\
\text { Control }\end{array}$ \\
\hline $\begin{array}{l}\text { Applied } \\
\text { \&Others }\end{array}$ & 3123 & 3.11 & 0.58 & $* * *$ & -0.52 & $* * *$ & -0.52 \\
$\begin{array}{l}\text { Prof. } \\
\text { Total }\end{array}$ & 323 & 3.42 & 0.54 & & 0.00 & & \\
& 3446 & 3.27 & 0.63 & & & &
\end{tabular}

Note. ${ }^{* *} p<.01,{ }^{* * *} p<.001$

Control variables: teaching experience.

For Outcome (11) Problem Solving, Table 21 shows that faculty from Applied \& Others emphasize less than faculty from the Professional areas. The mean for each group is 2.78 and 3.13 respectively. The effect size without control is $\mathrm{ES}=-.35, p<$ 
.001 , which is to say that the mean of faculty from Applied \& Others is .35 SD below the mean of faculty in Professional areas. Effect size with control make no noticeable difference in the size of effect or difference in magnitude between these two groups.

Table 21

Professional vs. Applied \&Others in Emphasis on Problem Solving (Outcome11)

\begin{tabular}{lccccccc}
\hline Groups & $\mathrm{N}$ & MEAN & SD & Sig. & $\begin{array}{c}\text { ES } \\
\text { with/o }\end{array}$ & Sig. & $\begin{array}{c}\text { ES with } \\
\text { Control }\end{array}$ \\
\hline $\begin{array}{l}\text { Applied } \\
\text { \&Others }\end{array}$ & 3046 & 2.78 & 1.01 & $* * *$ & -0.35 & $* * *$ & -0.35 \\
$\begin{array}{l}\text { Prof. } \\
\text { Total }\end{array}$ & 303 & 3.13 & 0.93 & & 0.00 & & \\
$\begin{array}{l}\text { Note. }{ }^{* *}<<.01, * * * p<.001 \\
\text { Control variables: Carnegie classification. }\end{array}$ & & & & & & & \\
\end{tabular}

It is interesting to notice that out of the 11 recommended ELOs, the two groups of faculty (Applied \& Others vs. Professionals) differed significantly on six Outcomes (Outcome 4, 5, 6, 8, 10, \&11, Table 7, p.64). Effect size calculations indicate that, out of these six Outcomes, faculty in the Professional emphasizes more on all of them than Applied \& Others. The Effect size ranges from 0.35-0.52.

Research Question 3

Are there any significant differences between eight academic disciplines (include Professional, Applied \& Others) on faculty reports of emphasizing 11 ELOs?

The forth column in Table 7 presents ANOVA results for question 3. As maybe noted, the eight groups of faculty from eight academic disciplines differed significantly (at least $p<.01$ ) on all 11 dependent variables (or Outcomes), which include Outcome (1) Inquiry, Analysis, Critical and Creative Thinking, (2) Written and Oral Communication, (3) Quantitative Literacy, (4) Information Literacy, (5) 
Team Work (6) Civic Knowledge and Engagement, (7) Intercultural Knowledge and Competence, (8) Ethical Reasoning and Action, (9) Foundation and Skills for Life Long Learning, (10) Integrative Learning, and (11) Problem Solving.

To determine the magnitude difference among these eight discipline groups of faculty’s emphasis on the 11 dependent variables (Outcome 1-11, Table 7, p.64), Professional was chosen as a comparison group, and standardized mean difference from Professional, the effect size (ES) with and without control were calculated using regression where the dependent measures were first standardized. Tables 23 through 33 present the results with Mean, SD (SD), Number of Participants (N), and ES for each groups compared with Professional.

For the emphasis on Outcome (1) Inquiry, analysis, critical and creative thinking, Table 22 shows the average for eight disciplines is 3.55, comparatively high. Ranking from high to low, the eight disciplines are listed as Arts and Humanity 3.63, Professional 3.62, Engineering 3.60, Physical science 3.58, Social Science 3.56, Education 3.51, Business 3.50, and Biology 3.38. Compared to Professionals, the mean of Biology is .37 SD below without control and .38 SD below with control (ES without control $=-.37, p<.001$, ES with control $=-.38, p<.001)$, the mean of Business is .19 SD below without control and .20 SD below with control (ES without control $=-.19, p<.001$, ES with control $=-.20, p<.001)$. These are the appreciable effect sizes compared with Professional. The other disciplines' effect sizes are trivial. 
Table 22

Eight Discipline Difference in Emphasis on Inquiry and Analysis, Critical and Creative Thinking (Outcome 1)

\begin{tabular}{|c|c|c|c|c|c|c|c|}
\hline $\begin{array}{l}8 \text { Academic } \\
\text { Discipline }\end{array}$ & $\mathrm{N}$ & MEAN & SD & Sig. & $\begin{array}{l}\text { ES w/o } \\
\text { Control }\end{array}$ & Sig. & $\begin{array}{l}\text { ES with } \\
\text { control }\end{array}$ \\
\hline $\begin{array}{l}\text { Arts \& } \\
\text { Humanities }\end{array}$ & 1062 & 3.63 & 0.63 & NS & 0.01 & NS & 0.01 \\
\hline Biology & 206 & 3.38 & 0.72 & $* * *$ & -0.37 & $* * *$ & -0.38 \\
\hline Business & 369 & 3.50 & 0.64 & $* *$ & -0.19 & $* *$ & -0.20 \\
\hline Education & 288 & 3.51 & 0.65 & NS & -0.17 & NS & -0.17 \\
\hline Engineering & 161 & 3.60 & 0.56 & NS & -0.04 & NS & -0.03 \\
\hline $\begin{array}{l}\text { Physical } \\
\text { Sciences }\end{array}$ & 449 & 3.58 & 0.62 & NS & -0.06 & NS & -0.07 \\
\hline Social Science & 517 & 3.56 & 0.62 & NS & -0.09 & NS & -0.10 \\
\hline Professional & 302 & 3.62 & 0.63 & & 0.00 & & 0.00 \\
\hline Total & 3354 & 3.55 & & & & & \\
\hline
\end{tabular}


Table 23

Eight Academic Discipline Difference in Emphasis on Written and Oral Communication (Outcome2)

\begin{tabular}{|c|c|c|c|c|c|c|c|}
\hline $\begin{array}{l}8 \text { Academic } \\
\text { Discipline }\end{array}$ & $\mathrm{N}$ & MEAN & SD & Sig. & $\begin{array}{l}\text { ES w/o } \\
\text { Control }\end{array}$ & Sig. & $\begin{array}{c}\text { ES with } \\
\text { control }\end{array}$ \\
\hline $\begin{array}{l}\text { Arts \& } \\
\text { Humanities }\end{array}$ & 1064 & 3.02 & 0.80 & $* * *$ & 0.38 & $* * *$ & 0.36 \\
\hline Biology & 206 & 2.31 & 0.88 & $* * *$ & -0.38 & $* * *$ & -0.40 \\
\hline Business & 370 & 2.64 & 0.97 & NS & -0.03 & NS & -0.06 \\
\hline Education & 290 & 2.93 & 0.82 & $* *$ & 0.28 & $* *$ & 0.28 \\
\hline Engineering & 161 & 2.36 & 0.92 & $* *$ & -0.33 & $* *$ & -0.33 \\
\hline $\begin{array}{l}\text { Physical } \\
\text { Sciences }\end{array}$ & 448 & 2.04 & 0.89 & $* * *$ & -0.67 & $* * *$ & -0.70 \\
\hline Social Science & 520 & 2.57 & 0.92 & NS & -0.11 & NS & -0.12 \\
\hline Professional & 300 & 2.67 & 0.88 & & 0.00 & & \\
\hline Total & 3359 & 2.57 & & & & & \\
\hline
\end{tabular}

For the emphasis on Outcome (2) Written and Oral Communication, Table 23 shows the means of the eight disciplines spread out ranging from 3.02 to 2.04. Ranking from high to low based on their means; the eight academic disciplines are Arts \& Humanity 3.02, Education 2.93, Professionals 2.67, Business 2.64, Social Science 2.57, Engineering 2.36, Biology 2.31, and Physical Science 2.04. Compared with Professionals, the mean of Arts and Humanity is .38 SD above without control, .36 SD with control (ES without control $=.38, p<.001$, ES with control $=.36, p<$ .001 ); the mean of Biology is .38 below without control and -.40 with control (ES without control $=-.38, p<.001$, ES with control $=-.40, p<.001$ ); the mean of Education is .28 SD above both without control and with control (ES without control 
$=.28, p<.001$, ES with control $=.28, p<.001$ ); the mean of Engineering is .33 SD below both with and without control (ES without control $=-.33, p<.001$, ES with control $=-.33, p<.001)$; the mean of Physical Science is .67 SD below without control and .70 SD below with control (ES without control $=-.67, p<.001$, ES with control $=-.70, p<.001)$. These are all appreciable effect sizes compared with Professionals. If comparing the highest with the lowest, that is comparing Arts and Humanity with Physical Science, the effect size is more than one SD $(.36+.70=$ 1.06). That indicates more than $84 \%$ of faculty from physical science score lower or emphasize less than the average of Arts and Humanity faculty members.

For the emphasis on Outcome (3) Quantitative Literacy, Table 24 shows the means of the eight disciplines also spread out ranging from 3.67 (close to 4 , very much) to 1.75 (between $1 \& 2$, very little, \& some). Ranking from high to low based on their means; the eight disciplines are Engineering, Physical Science, Business, Biology, Professionals, Social Science, Education, and Arts \& Humanity. Compared with Professionals, all disciplines’ effect size (except Social Sciences) are appreciable ranging from large 1.13 to small -.21. The mean of Engineering is $1.13 \mathrm{SD}$ above Professionals' with and without control (ES without control $=1.13, p<.001$, ES with control $=1.13, p<.001$ ); the mean of Physical Sciences is 1.01 SD above both with and without control (ES without control $=1.01, p<.001$, ES with control $=1.01, p<$ .001); the mean of Arts and Humanity is .45 SD below Professionals with control, .46 without control (ES without control $=-.46, p<.001$, ES with control $=-.45, p<.001$ ); the mean of Business is .31 SD both with and without control (ES without control = $.31, p<.001$, ES with control $=.31, p<.001$ ); the mean of Biology is .24 SD above 
both without and with control (ES without control $=.24, p<.001$, ES with control $=$ $.24, p<.001$ ); the mean of Education is .22 SD below the Professionals, and .21 below with control (ES without control $=-.22, p<.001$, ES with control $=-.21, p<.001$ ); Comparing Engineering with Education, the standardized mean difference is ES = $1.13+0.21=1.35$, and that is to say that more than $90 \%$ faculty in education emphasis less than the average faculty in Engineering. (Education ranks the second lowest in the emphasis on quantities literacy only to Arts and Humanity, does this explains something about the math problems in K-12 education? If we can not make faculty in Arts and Humanity to emphasize more on quantitative literacy, at least we should convince education colleges to do so).

Table 24

Eight Academic Discipline Difference in Emphasis on Quantitative Literacy (Outcome 3)

\begin{tabular}{lccccccc}
\hline $\begin{array}{l}8 \text { Academic } \\
\text { Discipline }\end{array}$ & $\mathrm{N}$ & MEAN & SD & Sig. & $\begin{array}{l}\text { ES w/o } \\
\text { Control }\end{array}$ & Sig. & $\begin{array}{c}\text { ES with } \\
\text { control }\end{array}$ \\
\hline $\begin{array}{l}\text { Arts \& } \\
\text { Humanities }\end{array}$ & 1052 & 1.75 & 1.05 & $* * *$ & -0.46 & $* * *$ & -0.45 \\
Biology & 203 & 2.60 & 1.03 & $* *$ & 0.24 & $* *$ & 0.24 \\
Business & 369 & 2.69 & 1.15 & $* *$ & 0.31 & $* * *$ & 0.31 \\
$\begin{array}{l}\text { Education } \\
\text { Engineering }\end{array}$ & 290 & 2.04 & 1.14 & $* * *$ & -0.22 & $* *$ & -0.21 \\
$\begin{array}{l}\text { Physical } \\
\text { Sciences }\end{array}$ & 447 & 3.67 & 0.63 & $* * *$ & 1.13 & $* * *$ & 1.13 \\
$\begin{array}{l}\text { Social Science } \\
\text { Professional }\end{array}$ & 517 & 2.12 & 1.16 & NS & -0.15 & NS & -0.14 \\
Total & 302 & 2.30 & 1.10 & & 0.00 & & 0.00 \\
\hline
\end{tabular}

${ }^{* *} p<.01, * * * p<.001$

Control Variables: Accreditation region. 
Table 25

Eight Academic Discipline Difference in Emphasis on Information Literacy (Outcome 4)

\begin{tabular}{|c|c|c|c|c|c|c|c|}
\hline $\begin{array}{l}8 \text { Academic } \\
\text { Discipline }\end{array}$ & $\mathrm{N}$ & MEAN & SD & Sig. & $\begin{array}{l}\text { ES w/o } \\
\text { Control }\end{array}$ & Sig. & $\begin{array}{l}\text { ES with } \\
\text { control } \\
\end{array}$ \\
\hline $\begin{array}{l}\text { Arts \& } \\
\text { Humanities }\end{array}$ & 1072 & 2.89 & 0.57 & $* * *$ & -0.50 & $* * *$ & -0.50 \\
\hline Biology & 211 & 2.84 & 0.61 & $* * *$ & -0.58 & $* * *$ & -0.59 \\
\hline Business & 380 & 3.10 & 0.63 & NS & -0.16 & NS & -0.17 \\
\hline Education & 306 & 3.10 & 0.53 & NS & -0.15 & NS & -0.13 \\
\hline Engineering & 164 & 3.30 & 0.51 & NS & 0.18 & NS & 0.17 \\
\hline $\begin{array}{l}\text { Physical } \\
\text { Sciences }\end{array}$ & 457 & 2.77 & 0.65 & $* * *$ & -0.69 & $* * *$ & -0.70 \\
\hline Social Science & 530 & 2.85 & 0.60 & $* * *$ & -0.57 & $* * *$ & -0.56 \\
\hline Professional & 322 & 3.19 & 0.58 & & 0.00 & & 0.00 \\
\hline Total & 3442 & 3.00 & & & & & \\
\hline
\end{tabular}

${ }^{* *} \mathrm{p}<.01, * * * \mathrm{p}<.001$

Control Variables: accreditation region.

For the emphasis on Outcome (4) information literacy, Table 25 shows means of the eight disciplines are around 3 ranging from 2.77 to 3.30. Ranking from high to low based on their means; the eight academic disciplines are Engineering, Professionals, Education, Business, Arts\& Humanity, Social Science, Biology, and physical Science. Compared to the Professional, the mean of Arts and Humanity is half SD below the Professionals both with and without control (ES without control = $.05, p<.001$, ES with control $=-.05, p<.001$ ); the mean of Biology is 0.58 SD below without control and .59 below with control (ES without control $=-.58, p<.001$, ES with control $=-.59, p<.001)$; the Physical Sciences is .69 SD below without control 
and .70 below the Professionals with control (ES without control $=-.69, p<.001$, ES with control $=-.70, p<.001)$; the mean of Social Science is .57 SD below without control and .56 below with control (ES without control $=-.57, p<.001$, ES with control $=-.56, p<.001)$; Other disciplines’ differences from the Professionals are trivial.

For the emphasis on Outcome (5) Team Work, Table 26 shows the average of the eight disciplines is 2.73 and the eight disciplines' means range from 3.27 to 2.27. Ranking from high to low based on their means; the eight disciplines are Education, Professionals, Business, Engineering, Arts \& Humanity, Biology, Social Science, and Physical Science. Compared with the Professional, the effect sizes larger than .30 include Arts \& Humanity, Biology, Physical Sciences and Social Science. The mean of Arts and Humanity is .30 SD below the Professional, the mean of Biology is .34 below, the mean of Physical science is .73 SD below, and the mean of Social Science is .64 SD below the Professionals. Comparing the highest mean with the lowest, and that is comparing Education with Physical Science, the mean of education emphasizing on Team Work is almost one SD above the mean of physical science (ES $=0.73+.24=.97$ ). 
Table 26

Eight Academic Discipline Difference in Emphasis on Team Work (Outcome 5)

\begin{tabular}{lccccccc}
\hline $\begin{array}{l}8 \text { Academic } \\
\text { Discipline }\end{array}$ & $\mathrm{N}$ & MEAN & SD & Sig. & $\begin{array}{c}\text { ES w/o } \\
\text { Control }\end{array}$ & Sig. & $\begin{array}{c}\text { ES with } \\
\text { control }\end{array}$ \\
\hline $\begin{array}{l}\text { Arts \& } \\
\text { Humanities }\end{array}$ & 1067 & 2.72 & 1.04 & $* * *$ & -0.29 & $* * *$ & -0.30 \\
Biology & 208 & 2.65 & 1.03 & $* * *$ & -0.35 & $* * *$ & -0.34 \\
Business & 370 & 2.80 & 1.03 & $* *$ & -0.20 & $* *$ & -0.21 \\
$\begin{array}{l}\text { Education } \\
\text { Engineering }\end{array}$ & 291 & 3.27 & 0.82 & $* *$ & 0.25 & $* *$ & 0.24 \\
$\begin{array}{l}\text { Physical } \\
\text { Sciences }\end{array}$ & 449 & 2.74 & 0.90 & $* *$ & -0.26 & $* *$ & -0.29 \\
$\begin{array}{l}\text { Social Science } \\
\text { Professional }\end{array}$ & 518 & 2.36 & 1.05 & $* * *$ & -0.64 & $* * *$ & -0.64 \\
Total & 303 & 3.01 & 0.98 & & 0.00 & & \\
\hline
\end{tabular}

$* * p<.01, * * * p<.001$

Control Variables: Teaching experience.

For the emphasis on Outcome (6) Civic Knowledge and Engagement, Table 27 shows the average for the eight disciplines is 2.32, comparatively low. Ranking from high to low with their means, these eight disciplines are Professional 2.59, Education 2.54, Arts \& Humanities 2.49, Social Science 2.43, Biology 2.26, Business 2.19, Engineering 2.03, Physical Sciences 2.03. Compared to Professional, the mean of Arts and Humanities is .14 SD below without control and .18 with control (ES without control $=-.14, p>0.01$, ES with control $=-.18, p<.01$ ); the mean of Biology is .47 SD below without control and .51 SD below with control $((\mathrm{ES}$ without control $=-.47$, $p<.001$, ES with control $=-.51, p<.001$ ); the mean of Business is .56 SD below without control and .62 SD below with control (ES without control $=-.56, p<.001$, 
ES with control $=-.62, p<.001)$; the mean of Engineering is .79 SD below without control and .78 SD below with control; (ES without control $=-.79, p<.001$, ES with control $=-.78, p<.001)$; Physical Sciences is .79 SD below without control and .84 SD below with control (ES without control $=-.79, p<.001$, ES with control $=-.84, p$ $<.001)$; the mean of Social Science is .23 SD below and .26 SD below with control (ES without control $=-.23, p<.001$, ES with control $=-.26, p<.001)$. Only Education's effect size is trivial compared with Professional, all other disciplines have appreciable effect sizes.

Table 27

Eight Academic Discipline Difference in Emphasis on Civic Knowledge and Engagement (Outcome 6)

\begin{tabular}{|c|c|c|c|c|c|c|c|}
\hline $\begin{array}{l}8 \text { Academic } \\
\text { Discipline }\end{array}$ & $\mathrm{N}$ & MEAN & SD & Sig. & $\begin{array}{l}\text { ES w/o } \\
\text { Control }\end{array}$ & Sig. & $\begin{array}{c}\text { ES with } \\
\text { control }\end{array}$ \\
\hline $\begin{array}{l}\text { Arts \& } \\
\text { Humanities }\end{array}$ & 1072 & 2.49 & 0.69 & NS & -0.14 & $* *$ & -0.18 \\
\hline Biology & 212 & 2.26 & 0.64 & $* * *$ & -0.47 & $* * *$ & -0.51 \\
\hline Business & 380 & 2.19 & 0.67 & $* * *$ & -0.56 & $* * *$ & -0.62 \\
\hline Education & 306 & 2.54 & 0.68 & NS & -0.07 & NS & -0.09 \\
\hline Engineering & 164 & 2.03 & 0.68 & $* * *$ & -0.79 & $* * *$ & -0.29 \\
\hline $\begin{array}{l}\text { Physical } \\
\text { Sciences }\end{array}$ & 459 & 2.03 & 0.68 & $* * *$ & -0.79 & $* * *$ & -0.84 \\
\hline Social Science & 530 & 2.43 & 0.72 & $* *$ & -0.23 & $* * *$ & -0.26 \\
\hline Professional & 323 & 2.59 & 0.67 & & 0.00 & & 0.00 \\
\hline Total & 3446 & 2.32 & & & & & \\
\hline
\end{tabular}

For the emphasis on Outcome (7) Intercultural Knowledge and Competence, Table 28 shows the average for the eight disciplines is 2.36 , comparatively low. 
Ranking from high to low with their means, these eight disciplines are Arts \& Humanities 2.87, Social Science 2.59, Education 2.52, Professional 2.46, Business 2.28, Biology 2.15, Physical Sciences 2.05, and Engineering 1.94, Compared with Professional, the mean of Arts \& Humanities is .61 SD above without control, and .58 SD above with control (ES without control $=.61, p<.001$, ES with control $=.58, p<$ .001 ); the mean of Biology is .46 SD below without control and .48 SD below with control ES without control $=-.46, p<.001$, ES with control $=-.48, p<.001)$; the mean of Business is . $28 \mathrm{SD}$ below without control and .31 below with control ES without control $=-.28, p<.001$, ES with control $=-.31, p<.001$ ); the mean of Engineering is .78 SD below without control and .77 SD below with control (ES without control $=-.78, p<.001$, ES with control $=-.77, p<.001$ ); the mean of Physical Sciences is .61 SD below without and .62 SD below with control (ES without control $=-.61 p<.001$, ES with control $=-.62, p<.001)$; the mean of Social Sciences is .19 SD above without control and .16 with control (ES without control $=.19, p<$ .01 , ES with control $=.16, p<.01$ ). So, compared with Professionals, the effect sizes for all disciplines are appreciable and only the effect size for Education is trivial. 
Table 28

Eight Academic Discipline Difference in Emphasis on Intercultural Knowledge and Competence (Outcome 7)

\begin{tabular}{|c|c|c|c|c|c|c|c|}
\hline $\begin{array}{l}8 \text { Academic } \\
\text { Discipline }\end{array}$ & $\mathrm{N}$ & MEAN & SD & Sig. & $\begin{array}{l}\text { ES w/o } \\
\text { Control }\end{array}$ & Sig. & $\begin{array}{c}\text { ES with } \\
\text { control }\end{array}$ \\
\hline $\begin{array}{l}\text { Arts \& } \\
\text { Humanities }\end{array}$ & 1072 & 2.87 & 0.60 & $* * *$ & 0.61 & $* * *$ & 0.58 \\
\hline Biology & 212 & 2.15 & 0.51 & $* * *$ & -0.46 & $* * *$ & -0.48 \\
\hline Business & 380 & 2.28 & 0.64 & $* * *$ & -0.28 & $* * *$ & -0.31 \\
\hline Education & 306 & 2.52 & 0.62 & NS & 0.09 & NS & 0.09 \\
\hline Engineering & 164 & 1.94 & 0.55 & $* * *$ & -0.78 & $* * *$ & -0.77 \\
\hline $\begin{array}{l}\text { Physical } \\
\text { Sciences }\end{array}$ & 459 & 2.05 & 0.53 & $* * *$ & -0.61 & $* * *$ & -0.62 \\
\hline Social Science & 530 & 2.59 & 0.62 & $* *$ & 0.19 & $* *$ & 0.16 \\
\hline Professional & 323 & 2.46 & 0.58 & & 0.00 & & 0.00 \\
\hline Total & 3446 & 2.36 & & & & & \\
\hline
\end{tabular}

For the emphasis on Outcome (8) Ethical Reasoning and Action, Table 29 shows the average for the eight disciplines is 2.46, comparatively low. Ranking from high to low with their means, these eight disciplines are Education 3.01, Professional 2.94, Arts \& Humanities 2.78, Social Science 2.51, Business 2.41, Engineering 2.14, Biology 2.02, Physical Sciences 1.90. Compared with Professional, the mean of Arts \& Humanities is .17 SD below without control, and .19 SD above with control (ES without control $=-.17, p<.01$, ES with control $=-.19, p<.01$ ); the mean of Biology is $.97 \mathrm{SD}$ below without control and $.99 \mathrm{SD}$ below with control ES without control = $.97, p<.001$, ES with control $=-.99, p<.001)$; the mean of Business is .56 SD below without control and .57 below with control (ES without control $=-.56, p<.001$, ES 
with control $=-.57, p<.001$ ); the mean of Engineering is .85 SD below without control and .85 SD below with control (ES without control $=-.85, p<.001$, ES with control $=-.85, p<.001$ ); the mean of Physical Sciences is 1.10 SD below without and 1.13 SD below with control (ES without control $=-1.10, p<.001$, ES with control $=-$ $1.13, p<.001$ ); the mean of Social Sciences is .45 SD below without control and .46 with control (ES without control $=-.45, p<.001$, ES with control $=-.46, p<.01$ ). So, compared with Professionals, the effect sizes for all disciplines are quite large and the one trivial is the effect size for Education.

Table 29

Eight Academic Discipline Difference in Emphasis on Ethical Reasoning and Action (Outcome 8)

\begin{tabular}{|c|c|c|c|c|c|c|c|}
\hline $\begin{array}{l}8 \text { Academic } \\
\text { Discipline }\end{array}$ & $\mathrm{N}$ & MEAN & SD & Sig. & $\begin{array}{l}\text { ES w/o } \\
\text { Control }\end{array}$ & Sig. & $\begin{array}{c}\text { ES with } \\
\text { control }\end{array}$ \\
\hline $\begin{array}{l}\text { Arts \& } \\
\text { Humanities }\end{array}$ & 1068 & 2.78 & 0.86 & $* *$ & -0.17 & $* *$ & -0.19 \\
\hline Biology & 208 & 2.02 & 0.84 & $* * *$ & -0.97 & $* * *$ & -0.99 \\
\hline Business & 371 & 2.41 & 0.87 & $* * *$ & -0.56 & $* * *$ & -0.57 \\
\hline Education & 292 & 3.01 & 0.82 & NS & 0.08 & NS & 0.07 \\
\hline Engineering & 163 & 2.14 & 0.82 & $* * *$ & -0.85 & $* * *$ & -0.85 \\
\hline $\begin{array}{l}\text { Physical } \\
\text { Sciences }\end{array}$ & 448 & 1.90 & 0.83 & $* * *$ & -1.10 & $* * *$ & -1.13 \\
\hline Social Science & 519 & 2.51 & 0.95 & $* * *$ & -0.45 & $* * *$ & -0.46 \\
\hline Professional & 304 & 2.94 & 0.88 & & 0.00 & & 0.00 \\
\hline Total & 3373 & 2.46 & & & & & \\
\hline
\end{tabular}

For the emphasis on Outcome (9) Foundations and Skills for Life Long Learning, Table 30 shows the average for the eight disciplines is 3.22, comparatively 
high. Ranking from high to low with their means, these eight disciplines are Arts \& Humanities 3.43, Professional 3.28, Education 3.26, Social Science 3.20, Physical Sciences 3.17, Biology 3.16, Business 3.16, Engineering 3.07. Compared with Professional, the mean of Arts \& Humanities is .22 SD above without (ES without control $=.22, p<.01$ ), and the mean of Engineering is $.30 \mathrm{SD}$ below without control (ES without control $=.22, p<.01$ ). Other disciplines ES are trivial. There is no control variables introduced for Outcome (9), because the ANOVA analysis in Table 7 indicates no other dependent variables contribute to its variances

Table 30

Eight Academic Discipline Difference in Emphasis on Foundations and Skills for Life Long Learning (Outcome 9)

\begin{tabular}{lccccccc}
\hline $\begin{array}{l}\text { 8 Academic } \\
\text { Discipline }\end{array}$ & $\mathrm{N}$ & MEAN & SD & Sig. & $\begin{array}{c}\text { ES w/o } \\
\text { Control }\end{array}$ & Sig. & $\begin{array}{c}\text { ES with } \\
\text { control }\end{array}$ \\
\hline $\begin{array}{l}\text { Arts \& } \\
\text { Humanities }\end{array}$ & 1067 & 3.43 & 0.63 & $* *$ & 0.22 & & \\
Biology & 208 & 3.16 & 0.72 & NS & -0.17 & & \\
Business & 369 & 3.16 & 0.71 & NS & -0.17 & \\
Education & 292 & 3.26 & 0.73 & NS & -0.03 & \\
Engineering & 162 & 3.07 & 0.66 & $* *$ & -0.30 & \\
$\begin{array}{l}\text { Physical } \\
\text { Sciences }\end{array}$ & 449 & 3.17 & 0.74 & NS & -0.15 & \\
Social Science & 520 & 3.20 & 0.72 & NS & -0.11 & \\
Professional & 303 & 3.28 & 0.70 & & 0.00 & \\
Total & 3370 & 3.22 & & & & \\
\hline$* *$ p $<.01, * * * p<.001$ & & & & & &
\end{tabular}

For the emphasis on Outcome (10) Integrative Learning, Table 31 shows the average for the eight disciplines is 3.17, comparatively high. Ranking from high to 
low with their means, these eight disciplines are Education 3.45, Professional 3.42, Engineering 3.20, Business 3.17, Arts \& Humanities 3.14, Social Science 3.12, Biology 3.07, Physical Sciences 2.77. Compared with Professional, the mean of Arts \& Humanities is $.48 \mathrm{SD}$ below without control, and .49 SD below with control (ES without control $=-.48, p<.001$, ES with control $=-.49, p<.001)$; the mean of Biology is .60 SD below without control and .59 SD below with control ES without control $=-.60, p<.001$, ES with control $=-.59, p<.001)$; the mean of Business is .42 SD below without control and .41 below with control ES without control $=-.42, p<$ .001 , ES with control $=-.41, p<.001$ ); the mean of Engineering is $.38 \mathrm{SD}$ below without control and .42 SD below with control (ES without control $=-.38, p<.001$, ES with control $=-.42, p<.001$ ); the mean of Physical Sciences is 1.10 SD below without and 1.11 SD below with control (ES without control $=-.1 .10 p<.001$, ES with control $=-1.11, p<.001$ ); the mean of Social Sciences is .51 SD below without control and .51 with control (ES without control $=-.51, p<.001$, ES with control $=-$ $.51, p<.001)$. So, compared with Professionals, the effect sizes for all disciplines are appreciable and only the effect size for Education is trivial. 
Faculty and Learning Outcomes 89

Table 31

Eight Academic Discipline Difference in Emphasis on Integrative Learning (Outcome 10)

\begin{tabular}{|c|c|c|c|c|c|c|c|}
\hline $\begin{array}{l}8 \text { Academic } \\
\text { Discipline }\end{array}$ & $\mathrm{N}$ & MEAN & SD & Sig. & $\begin{array}{l}\text { ES w/o } \\
\text { Control }\end{array}$ & Sig. & $\begin{array}{l}\text { ES with } \\
\text { control }\end{array}$ \\
\hline $\begin{array}{l}\text { Arts \& } \\
\text { Humanities }\end{array}$ & 1072 & 3.14 & 0.58 & $* * *$ & -0.48 & $* * *$ & -0.49 \\
\hline Biology & 212 & 3.07 & 0.62 & $* * *$ & -0.60 & $* * *$ & -0.59 \\
\hline Business & 380 & 3.17 & 0.59 & $* * *$ & -0.42 & $* * *$ & -0.41 \\
\hline Education & 306 & 3.45 & 0.47 & NS & 0.05 & NS & 0.03 \\
\hline Engineering & 164 & 3.20 & 0.52 & $* * *$ & -0.38 & $* * *$ & -0.42 \\
\hline $\begin{array}{l}\text { Physical } \\
\text { Sciences }\end{array}$ & 459 & 2.77 & 0.60 & $* * *$ & -1.10 & $* * *$ & -1.11 \\
\hline Social Science & 530 & 3.12 & 0.59 & $* * *$ & -0.51 & $* * *$ & -0.51 \\
\hline Professional & 323 & 3.42 & 0.54 & & 0.00 & & 0.00 \\
\hline Total & 3446 & 3.17 & & & & & \\
\hline
\end{tabular}

For the emphasis on Outcome (11) Problem Solving, Table 32 shows the average for the eight disciplines is 2.90 , comparatively high. Ranking from high to low with their means, these eight disciplines are Education 3.20, Professional 3.13, Business 3.13, Engineering 3.09. Social Science 2.95, Physical Sciences 2.64, Biology 2.53, Arts \& Humanities 2.52, Compared with Professional, the mean of Arts \& Humanities is .61 SD below without and with control (ES without or with control = $.61, p<.001)$; the mean of Biology is .60 SD below without control and .61 with control (ES without control $=-.60, p<.01$, ES with control $=-.61, p<.001$ ); the mean of Physical Sciences is .49 SD below without control or with control (ES without or with control $=-.49, p<.001)$. Other disciplines ES are trivial. 
Table 32

Eight Academic Discipline Difference in Emphasis on Problem Solving (Outcome 11)

\begin{tabular}{|c|c|c|c|c|c|c|c|}
\hline $\begin{array}{l}8 \text { Academic } \\
\text { Discipline }\end{array}$ & $\mathrm{N}$ & MEAN & SD & Sig. & $\begin{array}{l}\text { ES w/o } \\
\text { Control }\end{array}$ & Sig. & $\begin{array}{c}\text { ES with } \\
\text { control }\end{array}$ \\
\hline $\begin{array}{l}\text { Arts \& } \\
\text { Humanities }\end{array}$ & 1061 & 2.52 & 1.04 & $* * *$ & -0.61 & $* * *$ & -0.61 \\
\hline Biology & 203 & 2.53 & 0.95 & $* * *$ & -0.60 & $* * *$ & -0.61 \\
\hline Business & 367 & 3.13 & 0.87 & NS & 0.01 & NS & 0.00 \\
\hline Education & 291 & 3.20 & 0.87 & NS & 0.07 & NS & 0.07 \\
\hline Engineering & 160 & 3.09 & 0.91 & NS & -0.04 & NS & -0.04 \\
\hline $\begin{array}{l}\text { Physical } \\
\text { Sciences }\end{array}$ & 447 & 2.64 & 0.97 & $* * *$ & -0.49 & $* * *$ & -0.49 \\
\hline Social Science & 517 & 2.95 & 0.94 & NS & -0.18 & NS & -0.18 \\
\hline Professional & 303 & 3.13 & 0.93 & & 0.00 & & 0.00 \\
\hline Total & 3349 & 2.90 & & & & & \\
\hline
\end{tabular}

\section{Research Question 4}

Are there any significant differences among the Carnegie Classifications of Institution Types on faculty reports of emphasizing 11 ELOs?

The fifth column in Table 7 presents ANOVA results for question 4. As maybe noted, the three kinds of institutions (Doctorial, Master's and Baccalaureate) differed significantly (at least $p<.01$ ) on 5 dependent variables (or Outcomes), which include Outcome (2) Written and Oral communication, (6) Civic Knowledge and Engagement, (7) Intercultural Knowledge and Competence, (8) Ethical Reasoning and Action, and (11) Problem Solving. There is no statistical significance between these three groups' emphasizing on dependent variables (or outcomes) of (1), (3), (4), (5), (9), and (10). 
To determine the magnitude of the difference between these three groups' emphasizing on dependent variables (or outcomes of 2, 6, 7, 8, 11), effect sizes (ES) were calculated using regression analyses where the dependent measures were first standardized. Tables 33 through 37 present the results with Mean, SD (SD), number of participants (N), and ES for each group.

For the emphasis on Outcome (2) Written and oral communication, Table 33 shows that the mean of these three institutions is 2.68 with mean of baccalaureate ranks the highest at 2.72, mean of master's second 2.71, and mean of Doctoral last, 2.62. Compared with baccalaureate institutions, the mean of Doctoral institutions is .11 SD below without control and .02 with control (ES without control $=-.11, p>.01$, ES with control $=.02, p>.01)$. The mean of master's is .01 SD below without control and .05 with control (ES without control $=-.01 p>.01$, ES with control $=.08, p>$ .01). All of the effect sizes are trivial.

Table 33

Carnegie Type Difference in Emphasis on Written and Oral Communication (Outcome 2)

\begin{tabular}{|c|c|c|c|c|c|c|c|}
\hline $\begin{array}{l}\text { Carnegie } \\
\text { Classification }\end{array}$ & $\mathrm{N}$ & Mean & SD & Sig. & $\begin{array}{l}\text { ES w/o } \\
\text { Control }\end{array}$ & Sig. & $\begin{array}{c}\text { ES } \\
\text { with } \\
\text { Control }\end{array}$ \\
\hline Doctoral & 1681 & 2.62 & 0.94 & NS & -0.11 & NS & 0.02 \\
\hline Master's & 1715 & 2.71 & 0.91 & NS & -0.01 & NS & 0.05 \\
\hline Baccalaureate & 455 & 2.72 & 0.93 & & 0.00 & & \\
\hline Total & 3851 & 2.68 & 0.95 & & & & \\
\hline
\end{tabular}

For the emphasis on Outcome (6) Civic Knowledge and Engagement, Table 34 shows the average of the three institutions is 2.39 , with mean of baccalaureate ranks 
the highest at 2.46, mean of master's second 2.41, and mean of Doctoral last, 2.31. Compared with baccalaureate institutions, the mean of Doctoral institutions is .21 SD below without control, and .11 below with control (ES without control $=-.21, p<$ .001 , ES with control $=-.11, p>.01$ ). The mean of master's is .08 SD below without control, .04 SD above with control (ES without control $=-.08, p>.01$, ES with control $=.04, p>.01)$.

Table 34

Carnegie Type Difference in Emphasis on Civic Knowledge and Engagement (Outcome 6)

\begin{tabular}{|c|c|c|c|c|c|c|c|}
\hline $\begin{array}{l}\text { Carnegie } \\
\text { Classification }\end{array}$ & $\mathrm{N}$ & Mean & SD & Sig. & $\begin{array}{l}\text { ES w/o } \\
\text { Control }\end{array}$ & Sig. & $\begin{array}{c}\text { ES } \\
\text { with } \\
\text { Control }\end{array}$ \\
\hline Doctoral & 1754 & 2.31 & 0.72 & $* * *$ & -0.21 & NS & -0.11 \\
\hline Master's & 1763 & 2.41 & 0.71 & NS & -0.08 & NS & 0.04 \\
\hline Baccalaureate & 465 & 2.46 & 0.71 & & 0.00 & & 0.00 \\
\hline Total & 3982 & 2.39 & 0.67 & & & & \\
\hline
\end{tabular}

For the emphasis on Outcome (7) Intercultural Knowledge and Competence, Table 35 shows the average of the three institutions is 2.51 with mean of baccalaureate ranks the highest at 2.58, mean of master's second 2.48, and mean of Doctoral last, 2.45. Compared with baccalaureate institutions, the mean of Doctoral institutions is .19 SD below without control, and equal with control (ES without control $=-.19, p<$ .001 , ES with control $=-.00, p>.01)$. The mean of master's is .14 SD below without control, .01 SD below with control (ES without control $=-.14, p<.01$, ES with control $=-.01, p>.01)$. All of the effect sizes are trivial. 
Table 35

Carnegie Type Difference in Emphasis on Intercultural Knowledge and Competence (Outcome 7)

\begin{tabular}{|c|c|c|c|c|c|c|c|}
\hline $\begin{array}{l}\text { Carnegie } \\
\text { Classification }\end{array}$ & $\mathrm{N}$ & Mean & SD & Sig. & $\begin{array}{l}\text { ES w/o } \\
\text { Control }\end{array}$ & Sig. & $\begin{array}{c}\text { ES } \\
\text { with } \\
\text { Control }\end{array}$ \\
\hline Doctoral & 1755 & 2.45 & 0.68 & $* * *$ & -0.19 & NS & .00 \\
\hline Master's & 1763 & 2.48 & 0.66 & $* *$ & -0.14 & NS & -.01 \\
\hline Baccalaureate & 465 & 2.58 & 0.67 & & & & \\
\hline Total & 3983 & 2.51 & 0.68 & & & & \\
\hline
\end{tabular}

For the emphasis on Outcome (8) Ethical Reasoning and Action, Table 36 shows the average of the three institutions is 2.55, with mean of Master's ranking the highest at 2.61, mean of baccalaureate second 2.53, and mean of Doctoral last, 2.51. Compared with baccalaureate institutions, the mean of Doctoral institutions is .03 SD below without control, and .04 above with control (ES without control $=-.03, p>.01$, ES with control $=.08, p>.01$ ). The mean of master's is .08 SD above without control, $.10 \mathrm{SD}$ above with control (ES without control $=.08, p>.01$, ES with control $=.10, p$ $>$.01). Effect sizes are all trivial.

Table 36

Carnegie Type Difference in Emphasis on Ethical Reasoning and Action (Outcome 8)

\begin{tabular}{lccccccc}
\hline $\begin{array}{l}\text { Carnegie } \\
\text { Classification }\end{array}$ & $\mathrm{N}$ & Mean & SD & Sig. & $\begin{array}{c}\text { ES w/o } \\
\text { Control }\end{array}$ & Sig. & $\begin{array}{c}\text { ES } \\
\text { with } \\
\text { Control }\end{array}$ \\
\hline Doctoral & 1687 & 2.51 & 0.92 & NS & -0.03 & NS & 0.04 \\
Master's & 1724 & 2.61 & 0.95 & NS & 0.08 & NS & 0.10 \\
Baccalaureate & 458 & 2.53 & 0.96 & & & & \\
Total & 3869 & 2.55 & 0.97 & & & & \\
\hline
\end{tabular}

${ }^{* *} \mathrm{p}<.01, * * * \mathrm{p}<.001$

Control Variables: Eight academic discipline, accreditation region, teaching experience, institution type of control 
For the emphasis on Outcome (11) Problem Solving, Table 37 shows that the average for the three institutions is 2.80 with mean of master's ranking the highest 2.86, Doctoral the second, 2.85, and baccalaureate the third, 2.68. Compared with the baccalaureate institutions, the mean of Doctoral is .18 SD above the mean of baccalaureate without control, and .08 above with control (ES without control $=.18, p$ $<.001$, ES with control $=.08, p>.01)$. The mean of master's institution is $.18 \mathrm{SD}$ above the mean of baccalaureate without control and .10 with control (ES without control $=.18, p<.001$, ES with control $=.10, p>.01)$. After introducing control variables, the effect sizes become trivial.

Table 37

Carnegie Type Difference in Emphasis on Problem Solving (Outcome 11)

\begin{tabular}{|c|c|c|c|c|c|c|c|}
\hline $\begin{array}{l}\text { Carnegie } \\
\text { Classification }\end{array}$ & $\mathrm{N}$ & Mean & SD & Sig. & $\begin{array}{l}\text { ES w/o } \\
\text { Control }\end{array}$ & Sig. & $\begin{array}{c}\text { ES } \\
\text { with } \\
\text { Control }\end{array}$ \\
\hline Doctoral & 1672 & 2.85 & 0.99 & $* * *$ & 0.18 & NS & 0.08 \\
\hline Master's & 1713 & 2.86 & 0.99 & $* * *$ & 0.18 & $* *$ & 0.10 \\
\hline Baccalaureate & 455 & 2.68 & 1.01 & & 0.00 & & \\
\hline Total & 3840 & 2.80 & 0.97 & & & & \\
\hline
\end{tabular}

Out of 11 recommended ELOs, three Carnegie types of institutions differed significantly on five of them; however, the effect sizes calculations indicate the magnitudes of the differences are between modest to trivial. Baccalaureate institutions ranks slightly higher on three of the Outcomes (2, 6, \& 7), and Master’s ranks slightly higher on two of the Outcomes (8\&11). 


\section{Research Question 5}

Are there significant differences between institution types of control (Public or Private) on faculty report of emphasizing 11 ELOs?

The fifth column in Table 7 presents ANOVA results for question 5. As maybe noted, the two type of institutions (Public and Private) differed significantly (at least $p<.01$ ) on 5 dependent variables (or Outcomes), which include Outcome (1) Inquiry, analysis, critical and creative thinking, (2) Written and oral communication, (6) Civic knowledge and engagement, (7) Intercultural knowledge and competence, (8) Ethical reasoning and action. They are not significantly different on the other 6 dependent variables or Outcomes, which are (3) Quantitative literacy, (4) Information literacy, (5) Team work, (9) Foundation and skills for life long learning, (10) Integrative Learning, (11) Problem solving.

To determine the magnitude of the difference between public and private institutions' emphasizing on dependent variables (or Outcomes of 1, 2, 6, 7, 8), effect sizes (ES) were calculated using regression analyses where the dependent measures were first standardized. Table 38 through 42 present the results with Mean, SD (SD), number of participants $(\mathrm{N})$, and ES for each institution.

For the emphasis on Outcome (1) Inquiry, Analysis, Critical and Creative thinking, Table 38 shows the mean of public is 3.54 , and mean for private is 3.62 , both are quite high. Compared to the private, the mean of public is $.08 \mathrm{SD}$ below mean of private without control, and .13 below with control (ES without control $=-.08, p>.01$, ES with control $=-.13, p<.01)$. 
Faculty and Learning Outcomes 96

Table 38

Institution Type of Control Difference in Inquiry and Analysis, Critical, and Creative Thinking (Outcome 1)

\begin{tabular}{lccccccc}
\hline $\begin{array}{l}\text { Institution } \\
\text { Type/Control }\end{array}$ & $\mathrm{N}$ & MEAN & SD & Sig. & $\begin{array}{c}\text { ES } \\
\text { with/o }\end{array}$ & Sig. & $\begin{array}{r}\text { ES with } \\
\text { Control }\end{array}$ \\
\hline Public & 2668 & 3.54 & 0.66 & NS & -0.08 & $* *$ & -0.13 \\
Private & 1273 & 3.62 & 0.59 & & 0.00 & & 0.00 \\
Total & 3941 & 3.58 & 0.63 & & & & \\
\hline
\end{tabular}

${ }^{* *} \mathrm{p}<.01, * * * \mathrm{p}<.001$

Control Variables: academic disciplines.

For the emphasis on Outcome (2) Written and Oral Communication, Table 39 shows the mean of public is 2.61, and mean for private is 2.79. Compared with private, the mean of public is 19 SD below private without control, but if have other influence partial out, which including the influence of discipline difference, accreditation region, and Carnegie Classification, the mean of public is only .07 SD below the mean of private, a trivial effect size (ES without control $=.19, p<.001$, ES with control $=-.07, p>.01)$

Table 39

Institution Type of Control Difference in Emphasis Written and Oral Communication (Outcome 2)

\begin{tabular}{|c|c|c|c|c|c|c|c|}
\hline $\begin{array}{l}\text { Institution } \\
\text { Status }\end{array}$ & $\mathrm{N}$ & MEAN & SD & Sig. & $\begin{array}{c}\text { ES } \\
\text { with/o }\end{array}$ & Sig. & $\begin{array}{l}\text { ES with } \\
\text { Control }\end{array}$ \\
\hline Public & 2670 & 2.61 & 0.93 & $* * *$ & -0.19 & $* * *$ & -0.07 \\
\hline Private & 1277 & 2.79 & 0.91 & & & & \\
\hline Total & 3947 & & & & & & \\
\hline
\end{tabular}

For the emphasis on Outcome (6) Civic Knowledge and Engagement, Table 40 shows the mean of public is 2.32, and mean for private is 2.46 (2, some), compared 
with private, the mean of public is 19 SD below private without control, but if have other influence partial out, which including the influence of discipline difference, accreditation region, and Carnegie Classification, the mean of public is only .08 SD below the mean of private, which is not significant in ES (ES without control $=-.19, p$

$<.001$, ES with control $=-.08, p>.01)$

Table 40

Institution Type of Control Difference in Emphasis on Civic Knowledge and Engagement (Outcome 6)

\begin{tabular}{|c|c|c|c|c|c|c|c|}
\hline $\begin{array}{l}\text { Institution } \\
\text { Status }\end{array}$ & $\mathrm{N}$ & MEAN & SD & Sig. & $\begin{array}{c}\text { ES } \\
\text { with/o }\end{array}$ & Sig. & $\begin{array}{l}\text { ES with } \\
\text { Control }\end{array}$ \\
\hline Public & 2767 & 2.32 & 0.72 & $* * *$ & -0.19 & NS & -0.08 \\
\hline Private & 1314 & 2.46 & 0.70 & & & & \\
\hline Total & 4081 & 2.39 & 0.71 & & & & \\
\hline
\end{tabular}

For the emphasis on Outcome (7) Intercultural Knowledge and Competence, Table 41 shows that the mean of public is 2.43 , and mean of private is 2.58 ( 2 is some, and 3, quite a bit). Compared with private, the mean of public is $.22 \mathrm{SD}$ below without control and .15 SD below with control (ES without control $=-.22, p<.001$, ES with control $=-.15, p<.001)$. 
Faculty and Learning Outcomes 98

Table 41

Institution Type of Control Difference in Emphasis on Intercultural Knowledge and Competence (Outcome 7)

\begin{tabular}{lccccccc}
$\begin{array}{l}\text { Institution } \\
\text { Status }\end{array}$ & $\mathrm{N}$ & MEAN & SD & Sig. & $\begin{array}{c}\text { ES } \\
\text { with/o }\end{array}$ & Sig. & $\begin{array}{c}\text { ES with } \\
\text { Control }\end{array}$ \\
\hline Public & 2768 & 2.43 & 0.67 & $* * *$ & -0.22 & $* * *$ & -0.15 \\
Private & 1314 & 2.58 & 0.66 & & & & \\
Total & 4082 & 2.51 & 0.67 & & & & \\
\hline
\end{tabular}

**p $<.01, * * * \mathrm{p}<.001$

Control Variables: Eight academic discipline, accreditation region, institution type of control.

For the emphasis on Outcome (8) Ethical Reasoning and Action, Table 42 show that the mean of public is 2.51 and mean for private is 2.66. Compared with private, the mean of public is $.15 \mathrm{SD}$ below without control, and .13 below with control (ES without control $=-.12, p<.001$, ES with control $=-.15, p<.001$ )

Table 42

Institution Type of Control Difference in emphasis on Ethical Reasoning and Action (Outcome 8)

\begin{tabular}{lccccccc}
\hline $\begin{array}{l}\text { Institution } \\
\text { Status }\end{array}$ & $\mathrm{N}$ & MEAN & SD & Sig. & ES w/o & Sig. & $\begin{array}{c}\text { ES with } \\
\text { control }\end{array}$ \\
\hline Public & 2680 & 2.51 & 0.94 & $* * *$ & -0.12 & $* * *$ & -0.13 \\
Private & 1286 & 2.66 & 0.95 & & & & \\
Total & 3966 & 2.58 & 0.94 & & & \\
\hline $\begin{array}{l}* * p<.01, * * * p<.001 \\
\text { Control Variables: Eight academic discipline, accreditation region, teaching experience, institution type of control }\end{array}$
\end{tabular}

It is interesting to notice that out of the 11 recommended ELOs, private and public institutions differed significantly on five of them (Table 7, column sixth), however, the effect sizes calculation indicate the magnitude of the differences are 
between small to modest ranging from 0.07 to 0.15 with control. The mean of Private is only slightly higher than the mean of Public on every one of the five ELOs. Research Question 6

Are there any significant differences among categories of Teaching Experience on faculty reports of emphasizing 11 ELOs?

Faculty were organized into 4 groups based on their Teaching Experience, group I has 1-4 years of Teaching Experience, group II has 5-9 years of Teaching Experience, group III has 10-14 years, and group IV has 15 years or more.

The seventh column in Table 7 presents ANOVA results for question 6. As maybe noted, the four groups of faculty differed significantly (at least $p<.01$ ) only on 3 dependent variables (or Outcomes), which include (5) Team work (8) Ethical Reasoning and Action, and (10) Integrative Learning.

To determine the magnitude of the difference between these four groups of faculty's emphasizing on dependent variables (or outcomes of 5, 8, \&10), effect sizes (ES) were calculated using regression analyses where the dependent measures were first standardized. Tables 43 through 45 present the results with Mean, SD (SD), number of participants $(\mathrm{N})$, and ES for each institution.

For the emphasis on Outcome (5) Team Work, Table 43 shows that the average of the four faculty group is 2.74 (close to 3 , quite a bit), with mean of 5-9 years ranks the highest at 2.85, mean of 1-4 years is 2.76, mean of 10-14 years at 2.75, and 15 years and more at 2.60 second 2.48.Compared with the 15 years or more group, the mean of 5-9 years group is .25 SD above without control, and .19 SD above with 
control (ES without control $=.25, p<.001$, ES with control $=.19, p<.001$ ). The size of effect is small. The group of 10-14 year is not significantly different from the 15 or more group when the influence of academic disciplines was partial out.

Table 43

Teaching Experience Difference in Emphasis on Team Work (Outcome 5)

\begin{tabular}{|c|c|c|c|c|c|c|c|}
\hline $\begin{array}{l}\text { Teaching } \\
\text { Experience }\end{array}$ & $\mathrm{N}$ & MEAN & SD & Sig. & $\begin{array}{c}\text { ES } \\
\text { with/o }\end{array}$ & Sig. & $\begin{array}{l}\text { ES with } \\
\text { Control }\end{array}$ \\
\hline 1-4 year & 686 & 2.76 & 1.01 & $* * *$ & 0.16 & NS & 0.05 \\
\hline 5-9 year & 684 & 2.85 & 1.01 & $* * *$ & 0.25 & $* * *$ & 0.19 \\
\hline 10-14 year & 571 & 2.76 & 1.01 & $* * *$ & 0.16 & NS & 0.13 \\
\hline 15 or more & 1829 & 2.60 & 1.04 & & & & \\
\hline Total & 3770 & 2.72 & 1.02 & & & & \\
\hline
\end{tabular}

For the emphasis on Outcome (8) Ethical Reasoning and Action, Table 44 indicate the standardized mean difference between these groups are not significant when variables such as academic disciplines, Accreditation Regions, Carnegie classification, and Institution Types of Control were partial out in the regression. 
Table 44

Teaching Experience Difference in Emphasis on Ethical Reasoning and Action (Outcome 8)

\begin{tabular}{|c|c|c|c|c|c|c|c|}
\hline $\begin{array}{l}\text { Teaching } \\
\text { Experience }\end{array}$ & $\mathrm{N}$ & MEAN & SD & Sig. & $\begin{array}{c}\text { ES } \\
\text { with/o }\end{array}$ & Sig. & $\begin{array}{c}\text { ES } \\
\text { with/o }\end{array}$ \\
\hline 1-4 year & 686 & 2.63 & 0.94 & $* *$ & 0.13 & NS & 0.09 \\
\hline 5-9 year & 737 & 2.63 & 0.95 & $* *$ & 0.14 & NS & 0.07 \\
\hline 10-14 year & 575 & 2.54 & 0.95 & NS & 0.04 & NS & -0.03 \\
\hline 15 or more & 1832 & 2.50 & 0.93 & & & & \\
\hline Total & 3830 & 2.58 & 0.94 & & & & \\
\hline
\end{tabular}

For the emphasis on Outcome (10) Integrative Learning, Table 45 shows that the average of the four groups is 3.18. Still the mean of 5-9 years group ranks the highest, 3.22, and the mean of 15 years or more ranks the lowest, 3.11, but the standard mean difference between these two groups is only .20 without control and .14 with control (ES without control $=.20, p<.001$, ES with control $=.14, p<.01)$. The mean of group 10-14 years is .14 SD above the mean of 15 years or more without control and .12 SD with control. All these sizes of the effect are modest. Especially after introducing control, ES is less than .14. 
Table 45

Teaching Experience Difference in Emphasis on Integrative Learning (Outcome 10)

$\begin{array}{lccccccc}\begin{array}{l}\text { Teaching } \\ \text { Experience }\end{array} & \mathrm{N} & \text { MEAN } & \text { SD } & \text { Sig. } & \begin{array}{c}\text { ES } \\ \text { with/o }\end{array} & \text { Sig. } & \begin{array}{c}\text { ES } \\ \text { with/o }\end{array} \\ \text { 1-4 year } & 697 & 3.17 & 0.56 & \text { NS } & 0.10 & \text { NS } & 0.05 \\ \text { 5-9 year } & 749 & 3.22 & 0.58 & * * * & 0.20 & * * * & 0.14 \\ 10-14 \text { year } & 588 & 3.20 & 0.57 & * * & 0.14 & * * & 0.12 \\ 15 \text { or more } & 1878 & 3.11 & 0.61 & & & & \\ \text { Total } & 3912 & 3.18 & 0.58 & & & & \end{array}$

$* * p<.01, * * * p<.001$

Control Variables: Eight academic discipline, Carnegie classification, institution type of control

It is interesting to notice, out of 11 ELOs, faculty with different years of teaching experience only significantly different on three of them (Table 7, Column 7). Effect size calculation found that out of these three significant ELOs, the group with 5-9 year Teaching Experience ranks higher on two of them (Outcome 5 \& 10) than the other groups, and with no significant difference from others on the left one outcome, which is Outcome 8. After control, effect size ranges from 0.03 to 0.19.

\section{Research Question 7}

Are there any significant differences among Accreditation Regions on faculty reports of emphasizing 11 ELOs?

There are six Accreditation Regions in this analysis. They are Middle States, New England, North Central, North West, Southern, and Western.

The eighth column in Table 7 presents ANOVA results for question 7. As maybe noted, the six Accreditation Regions differed significantly (at least $p<.01$ ) on 6 dependent variables (or Outcomes), which include (2) Written and oral 
communication, (3) Quantitative literacy, (4) Information literacy, (6) Civic knowledge and engagement, (7) Intercultural knowledge and competence, (8) Ethical reasoning and action. They are not significantly different on the other 5 dependent variables (or outcomes) of (1) Inquiry, analysis, critical and creative thinking, (5) Team work, (9) Foundation and skills for life long learning, (10) Integrative Learning, (11) Problem solving.

To determine the magnitude of the difference between the six accreditation regions' emphasizing on dependent variables (or outcomes of 2, 3, 4, 6, 7, 8), effect sizes (ES) were calculated using regression analyses where the dependent measures were first standardized. Tables 46 through 51 present the results with Mean, SD (SD), number of participants $(\mathrm{N})$, and ES for each accreditation region without and with controls.

For the emphasis on Outcome (2) Written and Oral Communication, Table 46 shows that average for the six regions is 2.70 . With means ranking from high to low, the six Accreditation Regions list as Middle States 2.84, New England 2.81, Western 2.73, Southern 2.66, North Central 2.61, and North West 2.56. Compared with the Western, the mean of Middle States is .12 SD above without control and .25 above with control (ES without control $=.12, p>.01$, ES with control $=.25, p<.001$ ), and other effect sizes are trivial. Comparing the highest mean with the lowest, which is comparing Middle States with North West, the effect size with control is .29 SD with control, a medium effect size. Comparing Middle States with North Central, the second lowest, the effect size with control is .28, a medium effect size too. 
Table 46

Accreditation Region Difference in Emphasis on Written and Oral Communication (Outcome 2)

\begin{tabular}{|c|c|c|c|c|c|c|c|}
\hline $\begin{array}{l}\text { Accreditation } \\
\text { Regions } \\
\end{array}$ & $\mathrm{N}$ & MEAN & SD & Sig. & $\begin{array}{c}\text { ES with/o } \\
\text { Control }\end{array}$ & Sig. & $\begin{array}{l}\text { ES with } \\
\text { Control }\end{array}$ \\
\hline Middle States & 512 & 2.84 & 0.92 & NS & 0.12 & $* * *$ & 0.25 \\
\hline New England & 170 & 2.81 & 0.90 & NS & 0.09 & NS & 0.13 \\
\hline North Central & 1688 & 2.61 & 0.94 & NS & -0.13 & NS & -0.03 \\
\hline North West & 199 & 2.56 & 0.90 & $* *$ & -0.19 & NS & -0.04 \\
\hline Southern & 1107 & 2.66 & 0.92 & NS & -0.08 & NS & 0.00 \\
\hline Western & 271 & 2.73 & 0.86 & & & & \\
\hline Total & 3947 & 2.70 & & & & & \\
\hline
\end{tabular}

For the emphasis on Outcome (3) Quantitative Reasoning, Table 47 shows that the average of the six regions is 2.37 (close to 2, some). With means ranking from high to low, the six regions should be listed as Middle States 2.58, North West 2.40, North central 2.37, Southern 2.35, New England 2.34, and Western 2.17. Compared with the Western, the mean of Middle States is .33 SD above without control, and .20 above with control (ES without control $=.33, p<.001$, ES with control $=.19, p<.01$ ). The size of effect with control is small. Introducing control variables reduce the effect size. There is no appreciable ES between Western (the lowest) and other regions. 
Table 47

Accreditation Region Difference in Emphasis on Quantitative Reasoning (Outcome 3)

\begin{tabular}{|c|c|c|c|c|c|c|c|}
\hline $\begin{array}{l}\text { Accreditation } \\
\text { Regions }\end{array}$ & $\mathrm{N}$ & MEAN & SD & Sig. & $\begin{array}{c}\text { ES with/o } \\
\text { Control }\end{array}$ & Sig. & $\begin{array}{c}\text { ES with } \\
\text { control }\end{array}$ \\
\hline Middle States & 508 & 2.58 & 1.22 & $* * *$ & 0.33 & $* *$ & 0.19 \\
\hline New England & 167 & 2.34 & 1.21 & NS & 0.14 & NS & 0.04 \\
\hline North Central & 1684 & 2.37 & 1.22 & NS & 0.16 & NS & 0.11 \\
\hline North West & 198 & 2.40 & 1.22 & $* *$ & 0.19 & NS & 0.11 \\
\hline Southern & 1098 & 2.35 & 1.20 & NS & 0.14 & NS & 0.10 \\
\hline Western & 269 & 2.17 & 1.20 & & & & \\
\hline Total & 3924 & 2.37 & & & & & \\
\hline
\end{tabular}

For the emphasis on Outcome (4) Information literacy, Table 48 shows that the average of the six regions is 2.91 (close to 3, quite a bit). With means ranking from high to low, these six regions are listed as Middle States 3.10, North West 2.98, Southern 2.98, North Central 2.94, Western 2.91, and New England 2.83. Compared with Western, the mean of Middle States is .32 SD above without control and .31 SD above with control (ES without control $=.32, p<.001$, ES with control $=.31, p<$ .001), a medium effect size. ES for other regions are not significant. Comparing the highest mean with the lowest, which is comparing Middle States with New England, the ES with out control is 0.45 , and with control is .39, a medium effect size. 
Table 48

Accreditation Region Difference in Emphasis on Information Literacy (Outcome 4)

\begin{tabular}{|c|c|c|c|c|c|c|c|}
\hline $\begin{array}{l}\text { Accreditation } \\
\text { Regions } \\
\end{array}$ & $\mathrm{N}$ & MEAN & SD & Sig. & $\begin{array}{c}\text { ES with/o } \\
\text { Control }\end{array}$ & Sig. & $\begin{array}{l}\text { ES with } \\
\text { control }\end{array}$ \\
\hline Middle States & 534 & 3.10 & 0.59 & $* * *$ & 0.32 & $* * *$ & 0.31 \\
\hline New England & 173 & 2.83 & 0.61 & NS & -0.13 & NS & -0.08 \\
\hline North Central & 1738 & 2.94 & 0.61 & NS & 0.05 & NS & 0.06 \\
\hline North West & 207 & 2.98 & 0.56 & NS & 0.12 & NS & 0.05 \\
\hline Southern & 1141 & 2.98 & 0.61 & NS & 0.11 & NS & 0.10 \\
\hline Western & 281 & 2.91 & 0.62 & & & & \\
\hline Total & 4074 & 2.96 & & & & & \\
\hline
\end{tabular}

For the emphasis on Outcome (6) Civic Knowledge and Engagement, Table 49 shows that the average of the six regions is 2.37 . With means ranking from high to low, these six regions are listed as Middle States 2.50, Western 2.43, Southern 2.36, North Central 2.34, New England 2.31, and North West 2.27. Compared with Western, the mean of Middle States is .24 SD above with control (ES with control = $.24, p<.001$ ), and the mean of North West is .23 below without control (ES without control $=-.23, p<.01)$. Comparing the highest mean with the lowest, which is comparing Middle States with North West, the ES is ES is .37 SD with control, a medium effect size. 
Table 49

Accreditation Region Difference in Emphasis on Civic Knowledge and Engagement (Outcome 6)

\begin{tabular}{|c|c|c|c|c|c|c|c|}
\hline $\begin{array}{l}\text { Accreditation } \\
\text { Regions } \\
\end{array}$ & $\mathrm{N}$ & MEAN & $\mathrm{SD}$ & Sig. & $\begin{array}{c}\text { ES with/o } \\
\text { Control }\end{array}$ & Sig. & $\begin{array}{c}\text { ES with } \\
\text { control }\end{array}$ \\
\hline Middle States & 535 & 2.50 & 0.72 & NS & 0.10 & $* *$ & 0.24 \\
\hline New England & 173 & 2.31 & 0.74 & NS & -0.17 & NS & -0.13 \\
\hline North Central & 1742 & 2.34 & 0.70 & NS & -0.13 & NS & -0.05 \\
\hline North West & 207 & 2.27 & 0.72 & $* *$ & -0.23 & NS & -0.11 \\
\hline Southern & 1143 & 2.36 & 0.71 & NS & -0.10 & NS & -0.01 \\
\hline Western & 281 & 2.43 & 0.72 & & & & \\
\hline Total & 4081 & 2.37 & & & & & \\
\hline
\end{tabular}

For the emphasis on Outcome (7) Intercultural Knowledge and Competence, Table 50 shows that the average of the six regions is 2.47 . With means ranking from high to low, these six regions are listed as Western 2.59, Middle States 2.53, Southern 2.52, New England 2.47, North Central 2.44, and North West 2.26. Comparing the highest mean with the lowest, that is to compare Western with North West, the mean of North West, is .50 SD below without control (ES without control $=-.50, p<.001$ ), and .35 SD below with control (ES with control $=-.35, p<.001$ ). Comparing the highest with the second lowest, that is to compare the mean of Western and North Central, the mean of North Central is .22 SD below without control (ES without control, $p<.001$ ), and .15 below with control (ES with control, $p>.01$ ). There are no appreciable difference between Western and other regions. 
Table 50

Accreditation Difference in Emphasis on Intercultural Knowledge and Competence (Outcome 7)

\begin{tabular}{|c|c|c|c|c|c|c|c|}
\hline $\begin{array}{l}\text { Accreditation } \\
\text { Regions }\end{array}$ & $\mathrm{N}$ & MEAN & SD & Sig. & $\begin{array}{c}\text { ES with/o } \\
\text { Control }\end{array}$ & Sig. & $\begin{array}{c}\text { ES with } \\
\text { control }\end{array}$ \\
\hline Middle States & 535 & 2.53 & 0.66 & NS & -0.09 & NS & -0.07 \\
\hline New England & 173 & 2.47 & 0.69 & NS & -0.18 & NS & -0.11 \\
\hline North Central & 1743 & 2.44 & 0.67 & $* * *$ & -0.22 & NS & -0.15 \\
\hline North West & 207 & 2.26 & 0.69 & $* * *$ & -0.50 & $* * *$ & -0.35 \\
\hline Southern & 1143 & 2.52 & 0.66 & NS & -0.11 & NS & -0.06 \\
\hline Western & 281 & 2.59 & 0.67 & & 0.00 & & \\
\hline Total & 4082 & 2.47 & & & & & \\
\hline
\end{tabular}

For the emphasis on Outcome (8) Ethical Reasoning and Action, Table 51 shows that the average of the six regions is 2.56 . With means ranking from high to low, these six regions are listed as Middle States 2.66, Western 2.65, Southern 2.58, New England 2.54, North Central 2.51, and North West 2.43. Compared with Western, the mean of North West is .23 SD below without control (ES without control $=-.50, p<.01)$, and .15 SD below with control (ES with control $=-.15, p>.01)$. Introducing the control variables reduced ES from medium to modest. There are no appreciable differences between Western and Other regions. Comparing the highest mean with the lowest, that is comparing Middle States with North West, the mean of Middle States is .24 SD above the mean of North West without control (ES without control $=.24, p<.001$ ), and .26 SD above the mean of North West with control (ES with control $=.26, p<.001)$. 
Table 51

Accreditation Difference in Emphasis on Ethical Reasoning and Action (Outcome 8)

\begin{tabular}{|c|c|c|c|c|c|c|c|}
\hline $\begin{array}{l}\text { Accreditation } \\
\text { Regions }\end{array}$ & $\mathrm{N}$ & MEAN & SD & Sig. & $\begin{array}{c}\text { ES with/o } \\
\text { Control }\end{array}$ & Sig. & $\begin{array}{c}\text { ES with } \\
\text { control }\end{array}$ \\
\hline Middle States & 519 & 2.66 & 0.96 & NS & 0.01 & NS & 0.09 \\
\hline New England & 169 & 2.54 & 0.97 & NS & -0.11 & $* *$ & -0.19 \\
\hline North Central & 1695 & 2.51 & 0.95 & NS & -0.15 & NS & -0.10 \\
\hline North West & 200 & 2.43 & 0.88 & $* *$ & -0.23 & NS & -0.17 \\
\hline Southern & 1110 & 2.58 & 0.93 & NS & -0.07 & NS & -0.03 \\
\hline Western & 273 & 2.65 & 0.92 & & & & \\
\hline Total & 3966 & 2.56 & & & & & \\
\hline
\end{tabular}

It is interesting to notice that among these six Accreditation Regions, Middle States ranks on the top regarding five Outcomes out of the significant six Outcomes, and ranks in the second place regarding the other one Outcome (Outcome 7). The differences in magnitude between the Middle States and the others (whichever ranks at the bottom) ranges from .19 to .39 SD with control, they are appreciable effect sizes.

To provide a summary analysis of all findings, Table 52 assembles all effect sizes and effect size ranges. From this table, we notice that the largest effect sizes are located in the Eight Discipline group (ES rang from .39 to 1.48), which indicates the differences in magnitudes are quite large between these eight disciplines for each of the 11 ELOs (Column 4). We can also find there are many appreciable effect sizes in the group of Professional \& Applied vs. Others, and the group of Professional vs. Applied \& Others in Column 2, and Column 3. In the last column (Column, 8), we 
also spot some appreciable effect sizes among the six accreditation regions. There are no medium or large effect sizes in the groups of Carnegie Classification, Type of Control, Teaching Experience (Column 4, 5, \& 6). 
Table 52

Effect Sizes and Effect Size Ranges for Seven Independent Variables and 11 Dependent Variables

\begin{tabular}{|c|c|c|c|c|c|c|c|}
\hline & $\begin{array}{c}\text { Prof.\& } \\
\text { Applied } \\
\text { Vs. } \\
\text { Others }\end{array}$ & $\begin{array}{c}\text { Prof. Vs. } \\
\text { Applied } \\
\& \\
\text { Others }\end{array}$ & $\begin{array}{c}\text { Eight } \\
\text { Disciplines }\end{array}$ & $\begin{array}{c}\text { Carnegie } \\
\text { Classification }\end{array}$ & $\begin{array}{l}\text { Type of } \\
\text { Control }\end{array}$ & $\begin{array}{c}\text { Teaching } \\
\text { Experience }\end{array}$ & $\begin{array}{c}\text { Accreditation } \\
\text { Regions }\end{array}$ \\
\hline & ES & ES & ES range & ES range & ES & ES range & ES range \\
\hline Outcome 1 & - & - & $\begin{array}{c}-0.38 \_0.01 \\
(0.39)\end{array}$ & - & -0.13 & - & - \\
\hline Outcome 2 & - & - & $\begin{array}{c}-0.70 \_0.36 \\
(1.06)\end{array}$ & $\begin{array}{c}-0.02 \_0.05 \\
(0.07)\end{array}$ & -0.07 & - & $\begin{array}{l}-0.03 \_0.25 \\
\quad(0.28)\end{array}$ \\
\hline Outcome 3 & -0.23 & - & $\begin{array}{c}-0.45 \_1.03 \\
(1.48)\end{array}$ & - & - & 一 & $\begin{array}{c}0.00 \_0.19 \\
(0.19)\end{array}$ \\
\hline Outcome 4 & -0.50 & -0.43 & $\begin{array}{c}-0.59 \_0.17 \\
(0.76)\end{array}$ & - & - & - & $\begin{array}{c}-0.08 \_0.31 \\
(0.39)\end{array}$ \\
\hline Outcome 5 & -0.42 & -0.36 & $\begin{array}{c}-0.73 \_0.24 \\
(0.97)\end{array}$ & - & - & $\begin{array}{c}0.00 \_0.19 \\
(0.19)\end{array}$ & - \\
\hline Outcome 6 & - & -0.39 & $\begin{array}{c}-0.84 \_0.00 \\
(0.84)\end{array}$ & $\begin{array}{c}-0.11 \_0.04 \\
(0.14)\end{array}$ & -0.08 & - & $\begin{array}{c}-0.13 \_0.24 \\
(0.37)\end{array}$ \\
\hline Outcome 7 & 0.32 & - & $\begin{array}{c}-0.77 \_0.58 \\
(1.35)\end{array}$ & $\begin{array}{c}-0.01 \_0.00 \\
(0.01)\end{array}$ & -0.15 & - & $\begin{array}{c}-0.35 \_-0.06 \\
(0.29)\end{array}$ \\
\hline Outcome 8 & -0.23 & -0.48 & $\begin{array}{c}-1.13 \_0.07 \\
(1.20)\end{array}$ & $\begin{array}{c}0.00 \_0.04 \\
(0.04)\end{array}$ & -0.13 & $\begin{array}{c}-0.03 \_0.09 \\
(0.12)\end{array}$ & $\begin{array}{l}-0.35 \_0.00 \\
(0.35)\end{array}$ \\
\hline Outcome 9 & 0.14 & - & $\begin{array}{c}-0.30 \_0.22 \\
(0.52)\end{array}$ & - & - & - & - \\
\hline Outcome 10 & -0.45 & -0.52 & $\begin{array}{c}-1.11 \_0.03 \\
(1.14)\end{array}$ & - & - & $\begin{array}{c}0.00 \_0.14 \\
(0.14)\end{array}$ & - \\
\hline Outcome 11 & -0.50 & -0.35 & $\begin{array}{c}-0.61 \_0.07 \\
(0.68)\end{array}$ & $\begin{array}{c}0.00-0.10 \\
(0.10)\end{array}$ & - & 一 & - \\
\hline
\end{tabular}




\section{Chapter 5: Conclusions and Implication}

This study found that the 11 Essential Learning Outcomes (ELOs) recommended by AAC\&U (2007) are endorsed by faculty members with different teaching experience across academic disciplines, type of institutions, and accreditation regions. However, the degree of emphasis given by faculty members differed significantly $(p<.01)$ among the seven treatment groups, which are (1) two groups of Professional \& Applied versus Others, (2) two groups of Professional versus Applied \& Others, (3) eight groups of Academic Disciplines, (4) three groups of Carnegie Classifications, (5) two groups of Institution Types of Control, (6) four groups of Teaching Experience, and (7) six groups of Accreditation Regions. Many of the effect sizes (ESs) indicate that the differences in magnitude among them are appreciable. Faculty in Professional and Applied Fields' Support for the ELOs

The two groups of faculty (one is in professional and applied fields, and the other is in all remaining disciplines) differed significantly $(p<.01)$ on endorsing eight of the 11 ELOs (Table 7, Column 2). Faculty members from professional and applied fields emphasized more on six of the eight significant ELOs than faculty members from in the other group did. The differences in magnitude are considerable (Table 52).

One of the issues addressed by the AAC\&U (2007) report is that liberal education is not practiced enough in colleges. "Many see liberal education as the 'nonvocational' or 'less' marketable part of the curriculum... this twentieth-century view, is now obsolete” (p.13). Liberal education, which is represented by ELOs, is "needed in every part of life, including the workplace, and in all fields of study, including the professional and occupational fields” (p.14). Therefore, the report insisted "these 
ELOs should be addressed in different ways across varied fields of study....and not just in the first two years of college” (p. 14). Making such a strong recommendation is also due to the fact that a majority of students head to college for jobs. They choose occupation-oriented majors, instead of the traditional liberal arts, and this has been a trend since the aftermath of World War II (Bok, 2006). Accordingly, this study analyzed the degree of support for ELOs by faculty members in Professional \& Applied fields relative to faculty members in the group of Others, which includes arts \& humanities, biology, physical sciences, and social sciences. The group of Professional \& Applied includes medicine, law, veterinarian, nursing, pharmacy, business, education, engineering, etc. (Detailed discipline information see attachment 2)

We found that the emphasis on ELOs varied between the two groups (Professional \& Applied vs. Others). They differed significantly $(p<.01)$ on eight of the 11 ELOs (Table 7, Column 2).

The effect sizes (ESs) shows that regarding these eight significant ELOs, faculty in the Professional \& Applied group emphasized more than the Others on six of them (ELO 3, 4, 5, 8, 10, \&11) with ES of .23, .50, 42, .23, .45, and .50 (all with control, $p<.001)$, respectively.

Professional \& Applied group put less emphasis on the remaining two ELOs (ELO 7 \& 9) with ES of .32 and .14 (with control, $p<.001$ ). Results are shown in Figure 1. 
Fig.1 Others Emphasis on ELOs Compared with Prof. \& Applied

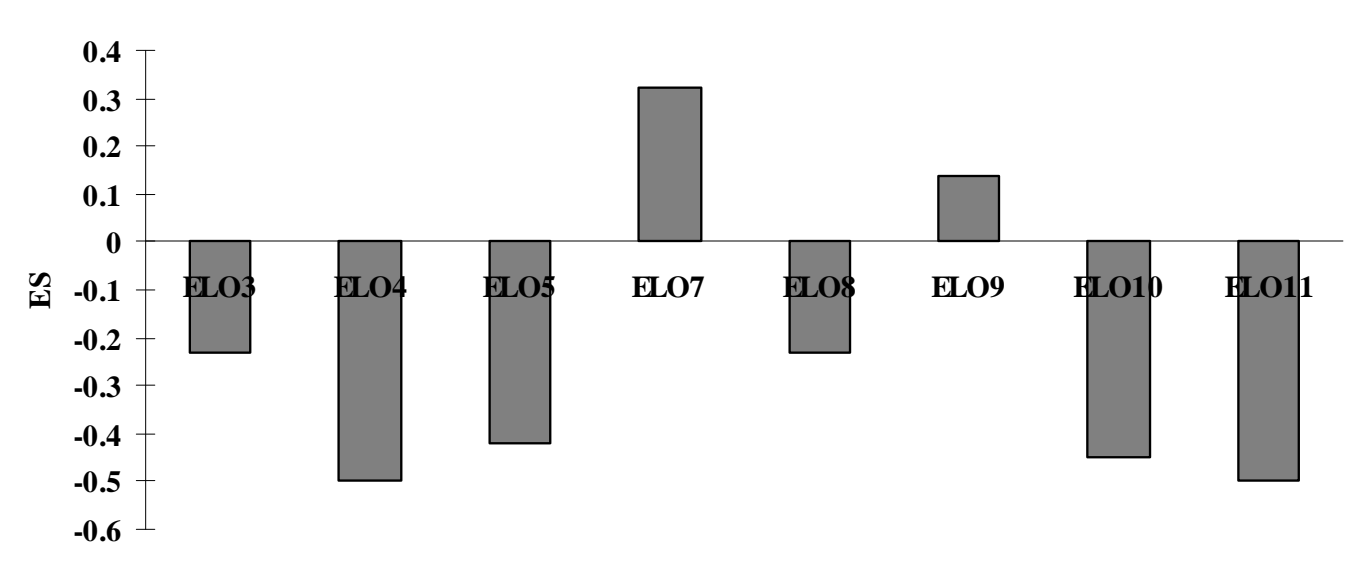

The ESs indicate that the differences in magnitude between the two groups are noticeable. All ESs can be converted into statements in terms of comparison of percentiles (Cohen, 1965). For example, ES .50 (on ELO 4) reveals that the average faculty members in the Professional \& Applied group emphasized Information Literacy more than $69 \%$ of faculty members in the group of Others did. Faculty in Professional Fields' Support for the ELOs

The two groups of faculty (one is in professional, and the other is a combination of applied and the remaining disciplines) differed significantly $(p<.01)$ on six of the 11 ELOs (Table 7, Column 3). Regarding these six significant ELOs, faculty members in professional gave more emphasis on all of them than others did, and the differences in magnitude are appreciable (Table 53).

To find how faculty members in professional fields endorse ELOs, we set them alone as one group (Professional), and compared it with the other group as a combination of the “Applied” and the “Others” (Applied \& Others). The group of Applied \& Others includes faculties in arts \& humanities, biology, business education, engineering, physical sciences, and social Sciences. 
We found that the emphasis given by the above two groups differed significantly $(p<.01)$ on six (ELO 4, 5, 6, 8, 10, \&11) of the 11 ELOs with no statistical significant on the remaining five (ELO 1, 2, 3, 7, 9) (Table 7, column 3). Again, very surprisingly, through the ES calculations, we found that faculty in the Professional emphasized more on all of the six significant ELOs than faculty from Applied \& Others did. The ESs for each of the ELOs of 4, 5, 6, 8, 10, \& 11 are .43, .36, .39, .48, .52, and .35 (all with control, $p<.001$ ), respectively. The differences in magnitude are obvious as seen in Figure 2

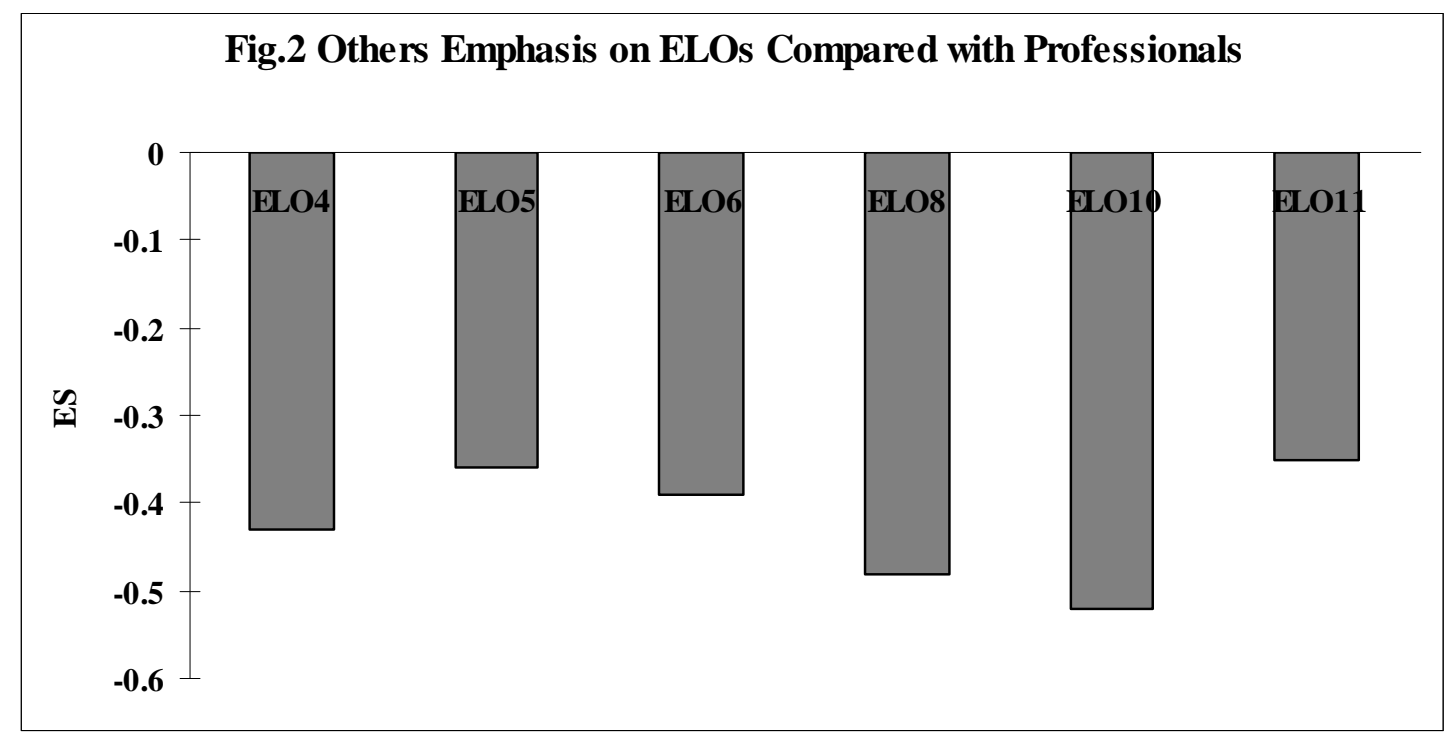

In terms of comparison percentile, for example, the results tell us the average of faculty members in professional emphasized Civic Knowledge and Engagement more than about $66 \%$ of other faculty members did, and they emphasized Ethical Reasoning and Action more than about 69\% of other faculty members did.

These encouraging findings might be explained by the strong advocates of integrating liberal education and vocational oriented programs from professional organizations, as reviewed in the literature. Curry \& Wergin (1993) reported that 
integration has been an apparent theme in the reform proposals in the 1980s and 1990s. Business leaders, governmental agencies, professional fields such as law, medicine, engineering and teaching had realized that college graduates lack the essential skills employers and other constituents expect of students upon completion of an undergraduate degree program (Van Horn, 1995). The professionals agreed that practitioners must understand the technical and theoretical facets of the fields; however, technical knowledge alone is not sufficient to successfully practice in today's professional environments. Integrating skills and knowledge introduced in general education course into the major fields of study allow students to develop professional expertise vital for career success.

Over ten years of reforming, it seems they are making some noticeable differences. At least, faculty members in these fields have generally realized that it is their responsibility not only to teach students specific knowledge in the profession, but also create opportunities for students to develop skills and responsibilities described in ELOs.

Faculty across Disciplines’ Support for ELOs

Faculty members across disciplines differed significantly $(p<.01)$ on endorsing each of the 11 ELOs (Table 7, Column 4, p.64), and most of differences in magnitude are large (Table 53).

One import recommendation made by the AAC\&U (2007) report is that across disciplines, faculty members should cultivate the 11 ELOs in a way appropriate to their fields of studies. Therefore, it is every faculty member's responsibility to cultivate, for example, "Written and Oral Communication” skills, and "Inquiry, 
Analysis, Critical and Creative Thinking,” because “engineering uses quite different inquiry and communication skills than anthropology" (p.14). To find out how faculties across disciplines embrace this recommendation, we categorized faculties into eight groups as (a) Arts \& Humanities (b) Biology. (c) Business (d) Education, (e) Engineering (f) Physical Sciences (g) Social Sciences and (h) Professional, and compared their emphasis on each of the ELOs:

ELO (1) Inquiry and Analysis, Critical and Creative Thinking: The study found that, on average, faculty members emphasized this skill between "quite a bit" and "very much" (mean 3.55, comparatively high). Faculty members in Arts and Humanities emphasized it the most, and faculty members in Biology emphasized it the least. The difference in magnitude between these two groups is .39 (with control, $p<$ .001), which can be interpreted as the average faculty members in Arts and Humanity emphasized ELO (1) more than 66\% of faculty members in Biology did. The ESs between any other two disciplines are less than .21, which means the differences in magnitude between all disciplines are not appreciable, even though the ANOVA test found they are significantly different at high power level $(p<.01)$. Results are illustrated in Figure 3.

ELO (2) Written and Oral Communication: We found that on average, faculty members emphasized this skill between "some” and "quite a bit” (mean 2.57). Arts \& Humanities give it the strongest support (mean, 3.02, and ES is .36, $p<.001$ with control) and the support from other disciplines ranking from high to low is in such order: Education, Professionals, Business, Social Sciences, Engineering, Biology, and Physical Sciences. Compared with the Professional, ES for each of these disciplines 


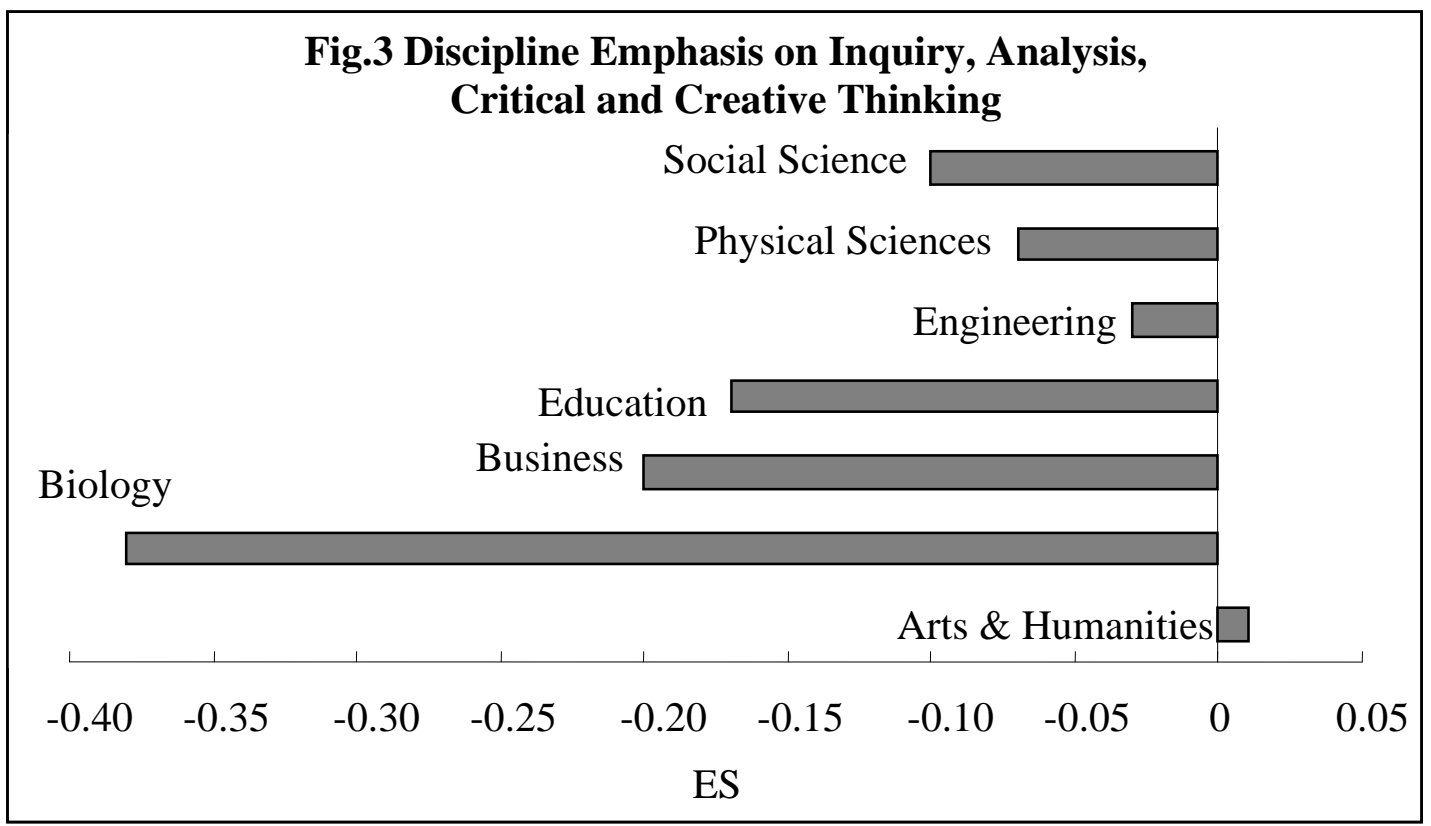

are as .36, .28, -.06, -.12, -.33, -.40, -.70, respectively (all with control, $p<.001$ ).

These ESs indicate the differences in magnitude between the eight groups of faculties are quite large and with these ESs, we can find differences between any two groups regarding the emphasis on ELO (2). For example, compared the Arts \& Humanities with the Physical Sciences, the ES is $(.36+.70=1.06)$, and that indicates the average of faculty members in Arts and Humanities emphasized Written and Oral Communication skills more than $84 \%$ of faculty members from Physical Sciences did. The results for ELO (2) can also be illustrated in Figure 4.

In his 2006 book, Our Underachieving Colleges, former Harvard University President Derek Bok reported that research has found college students’ progress in writing was distributed most unevenly in research universities. "Humanities majors made great progress, Social Sciences majors improved moderately, but students concentrating in Physical Sciences failed to improve or actually regressed” (Bok, 2006, p.89). This report mirrors our research findings: Faculty members in Physical 


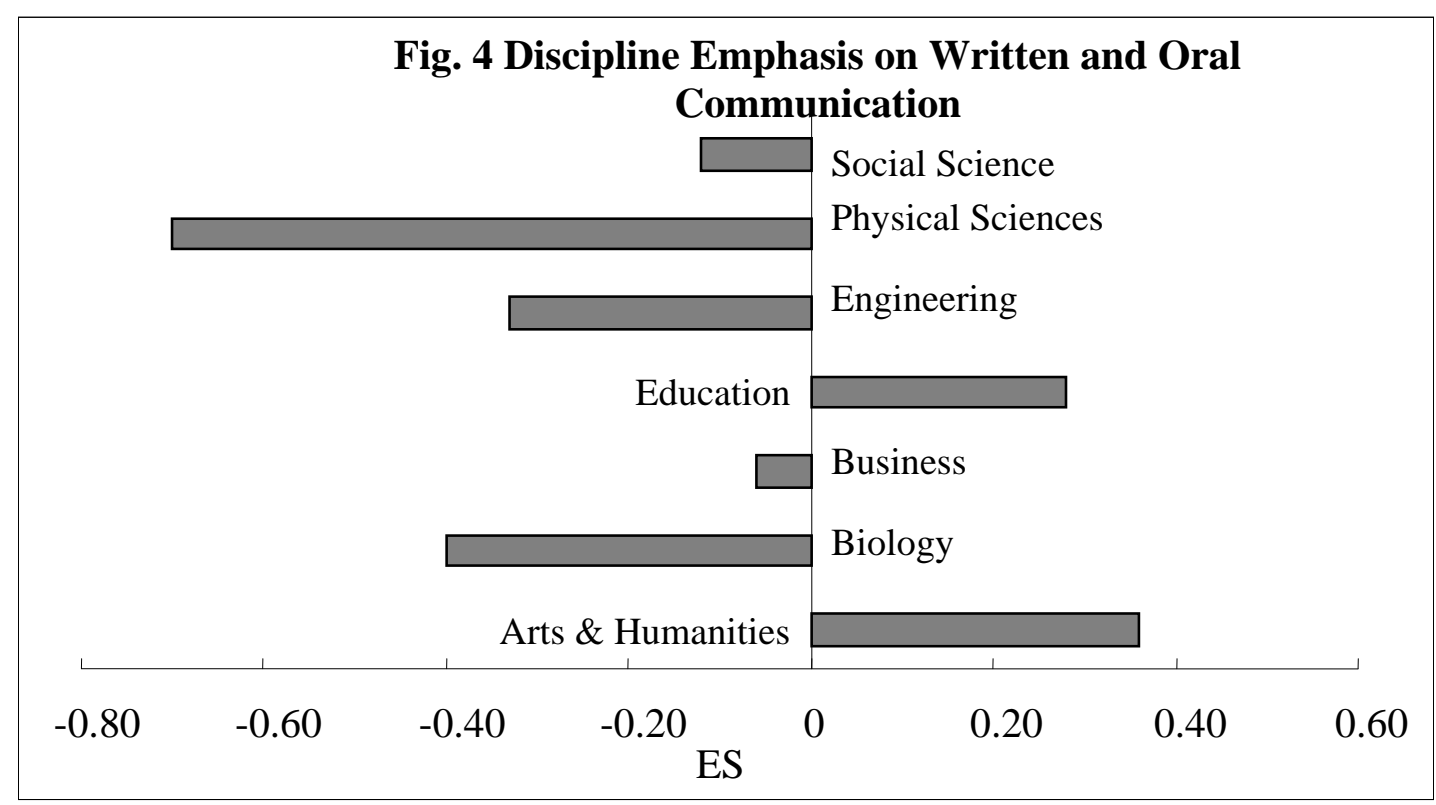

Sciences emphasized Writing and Communication the least. Arts and Humanities emphasized it the most, and the Social Sciences in between. Maybe we could never expect faculty members in Physical Sciences and Arts \& Humanities to put the same degree of emphasis on writing, but students in Physical Sciences need to improve their writing and communication skills. "Writing across the Curriculum” was initiated as early as in the 1970s (Bok, 2006), but it seems the program never became integrated into some academic areas.

ELO (3) Quantitative Literacy: The research found that on average, faculty members emphasized this skill between "some” and “quite a bit” (mean 2.59). Engineering gave the strongest support (mean, 3.67, ES, 1.13, $p<.001$ with control) and support from other disciplines ranking from high to low is in such order: Physical Sciences, Business, Biology, Professionals, Social Sciences, Education, and Arts \& Humanities. Compared with Professional, ES for each of the other disciplines are 1.01, 
$.31, .24,-.14,-.21-.45$ (all with control, $p<.001$ ), respectively. Figure 5 illustrates the results.

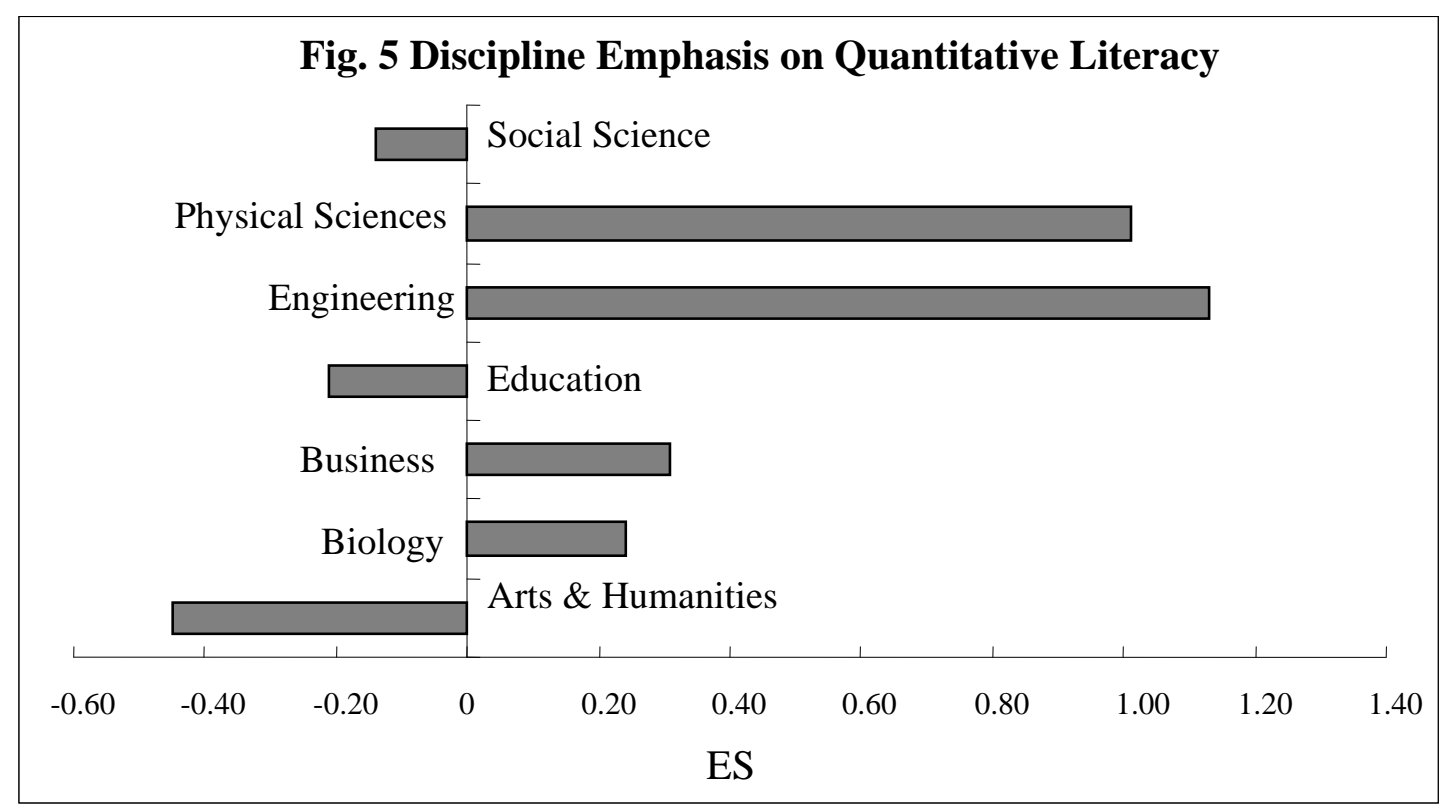

The ESs indicate the differences between the eight groups are quite large.

Using ESs, we can find differences between any two groups regarding emphasis on Quantitative Literacy. For example, Education ranks the second lowest only to Arts and Humanities. Compared it with Engineering, the ES is 1.34 (with control, $p<$ .001), which reveals that more than $90 \%$ faculty from education emphasized Quantitative Literacy less than the average faculty members in Engineering did.

These results shed light on the problems identified by AAC\&U (2007). They warned that America is losing comparative advantage in the so-called STEM disciplines: science, technology, engineering and mathematics. The degree of low emphasis on Quantitative Literacy by Education, which prepares tomorrow's teachers, is alarming. Faculty in Engineering and Physical Sciences, of course highly endorse 
these skills, but to regain competences in STEM disciplines should start with Education Colleges.

ELO (4) Information Literacy: Our research found average faculty members emphasized this skill “quite a bit” (mean 3.00). Faculty members in engineering gave the strongest support (mean, 3.30, and ES is .17, $p<.001$ with control) and support from other disciplines ranking from high to low is in such order: Professionals, Education, Business, Arts \& Humanity, Social Sciences, Biology, and Physical Sciences. Compared with the Professional, the appreciable ESs for each of the disciplines are Arts and Humanity - .50, Biology - .59, Physical Sciences - .70, and Social Sciences - .56; other disciplines ESs are trivial as illustrated in Figure 6.

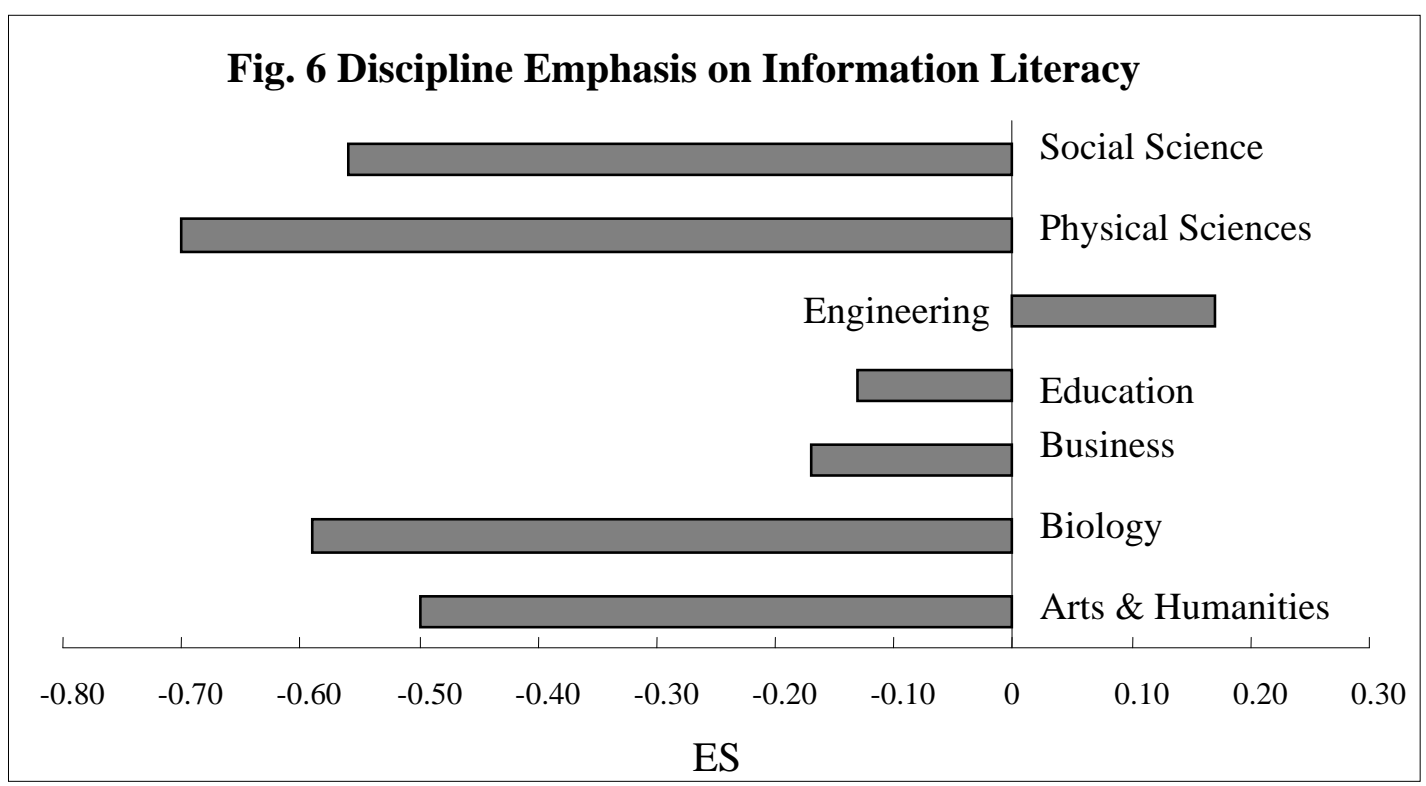

Differences between any two disciplines can be found by using the reported ESs. For example, compared Engineering with Physical Sciences, the ES is .87 (ES = $.17+.70=.87$ with control), and that indicates the average of faculty members in 
Engineering emphasis more on Information Literacy than $79 \%$ of faculty members in Physical Sciences did.

ELO (5) Team Work: we found average faculty members emphasized this skill “quite a bit” (mean 2.73). Faculty members in Education gave the strongest support (mean, 3.27, and ES is .24, $p<.001$ with control) and support from other disciplines ranking from high to low is in such order: Professionals, Business, Engineering, Arts \& Humanities, Biology, Social Sciences, and Physical Sciences. Compared with the Professional, the ESs for each of the seven disciplines are .24, -.21, -.29, -.30, -.34, $.64,-.73$ (with control, $p<.001$ ) respectively. Figure 7 illustrates the results.

With reported ESs we can find differences between any two groups regarding emphasis on Team Work. For example, comparing Education with Physical Sciences,

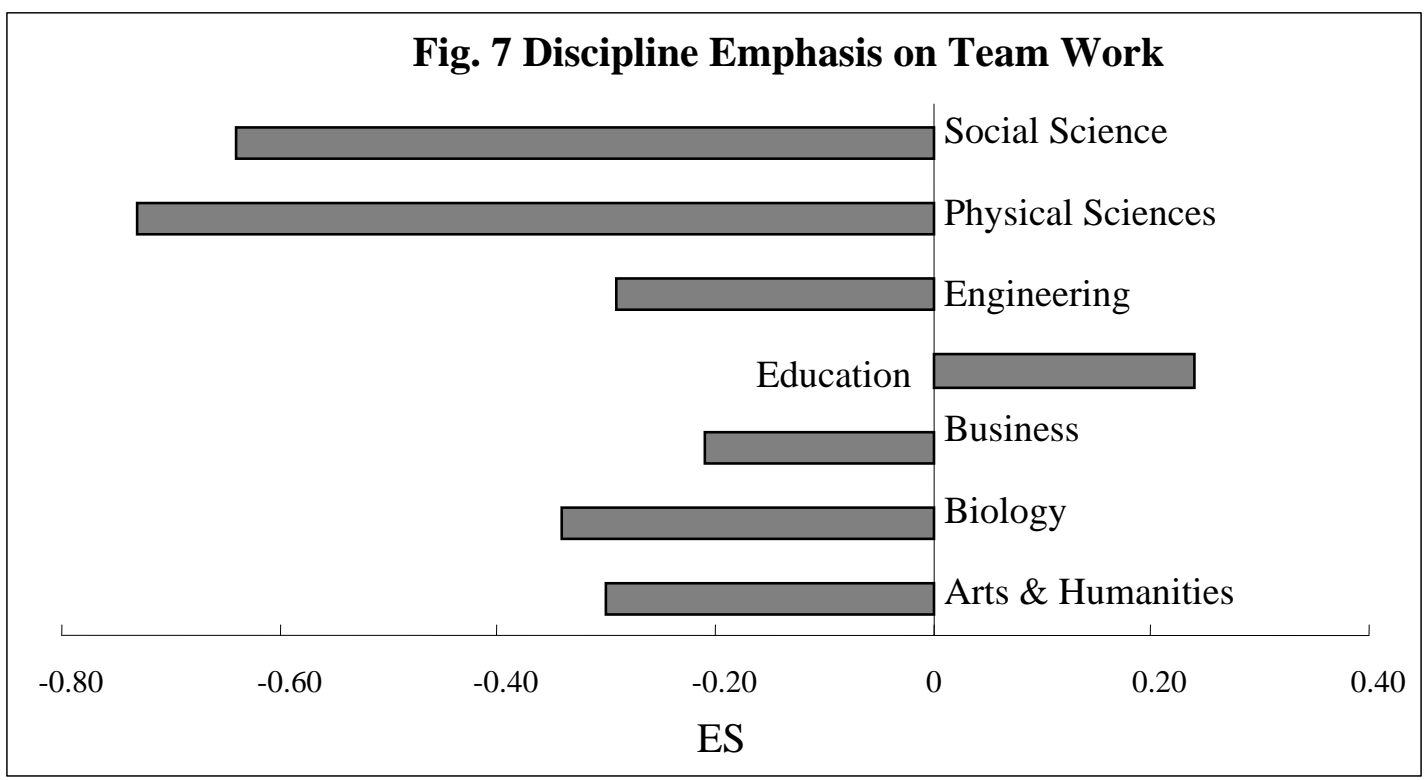

which have the highest and the lowest mean score respectively for this ELO, we found the ES is .97, and that indicates more than $82 \%$ of faculty from Physical Sciences emphasized less on Team Work than faculty members from Education did. 
Bok (2006) suggested learning could be more productive through group work. Especially, he provided examples of how collaborative learning could benefit students in math and physical sciences. However, our study indicates, faculty in the Physical Sciences emphasized Team Work the least. Team Work has not been as widely endorsed by faculty in the physical sciences disciplines as in education and in other disciplines.

ELO (6) Civic Knowledge and Engagement: we found average faculty members emphasized this skill "some” (mean 2.32, comparatively low). Faculty members in Professional give the strongest support (mean, 2.59) and support from other disciplines ranking from high to low is in such order: Education, Arts \& Humanities, Social Sciences, Biology, Business, Engineering, Physical Sciences. Compared with the Professional, the ES for Physical Sciences is - .84, Engineering is .78 , Business is -.62 , and Biology is -.51 (all with control, $p<.001$ ), as seen in Figure 8. These are medium to large ESs and the differences between them are appreciable. For example, ES for Physical Sciences is - .84 and that indicates about 80\% faculty in Physical Sciences emphasized Civic Knowledge and Engagement less than faculty members in Professional did. 


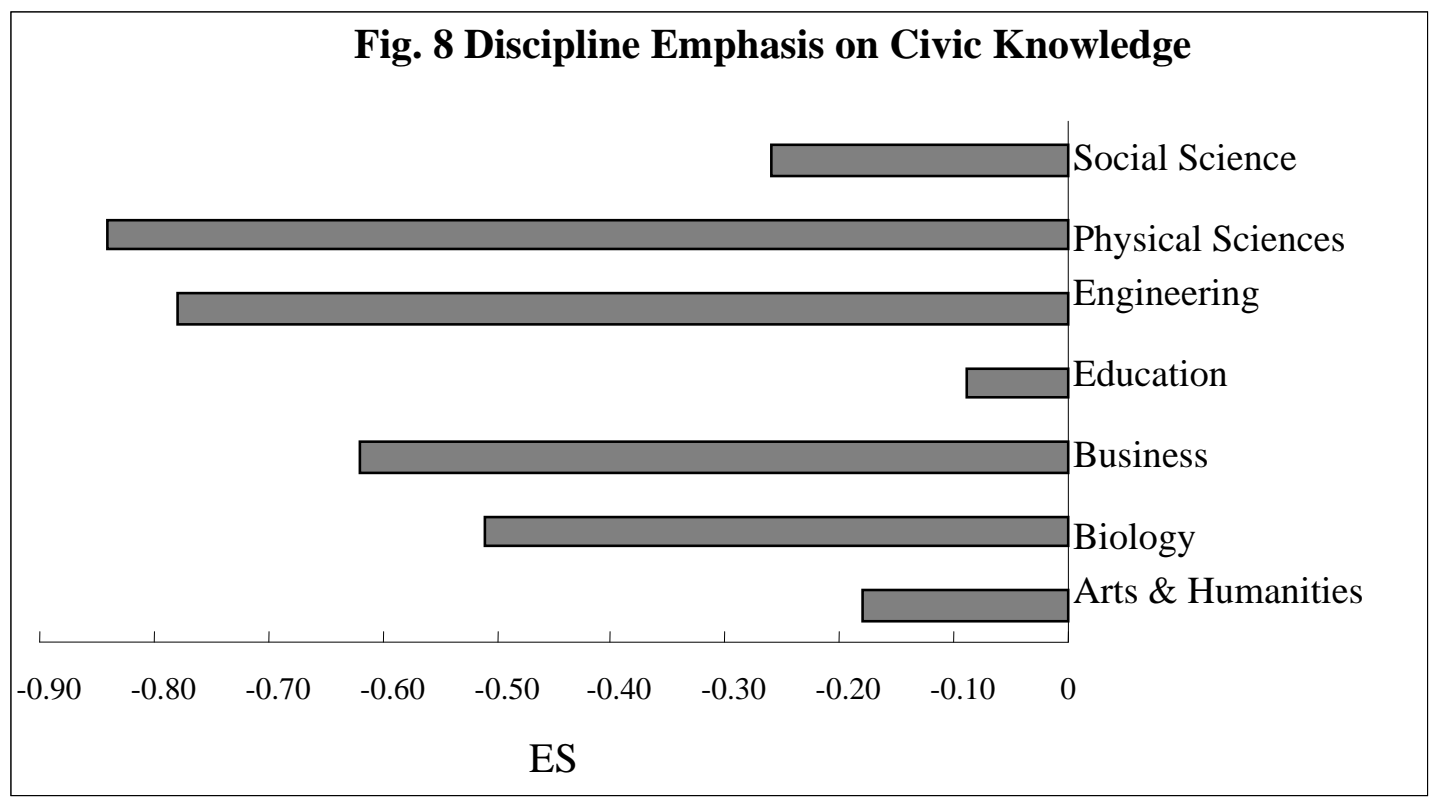

The results for ELO (7) Intercultural Knowledge and Competence, indicates average faculty members emphasized this skill "some” (mean 2.36, comparatively low). However, faculty members in Arts and Humanities give it the strongest support (mean, 2.78, and ES is .58, $p<.001$ with control) and support from other disciplines ranking from high to low is in such order: Social Sciences, Education, Professional, Business, Biology, Physical Sciences and Engineering. Compared with Professional, the ES for Arts \& Humanities is .58, Biology - .48, Business - 0.31, Engineering -.77, Physical Sciences - .62, Social Sciences .16 ( $p<.001$, all with control), as illustrated in Figure 9. The ESs for all disciplines are appreciable except ES for Education (.09 with control). For example, comparing Arts and Humanities with Engineering, which have the highest and the lowest mean scores respectively on ELO (7), we found the ES is 1.35 . That identifies about $92 \%$ of faculty from Engineering emphasized less on Intercultural Knowledge and Competence than faculty members in Arts and Humanities did. 


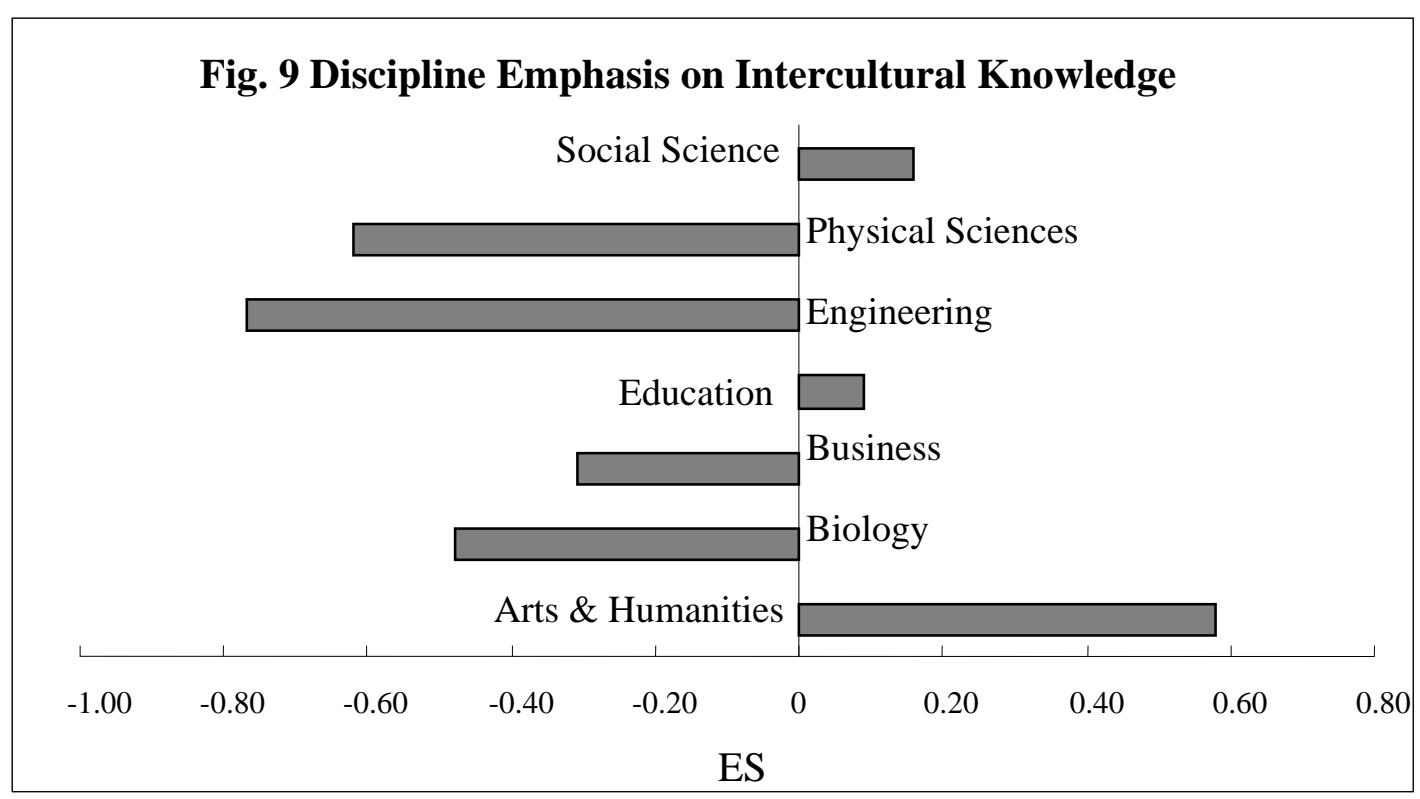

ELO (8) Ethical Reasoning and Action: The average faculty members emphasized this competence between "some” and 'quite a bit” (mean 2.46, comparatively low). However, faculty members in Education gave it the strongest support (mean, 3.01, quite a bit) and support from other disciplines ranking from high to low is in such order: Professional, Arts \& Humanities, Social Sciences, Business, Engineering, Biology, Physical Sciences. Compared with Professional, the ES for Arts \& Humanities is -.19, Biology -.99, Business - .57. Engineering is - .85, Physical Sciences - 1.13, Social Sciences is -.46 ( $p<.001$, all with control) as show in Figure 10. These are medium to big ESs and the differences in magnitude between them are appreciable. For example, the ES for Physical Sciences is 1.20 compared with Education, which indicates $88 \%$ of faculty from Physical Sciences emphasized Ethical Reasoning and Action less than faculty members did in Education. 


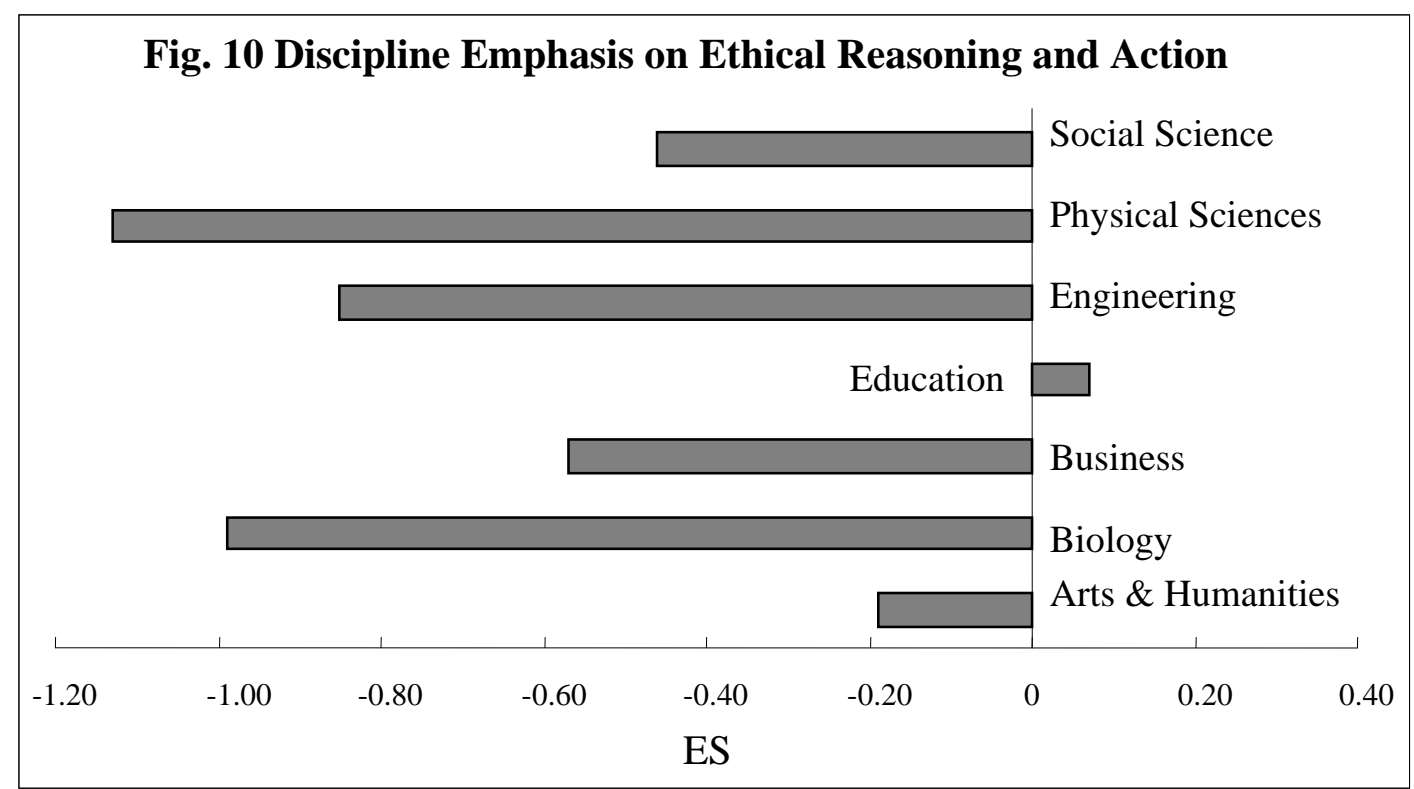

ELO (9) Foundations and Skills for Life Long Learning: we found the average faculty members emphasized this competence “quite a bit” (mean 3.22)

Faculty members in Arts \& Humanities emphasized it the most (mean, 3.43, and ES is $.22, p<.001$ with control), and support from other disciplines ranking from high to low is in such order: Professional, Education, Social Sciences, Physical Sciences, Biology, Business, and Engineering. Compared with Professional, the ES for Arts \& Humanities is .22, ES for Engineering is -.30, and ESs for others are trivial. See Figure 11. 


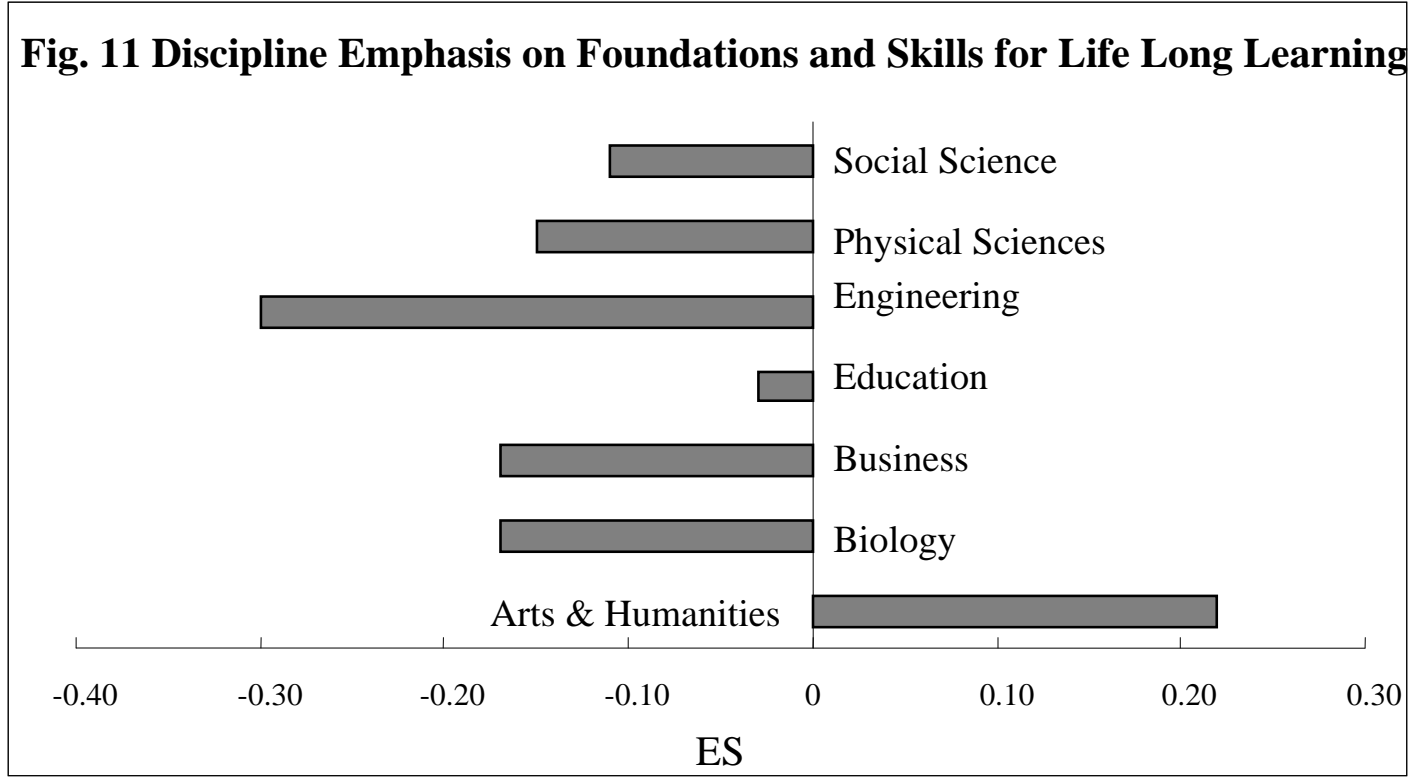

Regarding the emphasis on Foundation and Skill, the largest difference exists between Arts \& Humanities and Engineering: ES .52 indicate the average faculty members in Arts and Humanities emphasized the competence of Foundation and Skills on Life Long learning more than 69\% of faculty members in Engineering did.

ELO (10) Integrative learning: the average faculty members emphasized this competence “quite a bit” (mean 3.17). Faculty members in Education give the strongest support (mean, 3.45) and support from other disciplines ranking from high to low is in such order: Professional, Engineering, Business, Arts \& Humanities, Social Sciences, Biology, and Physical Sciences. Compared with Professional, the ES for Arts \& Humanities is -.49, Biology -.59, Business -.41. Engineering -.42, Physical Sciences - 1.11, Social Sciences is -.51 respectively (all with control) as illustrated in Figure 12. They are all appreciable ESs. 


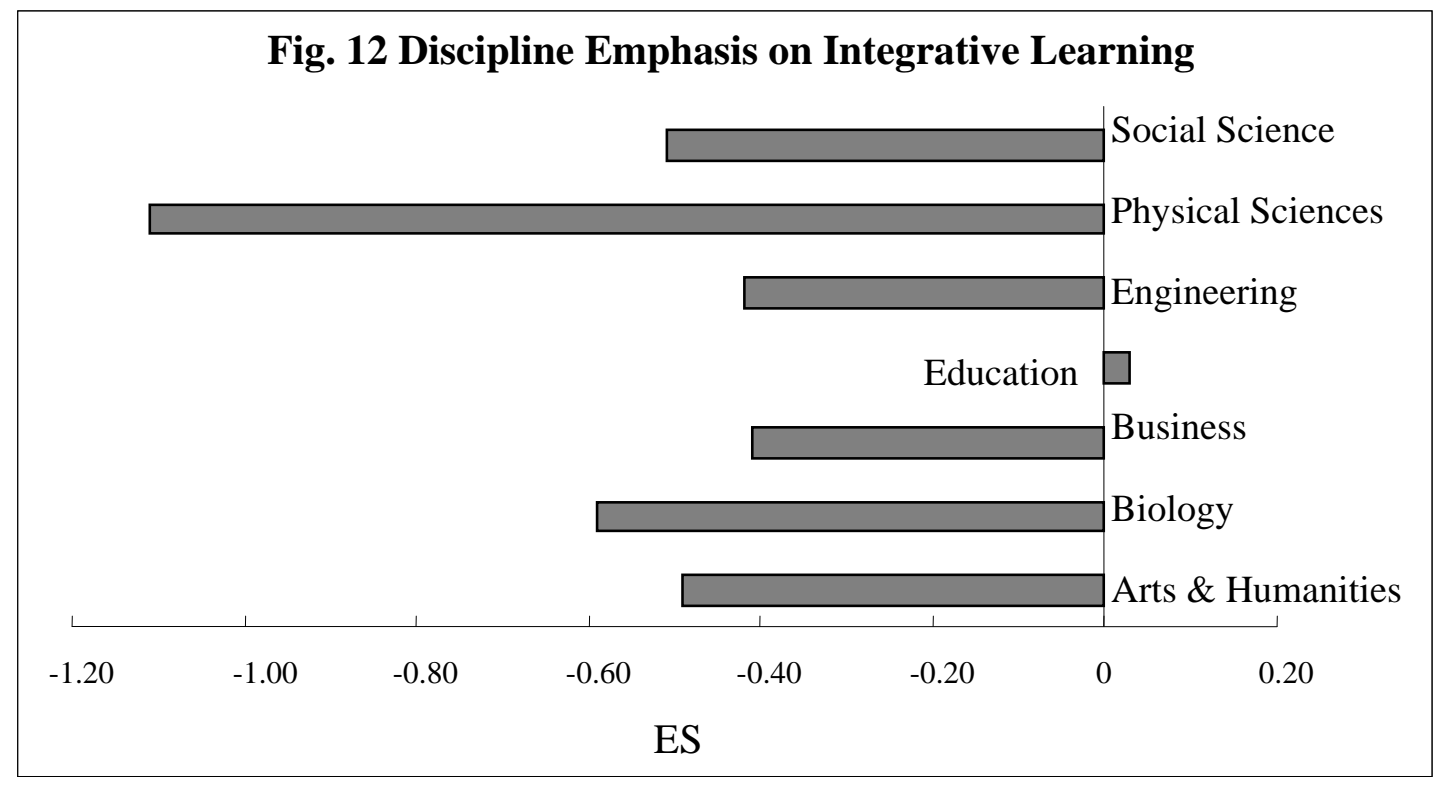

With the reported ESs, difference between any two groups can be found. For example, compared Education with Physical sciences, the ES is 1.14. This identified the more than $86 \%$ of faculty members in Physical sciences emphasized these skills less than the average faculty in Education did.

Research results for ELO 11, Problem Solving, shows average faculty members emphasized this competence "quite a bit" (mean 2.90). Faculty members in Education give it the strongest support (mean, 3.20) and support from other disciplines ranking from high to low is in such order: Professional, Business, Engineering, Social Sciences, Physical Sciences, Biology, Arts \& Humanities. Compared with Professional, the ES for Arts \& Humanities is - .61, Biology is - .61. Physical Sciences is -.49 ( $p<.001$, all with control). Other disciplines ES are trivial as seen in Figure 13 . 


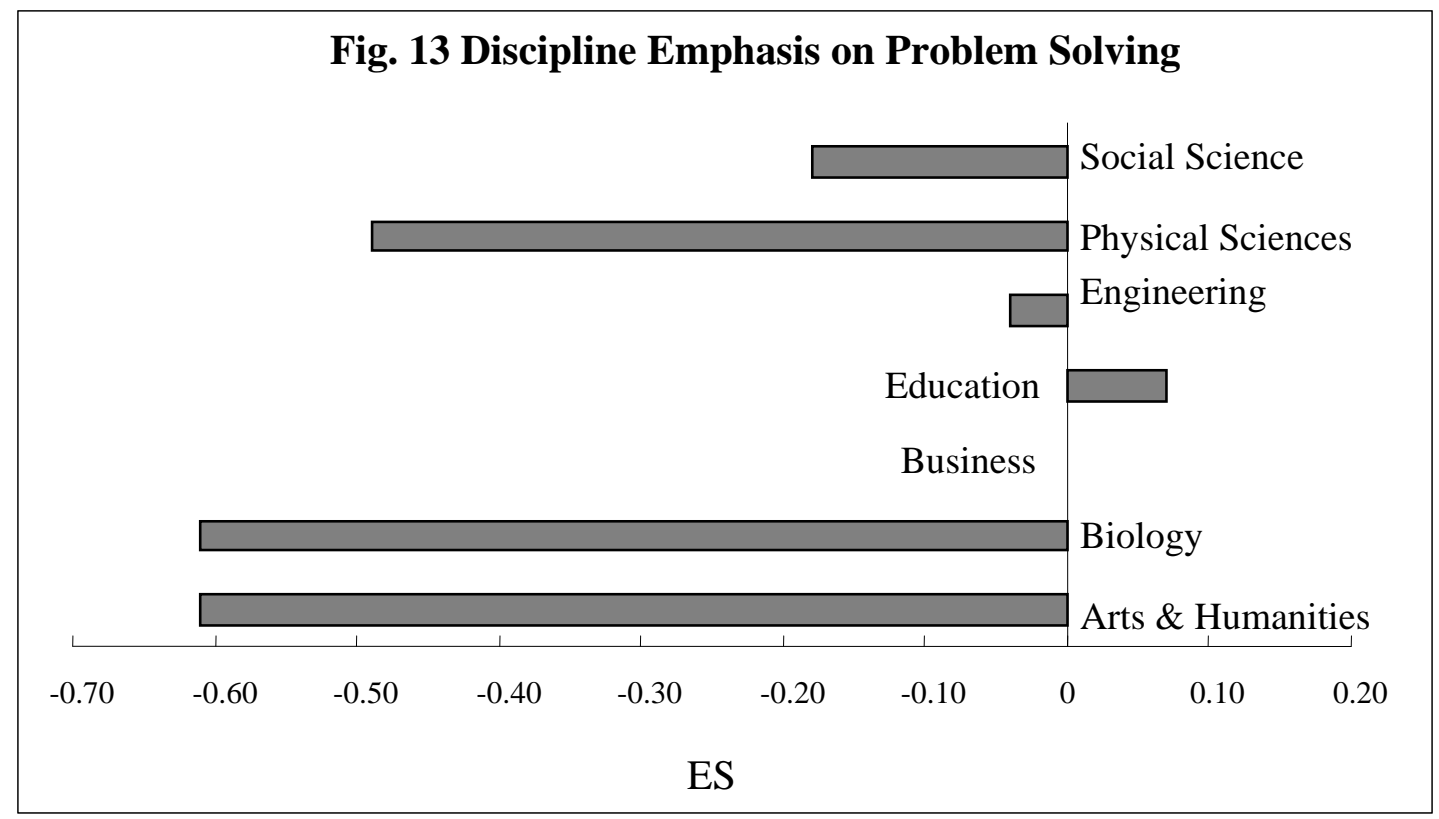

The largest difference exits between Education and Arts \& Humanities. The ES is .68, which indicates the average faculty members in Education emphasized more on Problem Solving than 73\% of faculty members of Arts and Humanities did.

AAC\&U (2005) pointed out that support for Essential Learning ELO (2) Written and Oral Communication, (3) Quantitative Literacy, (5) Team Work (6) Civic Knowledge and Engagement, (7) Intercultural Knowledge and Competence, and (8) Ethical Reasoning and Action are “considerably low” in American higher education. In fact, support for these ELOs is not only “considerably low,” but also has been consistently low for the past five years as seen in Table 53.

More attention to these ELOs would certainly be welcome. However, based on our research, even for these ELOs, faculty members from certain disciplines still place a lot more emphasis than the others did. The large range of ESs indicate, at some level, faculty in certain disciplines understand, that they are responsible for facilitate 
attainment of these skills and competencies that are critical for students' success in college and students’ lives after college.

Table 53

Faculty Report of Emphasizing Essential Learning Outcomes from 2004-2007

\begin{tabular}{|c|c|c|c|c|}
\hline Essential Learning Outcomes & $\begin{array}{l}2004 \\
\text { FSSE }\end{array}$ & $\begin{array}{l}2005 \\
\text { FSSE }\end{array}$ & $\begin{array}{l}2006 \\
\text { FSSE }\end{array}$ & $\begin{array}{l}2007 \\
\text { FSSE }\end{array}$ \\
\hline $\begin{array}{l}\text { Inquiry and analysis } \\
\text { Critical and creative thinking }\end{array}$ & $(21 c) * 93 \%$ & $93 \%$ & $93 \%$ & $94 \%$ \\
\hline $\begin{array}{l}\text { Written and oral } \\
\text { communication }\end{array}$ & $\begin{array}{l}(21 \mathrm{a}) * 61 \% \\
(21 \mathrm{~b}) * 49 \%\end{array}$ & $\begin{array}{l}63 \% \\
51 \%\end{array}$ & $\begin{array}{l}63 \% \\
51 \%\end{array}$ & $\begin{array}{l}62 \% \\
50 \%\end{array}$ \\
\hline Quantitative literacy & $(21 d) * 44 \%$ & $45 \%$ & $44 \%$ & $44 \%$ \\
\hline Information literacy & $\begin{array}{c}(5 \mathrm{~h}) * 91 \% \\
(20 \mathrm{~d}) * 73 \%\end{array}$ & $\begin{array}{l}89 \% \\
70 \%\end{array}$ & $\begin{array}{l}90 \% \\
73 \%\end{array}$ & $\begin{array}{l}90 \% \\
71 \%\end{array}$ \\
\hline Team work & $(21 f) * 55 \%$ & $56 \%$ & $59 \%$ & $57 \%$ \\
\hline $\begin{array}{l}\text { Civic knowledge and } \\
\text { engagement }\end{array}$ & $(1 b) * 54 \%$ & $55 \%$ & $58 \%$ & $57 \%$ \\
\hline $\begin{array}{l}\text { Intercultural knowledge and } \\
\text { competence }\end{array}$ & $\begin{array}{l}(1 \mathrm{f}) * 45 \% \\
(21 \mathrm{i}) * 41 \% \\
(5 \mathrm{c}) * 44 \%\end{array}$ & $\begin{array}{l}43 \% \\
42 \% \\
45 \%\end{array}$ & $\begin{array}{l}44 \% \\
45 \% \\
45 \%\end{array}$ & $\begin{array}{l}44 \% \\
45 \% \\
47 \%\end{array}$ \\
\hline Ethnical reasoning and action & $\begin{array}{l}(21 \mathrm{k}) * 50 \% \\
(21 \mathrm{~h}) * 51 \%\end{array}$ & $\begin{array}{l}49 \% \\
54 \%\end{array}$ & $\begin{array}{l}51 \% \\
53 \%\end{array}$ & $\begin{array}{l}51 \% \\
52 \%\end{array}$ \\
\hline $\begin{array}{l}\text { Foundation and skills for life } \\
\text { long learning } \\
\text { Problem Solving }\end{array}$ & $(21 g) * 87 \%$ & $83 \%$ & $86 \%$ & $85 \%$ \\
\hline
\end{tabular}

Note: * These are the survey items in FSSE (2004). AAC\&U (2005) chose them to indicate how much faculties emphasize the essential learning outcomes (AAC\&U, 2005, p.4). The percentages indicate that faculty states they emphasize each item as "quite a bit” or "very much.” This table accumulated the same items from FSSE 2004-2007 (http://fsse.iub.edu/html/archives.cfm)

Previous research has revealed that students benefit from what faculty emphasized, not only regarding improving their intellectual skills as in writing and quantitative literacy, but also in team work, civic knowledge and engagement, intercultural knowledge, ethical reasoning and action (Bok, 2006, Pace, 1990; 
Pascarella \& Terenzini, 2005). Perhaps if faculty members across disciplines were more intentional about emphasizing these ELOs, more students would benefit in desired ways.

Faculty in Private and Public Institutions' Support for ELOs

Faculty members from private and public higher institution differed significantly $(\mathrm{p}<.01)$ on five of the 11 ELOs (Table 7, Column 6, p.64). The differences in magnitude between them are modest to trivial (Table 53).

Ratcliff, Johnson, La Nasa and Gaff (2000) summarized a national survey of the status of general education, and reported that between 1990 and 2000, state legislatures, state governing boards and regional accrediting bodies had increased influence on general education requirement, especially to the public institutions; 56\% of public institutions reported governing agencies influence. Therefore, we investigated if Institution Types of Control and Accreditation Regions have any effect on faculty members' report of fostering ELOs.

Regarding the 11 recommended ELOs, emphasis given by faculty members from private and public institutions differed significantly $(p<.01)$ on five ELOs (Table 7, column 6). They are (1) Inquiry, Analysis, Critical and Creative Thinking, (2) Written and Oral Communication, (6) Civic Knowledge and Engagement, (7) Intercultural Knowledge and Competence, (8) Ethical Reasoning and Action. On each of the five significant ELOs, faculty members from Private institutions emphasized these ELOs slightly more than faculty members from public group did. However, the differences in magnitude are modest to trivial especially after we removed the influence of control variables. Compared to Private, the ESs for Public on each of the 
five ELOs are -.08, -.19, -.19, -.22, -.15 (all without control) respectively, and -.13, $.07,-.08,-.15,-.13$ (all with control) respectively. These differences are modest to trivial.

It seems the state legislatures, and state governing boards have not made much difference in Public institutions. Bok (2006) pointed out mandating credit hours for general education, or subject to be taught are not going to "break through the crust of inertia and complacency that keeps most colleges from challenging accustomed way of teaching” (p.154). A better role for government officials would be to examine what colleges are doing to assess their own performances, to identify their significant weaknesses, and how they make use of what they find to attempt improvements. Faculty in Six Accreditation Regions Support the ELOs

Faculty members from six Accreditation Regions differed significantly $(p<$ .01) on emphasizing six of the 11ELOs (Table 7, Column 8, p.64). The differences in magnitude between these regions are appreciable (Table 53).

Faculty members from the six Accreditation Regions differed significantly (at least $p<.01$ ) on emphasizing six ELOs with no significant on others. The six significant ELOs include (2) Written and oral communication, (3) Quantitative literacy, (4) Information literacy, (6) Civic knowledge and engagement, (7) Intercultural knowledge and competence, (8) Ethical reasoning and action.

ELO (2) Written and Oral Communication: ranking from high to low, faculty members emphasized this ELO in such order: Middle States, New England, Western, Southern, North Central, and North West. ESs for each of these regions are .25, .13, .03, -.04 compared with Western. Results are also illustrated in Figure 14. 


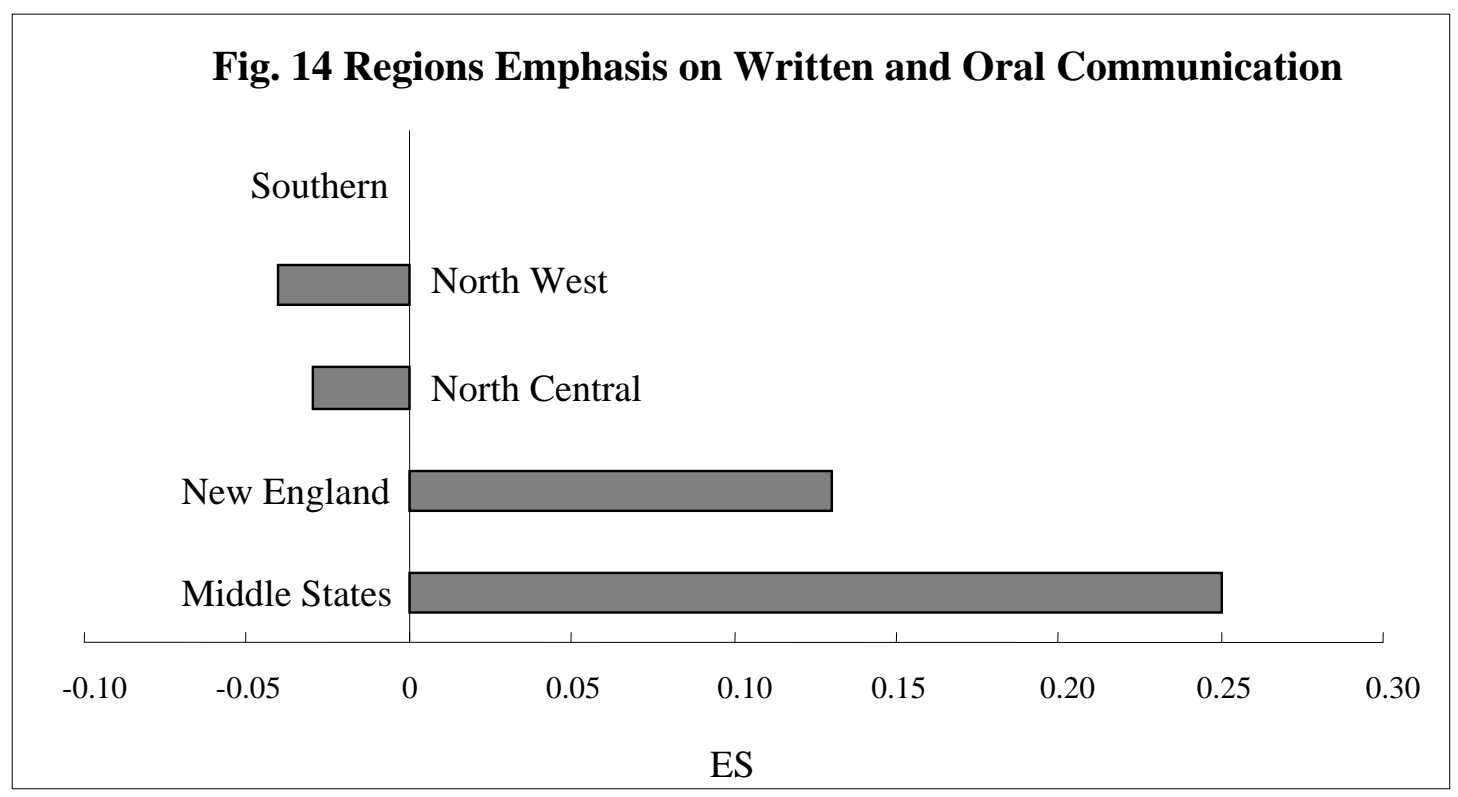

ELO (3) Quantitative Reasoning, faculty members from the six accreditation regions emphasized this ELO ranking from high to low in such order: Middle States, North West, North central, Southern, New England, and Western. ESs for each of these regions are .19, .04, .11, .11, .10 (all with control), compared with Western. Results are illustrated in Figure 15. 


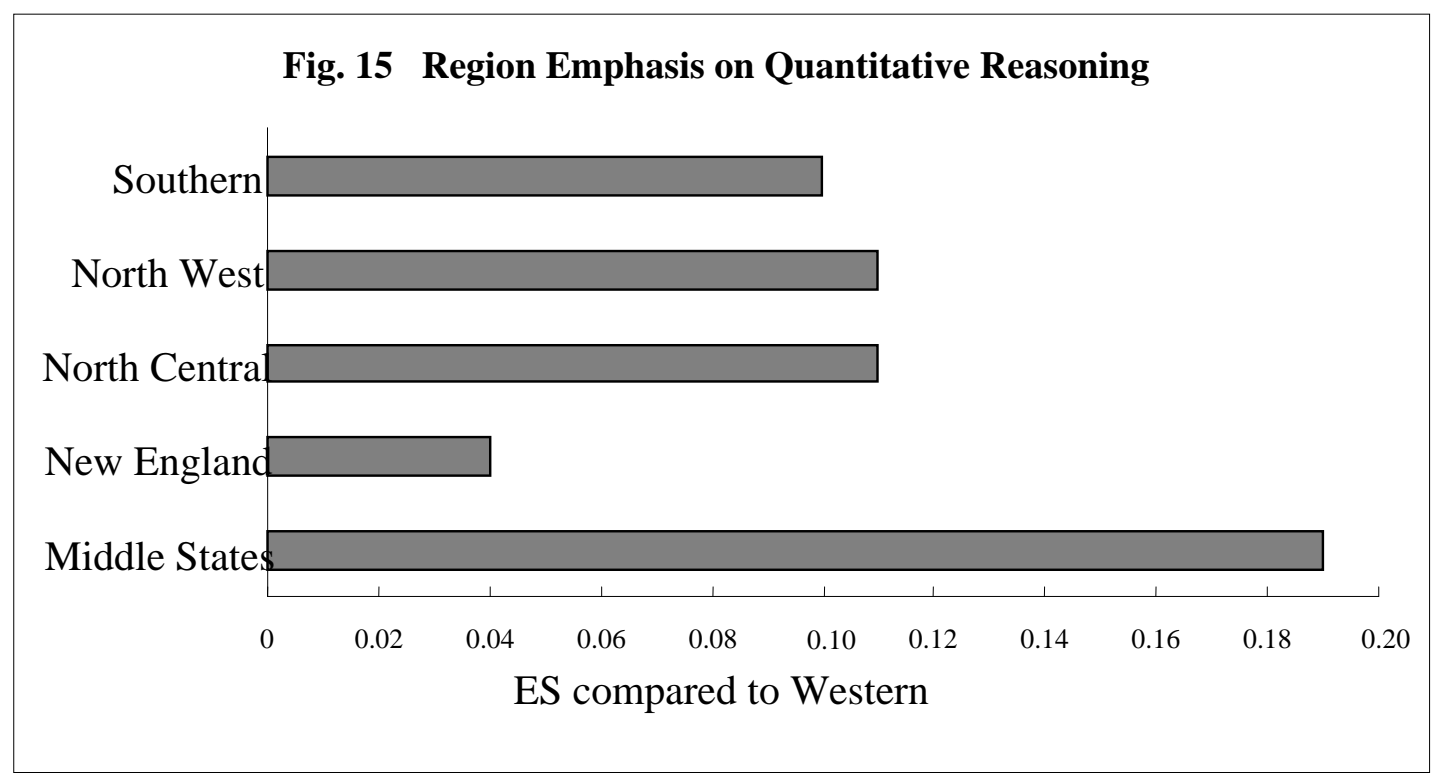

ELO (4) Information Literacy: The six regions ranks as Middle States, North West, Southern, North Central, Western, and New England based on faculty members report on emphasized Information Literacy. ES for each of these regions are .31, .10 $.06, .05,-.08$ (all with control) compared with Western. Results are also illustrated in Figure 16.

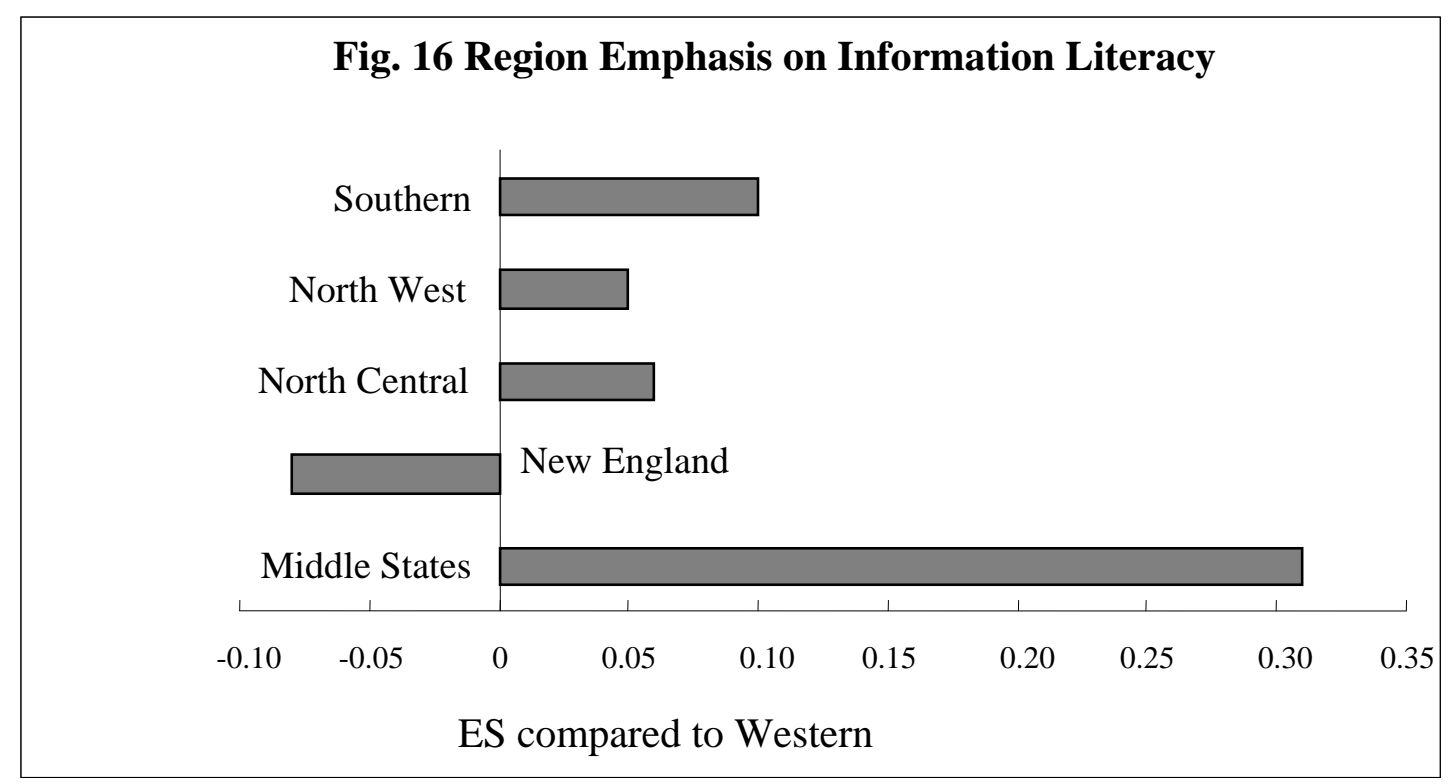


For emphasis on ELO (6) Civic Knowledge and Engagement, the ranking for six regions is as such: Middle States, Western, Southern, North Central, New England, and North West. ESs for each of these regions are .24, -.02 -.05, -.11, -.13 (all with control), respectively compared with Western. Results are also illustrated in Figure 17.

For ELO (7) Intercultural Knowledge and Competence, the ranking for six regions based is: Western, Middle States, Southern, New England, North Central, and North West. ESs for each of these regions are -.07, -.06 -.11, -..15, \& -.35 (all with control), respectively, compared with Western. Results are also illustrated in Figure 18.

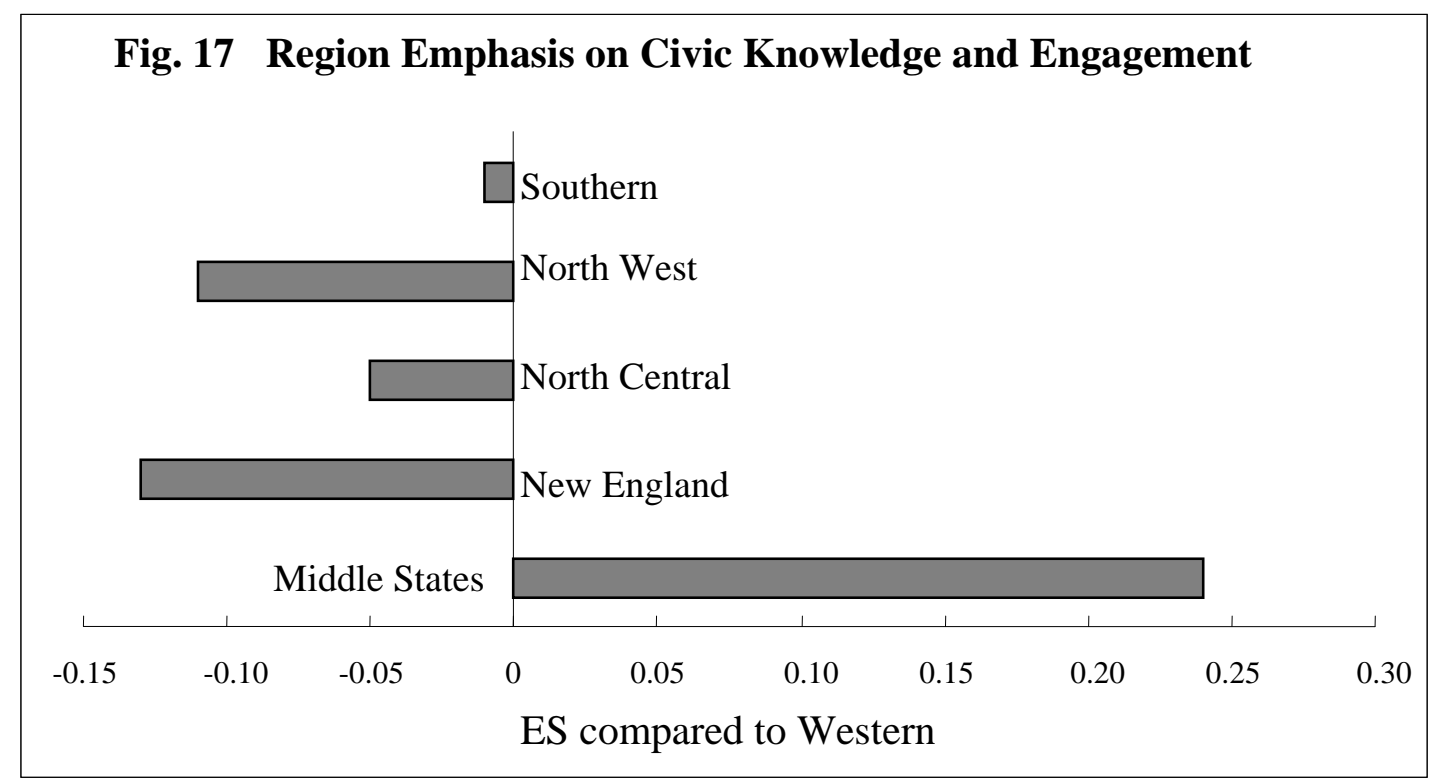

For ELO (8) Ethical Reasoning and Action, the ranking for six regions is Middle States, Western, Southern, New England, North Central, and North West. ESs for each of these regions are .09, -.03, -.10, -.17, \& -.19 (all with control), respectively, compared with Western. Results are also illustrated in Figure 19. 


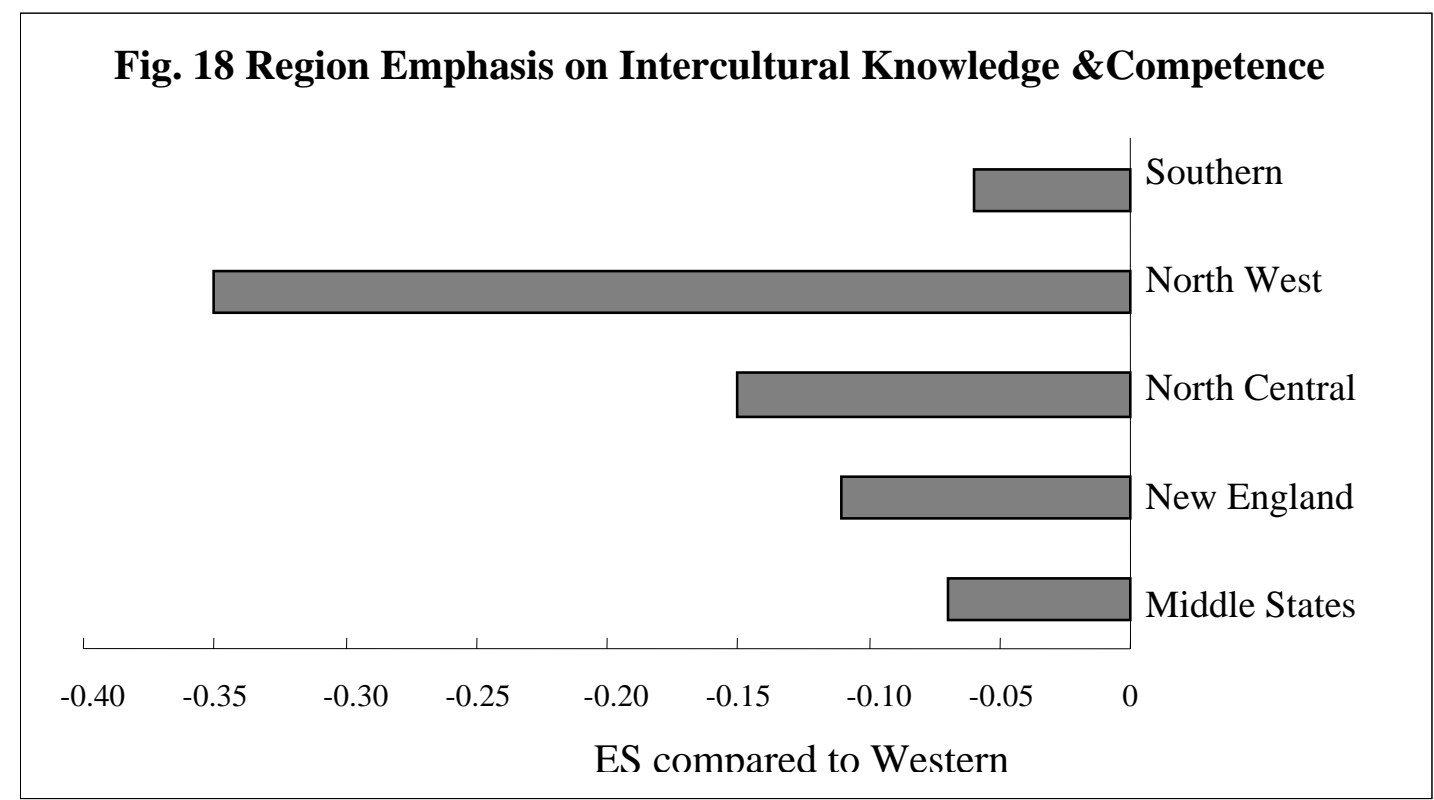

Fig. 19 Region Difference in Emphasis on Ethical Reasoning and Action

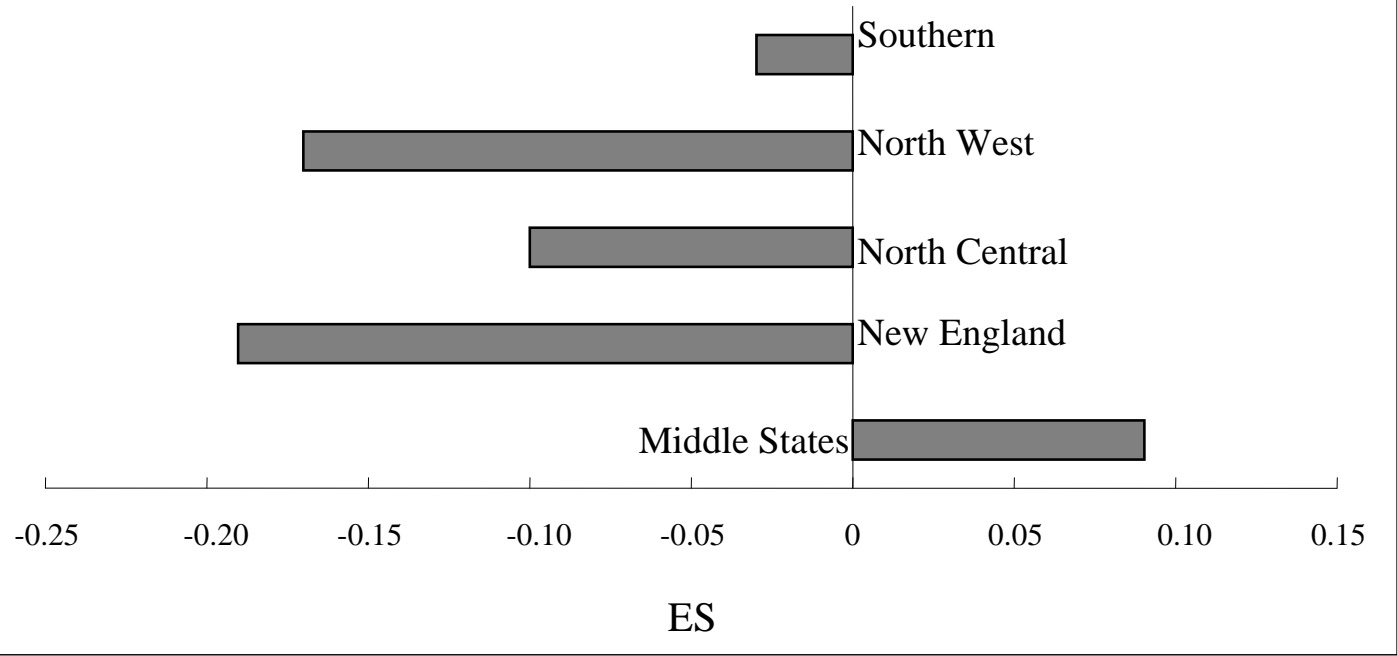

With all these reported ESs, we can find out differences in magnitude between any regions regarding any of the six significant ELOs. For example, the ES between Middle States and New England is .39 regarding Information Literacy, and that 
indicates the average faculty members in Middles States emphasized information literacy more than $66 \%$ of faculty members did in New England.

It may be noticed that among these six Accreditation Regions, Middle States ranks the highest on five of the six significant ELOs, and ranks in the second place on the remaining one ELO (ELO 7). The differences in magnitude between Middle States and the others (whichever ranks at the bottom) ranges from .19 to .39 (all with control). Is this pattern an influence of Middle States Commission on Higher Education? Do they identify student competencies to be achieved and make faculty members in this region more aware of fostering ELOs? Do they mandate learning outcome assessment? Or is it because more elite universities and colleges are allocated in this region? Further research is certainly needed for understanding these existing differences between accreditation regions. Faculty in the Three Types of Carnegie Institutions Support for the ELOs:

Faculty members from three Carnegie institutions differed significantly $(p<$ .01) on emphasizing five of the 11 recommended ELOs (Table 7, Column 5). The differences in magnitude between them are modest to trivial. (Table 53)

"Undergraduate education in the research university is becoming a project in ruins.” This is a concern expressed by Katz in his 2005 article, Liberal Education on the Ropes. In fact, this has been a concern over the last 100 years in American Higher Education (AAC\&U, 1987, Boyer 1987, Lucas 1994). The concerns are that most universities have given priority to research and graduate and professional training. Research faculty members have little interest in joining efforts to build core or general-education programs, much less in teaching them. On the other side, students' 
intellectual level, their motivation for "going to college," and their social and economic condition contribute to the "project in ruins.” Katz (2005) still believes that concept of liberal education is more alive in four year liberal arts colleges than in research universities.

Based on our research, we found faculty members from three Carnegie Classification institutions differed significantly $(p<.01)$ on emphasizing five of the 11 recommended ELOs (Table 7, column 5). These significant five ELOs are (2) Written and Oral Communication, (6) Civic Knowledge and Engagement, (7) Intercultural Knowledge and Competence, (8) Ethical Reasoning and Action, and (11) Problem Solving. Based on their mean score, faculty members from Doctoral emphasized slightly less than others on all these significant ELOs; faculty from Master's emphasized slightly higher on two of them ( 8 \& 11), and faculty from Baccalaureate institutions emphasized slightly higher on three of the significant ELOs (2, 6, \& 7). However, the ESs calculation did not find any appreciable ESs between these groups, especially when we partial out the influences of disciplines.

These findings do not reflect the conditions described by Kate "Liberal education for undergraduates in the research university...is in ruins” (Katz, 2005). Based on our study, faculty from all three Carnegie types of institutions tended to endorse ELOs. The differences that did exist were not substantial. For example, one might expect ELO 3, Quantitative Literacy, to be more strongly endorsed by Doctoral institutions than Master's or Baccalaureate. In fact, however, the difference in emphasis was not significant. 
As may be noted, the group of Baccalaureate includes both baccalaureate in liberal arts and baccalaureate in general. One way to find out if the differences between research universities and liberal arts colleges are considerable is to regroup the faculty members. However, based on the present findings, the differences between doctoral, master, and baccalaureate institutions are trivial. Faculty with Different Teaching Experiences' Support for the ELOs

Faculty members with different teaching experience differed significantly $(p<$ .01) on emphasizing three of the 11 ELOs (Table 7, Column 7, p.64). The differences in magnitude between them are modest to trivial (Table 53).

In Contemporary Understandings of Liberal Education, Schneider \& Schoenberg pointed out "American higher education is in a period of transformative change” (http://www.aacu.org/publications/ContemporaryUnderstandings.cfm\#teaching). The changes reflect a shift from teaching to a learning paradigm and the incorporation of information technology into the fabric of undergraduate education. To these changes, teachers across the forty-year age span exhibit generational differences in their sense of the desirability and urgency of change. To find out if teaching experiences have effect on the ELOs, we categorized faculty members into four groups with 1-4 year, 59 year, 10-14 year and 15 or more teaching experience.

We found that faculty members with different teaching experience differed significantly on emphasizing three of the 11 ELOs (Table 7, Column 7). These significant three are (5) Team Work, (8) Ethical Reasoning and Action, and (10) Integrative Learning. 
Regarding Team Work, faculty members in the group of 5-9 year emphasized the most, group 1-4 year and group 10-14 year are the same ranking in the second place, and group 15 or more years emphasized the least. Compared with the group of 15 or more years, the ES for 1-4 year group is .16, 5-9 year group is .25, and 10-14 year group is .16. (all without control, $p<.001$ ). Introducing control variables slightly reduced the ESs. They become $.05, .19$, and .13 respectively.

ELO (8) Ethical Reasoning and Action: Although ANOVA test indicated the four groups of faculty members with difference in teaching experience differed significantly $(p<.01)$, the ES analysis did not find any appreciable differences between these groups.

ELO (10) Integrative Learning: Again, faculty members in 5-9 year group emphasized it the most, then the group 10-14 years, then 1-4 year group, and faculty members in 15 or more year emphasized it the least. ES for the group 5-9 year is .20, for the group of $10-14$ years is .15, and for 1-4 year group is .10 (all without control) compared with the group of 15 or more years. Introducing control variables reduced the ESs. They become $.14, .12$, and .05 respectively.

It is interesting to note that faculty members in the 5-9 year group emphasized on both Team Work (ELO 5) and Integrative Learning (ELO 10) more than the other groups did. Faculty members in 15 or more years put less emphasis on Team Work and Integrative Learning than all groups did, as seen in Figure 20. Certainly, emphasizing Team Work and Integrative Learning does not amount to the paradigm change, but practicing them appropriately should help to make the changes happen. 


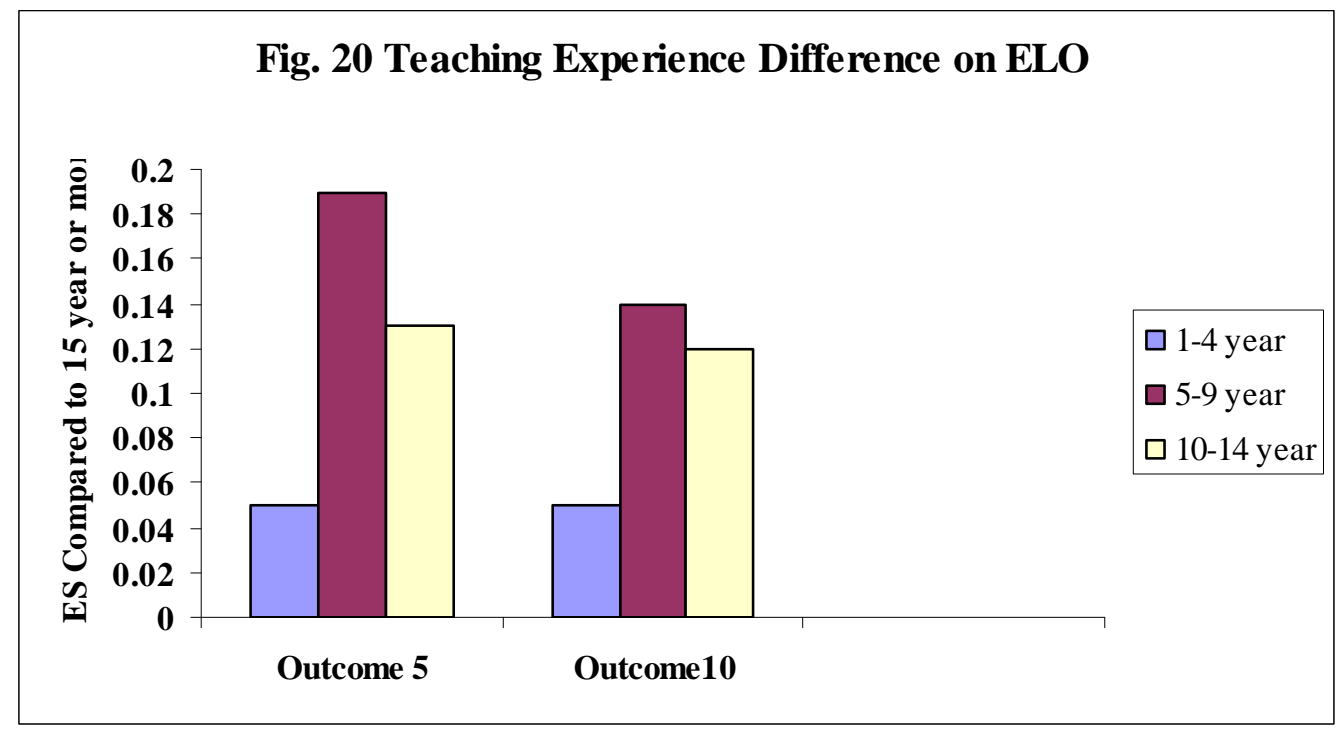

Summary of the Report

Summing up our systematic study of faculty members' incorporation of Essential Learning Outcomes across disciplines, types of institution, accreditation regions, and years of teaching experiences, we conclude:

1. The two groups of faculty (one is from professional and applied fields, and the other is from all remaining disciplines) differed significantly $(p<.01)$ on endorsing eight of the 11 ELOs. Faculty members from professional and applied fields emphasized more on six of the eight significant ELOs than faculty members from others did. Most of the differences in magnitude are appreciable.

2. The two groups of faculty (one is from professional, and the other is a combination of applied and the remaining disciplines) differed significantly $(p<.01)$ on six of the 11 ELOs. Regarding these six significant ELOs, faculty members in professional gave more emphasis than others did, and the differences in magnitude are appreciable. 
3. Faculty members across disciplines differed significantly $(p<.01)$ on endorsing each of the 11 ELOs, and most of the differences in magnitude are large.

4. Faculty members from private and public higher institution differed significantly $(p<.01)$ on five of the 11 ELOs. The differences in magnitude between them are modest to trivial.

5. Faculty members from six Accreditation Regions differed significantly $(p<$ .01) on emphasizing six of the 11ELOs. The differences in magnitude between these regions are appreciable.

6. Faculty members from the three Classification of Carnegie institutions differed significantly $(p<.01)$ on emphasizing five of the 11 ELOs. The differences in magnitude between them are modest to trivial.

7. Faculty members with different teaching experience differed significantly ( $p$ $<.01)$ on emphasizing three of the 11 ELOs. The differences in magnitude between them are modest to trivial.

These findings should enhance awareness of existing practice and perceptions of liberal education by faculty members. They constitute valuable information for governing boards, accreditation agencies, and academic leaders. For example, AAC\&U (2007) indicates that the Accrediting Board for Engineering and Technology (ABET) now looks for evidence that engineering programs are teaching students to integrate their liberal arts competences (Essential Learning Outcomes) with their technical studies (AAC\&U, 2007). In this regard, we have provided them evidences that can be illustrated in Figure 21. 


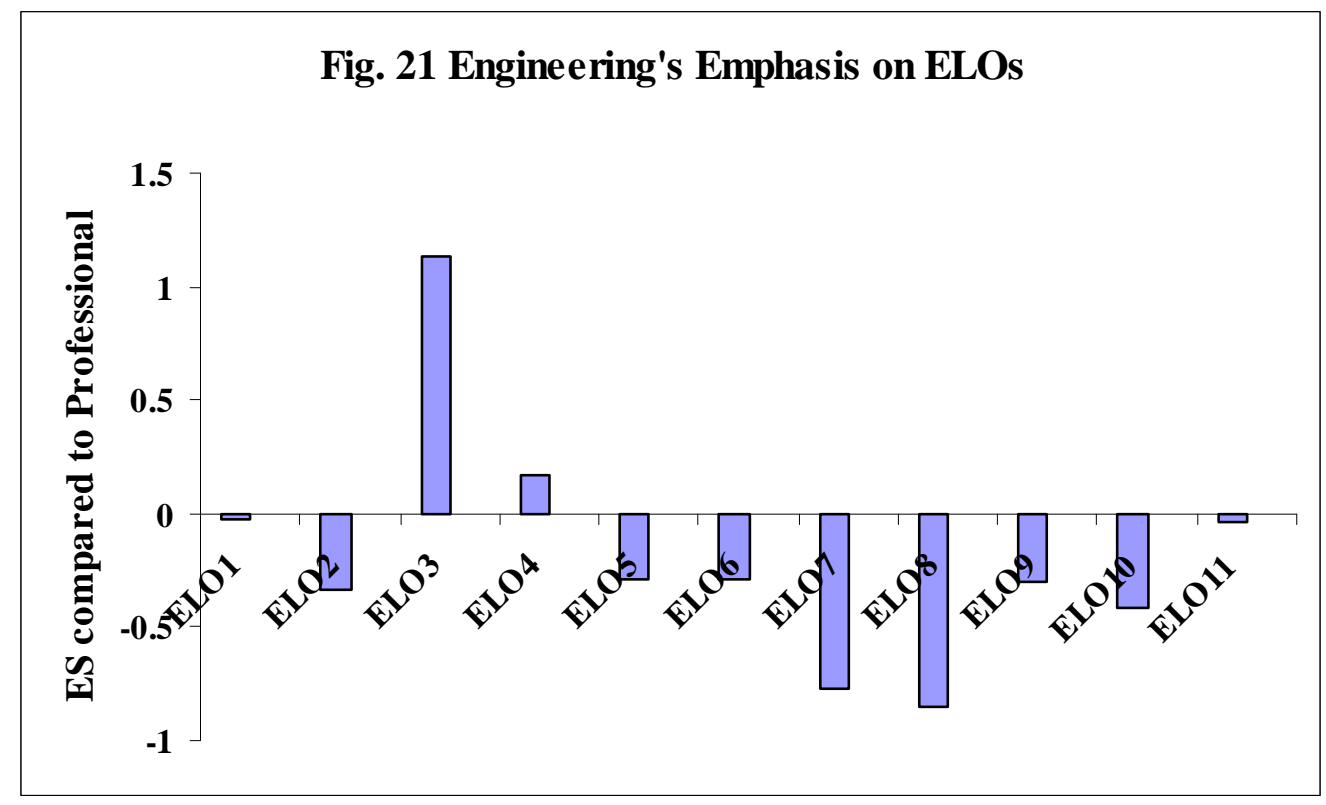

What are the weaknesses, what the strengths, and what learning skills and competences need to be reinforced in the engineering fields are obvious. We have provided evidences of faculty practicing Essential Learning Outcomes (ELOs) not only for engineering, but also for all academic disciplines, accreditation regions, and type of institutions. These data can facilitate decisions makings and support mechanisms for governing boards, accreditation agencies, and academic leaders.

If we value liberal learning, we should use these findings to improve performance. We should fill gaps in current practice in order to develop a more coherent and pervasive institutional climate for students to achieve the Essential Learning Outcomes (ELOs). Recommendations for Further Studies

The study was largely exploratory in nature. Although many differences were found among faculty members with different fields of study, teaching experience, academic disciplines, types of institutions, and accreditation regions, we do not know 
if students' reports would show the same patterns. Neither do we know the proximal causes of these differences. Learning never takes place without students. Studying students report of these Essential Learning Outcomes, and understanding why the differences exit or do not exist for both faculties and students are important areas for future research. Such inquiries could be instructive for efforts of improving learning at various levels, such as national dialogues as well as for local institutions.

1. A parallel study of NSSE, which is the student version of the FSSE, is recommended. It should provide more inclusive information about current practice of liberal education.

2. Regional accrediting bodies had increased influence on general education (liberal education). Their influence comes through the prescription of subjects to be taught, courses to be offered and/or student competencies to be achieved, learning outcome to be assessed. However, each of the six regional accreditations had different regulations, and policies. A comparison policy study over the past five to 10 years may help us to explain some of the significant differences that exist between them.

3. Similarly, a policy study of professional accreditations and applied fields regarding general learning objectives should also be insightful.

4. We also recommend doing a comparison study between the two groups of faculty members: one is faculty in research universities and the other is faculty of baccalaureate in liberal arts. Maybe in such a design, we can find out if the concept of liberal education is more alive in liberal arts colleges.

5. Neither report from faculty, nor students are direct measure of student learning. They are all indirect measures. Finally, we still need to directly assess 
Faculty and Learning Outcomes145

students' cumulative progress in achieve the Essential Learning Outcomes, and to audit the connections between intended learning and student accomplishment. 


\section{References}

Association of American Colleges and Universities (2005). Liberal education outcomes: A preliminary report on student achievement in college. Washington, D.C.: Author.

Association of American Colleges and Universities. (1998). Contemporary understandings of liberal education. Washington, DC: Author

Association of American Colleges and Universities. (2007). College learning for the new global century: A report from the national leadership council for liberal education \& America's promise. Washington, D.C.: Author.

Association of American Colleges. (1985). Integrity in the college curriculum. Washington, DC: Author.

Association of American Colleges. (1991). Liberal learning and the arts and science major: The challenge of connecting learning, (1). Washington, D.C.: Author.

Association of American Colleges. (1992). Liberal learning and the arts and science major: Program review and educational quality in the major, (3). Washington, DC: Author.

Astin, A. (1993). What matters in college? San Francisco: Jossey-Bass

Adelman, C. (2004). “Global Preparedness” of Pre-9/11 College Graduates: What the Longitudinal Studies Say. Tertiary Education and Management, 10, 243-260.

Bennett, W. J (1984) To Reclaim a Legacy: A report on the humanities in higher education. Washington, D.C.: National Endowment for the Humanities. 
Biglan, A. (1973a). The Characteristics of Subject Matter in Different Scientific Areas. Journal of Applied Psychology, 57, 195-203.

Biglan, A. (1973b). Relationships between subject matter characteristics and the structure and output of University Departments. Journal of Applied Psychology, 57, 1502-1213.

Bloom, A. (1987). The closing of the American mind. New York, NY: Simon \& Schuster.

Bok, D. (2006). Our underachieving colleges: A candid look at how much students learn and why they should be learning more. Princeton, NJ: Princeton University Press.

Boyer, E.L. (1987). College: The undergraduate experience in an America. New York, N.Y: Harper \& Row.

Braxton, J.M. \& Hargens, L.L. (1996) Variation among academic disciplines: analytical frameworks and research. In J.C. Smart (Ed.), Higher Education Handbook of Theory and Research, XI, pp.1-46

Brint, S. (2002). The rise of the "practical arts." In S.Brint (ED.), The future of the city of intellect (pp.231-259). Stanford, CA: Stanford University Press.

Brubacher, J.S. \& Rudy, W. (1958). Higher education in transition: An American history: 1636-1956. New York, N.Y: Harper \& Brothers Publication.

Carnegie Council on Policy Studies in Higher Education.(1977). The states and private higher education: Problems and policies in a new era: A report of the 
Carnegie Council on Policy Studies in Higher Education. San Francisco, CA: Jossey-Bass.

Chickering, A. W. \& Gamson, Z. F. (1987). Seven principles for good practice in undergraduate education. AAHE Bulletin, 39(7), 3-7.

Chickering, A. W. (1982). Liberal education and work. National Forum: Phi Kappa Phi Journal, 62(2), 22-23.

Coe, R. (2002). It's the effect size, stupid: What effect size is and why it is important. Retrieved from http://www.leeds.ac.uk/educol/documents/00002182.htm November 30, 2007.

Cohen, A.M. (1998). The shaping of American higher education: Emergence and growth of the contemporary system. San Francisco, CA: Jossey-Bass.

Cohen, J. (1977) Statistical power analysis for the behavioral sciences, $2^{\text {nd }}$ Ed. New York: Academic Press.

Cohen, J (1965). Some statistical Issues in psychological research. In B.B. Wolman (Ed.) Handbook of Clinical Psychology, New York: McGraw-Hill.

Cohen, J (1994) The Earth is round ( $p<.05)$. American Psychologist, 49(12) 997-1003.

Curry, L., Wergin, F., \& Associates. (1993). Educating professionals: Responding to new expectations for competence and accountability. San Francisco, CA: Jossey-Bass

D’ Souza, D. (1991). Illiberal education: The politics of race and sex on campus. New York: Basic Books, 1987. 
Dressel, P.L., Mayhew, L.B., \& McGrath, E.J. (1960). The liberal arts as viewed by faculty members in professional schools. New York, N.Y.: Columbia University Press.

Durden, W. (2002). Liberal arts for all. Trusteeship, 10(2), 25-28.

Fang, B. (2004). Looking forward: Liberal education in the $21^{\text {st }}$ century. Liberal Education, 90, 8-13.

Green, C.S., III, \& Salem, R. (1998, Spring). Assessing the prospects for liberal learning and careers. New Directions for Teaching and Learning, 5-9.

Harvard Red Book, (1945) General education in a free society: Report of the Harvard Committee. Cambridge, MA: Harvard University Press.

Hersh, R. (1997). Intentions and perceptions. Change, 29(2), 16-23

Hinkle, D.E., Wiersma, W., \& Jurs, S.G. (2003). Applied statistics for the behavioral sciences. Boston-New York: Houghton Mifflin Company.

Hirsch, E. D., Jr. (1987). Cultural literacy. Boston: Houghton-Mifflin.

Hutchins, R.M. (1936). The higher learning in America. New Haven, CT: Yale University Press.

Hutchins, R.M. (1943). Education for freedom. Baton Rouge, LA: Louisiana State University Press.

Immerwahr, J., \& Harvey, J. (1995). What the public thinks of college. Chronicle of Higher Education, 41(3), 335-368. 
Searle, J. (1990). The Storm over university, New York Review of Book, 37(19), DECMBER $6^{\mathrm{TH}}$

Katz, S.N. (2005). Liberal education on the ropes. Chronicle of Higher Education, 51(30). P.B6-B9.

Kimball, R. (1990) Tenured Radicals. New York: Harper Collins.

Kimball, B.A (1988). The historical and cultural dimensions of the recent reports on undergraduate education. American Journal of Education, 293-322.

Kimball, B.A (1995). The Condition of American Liberal Education: Pragmatism and a Changing Tradition. New York, NY: College Board Publications.

Kuh, G. D. (2001). Assessing what really matters to student learning: Inside the National Survey of Student Engagement. Change, 33 (3), 10-17, 66.

Kuh, G.D. (2003). What we are learning about student engagement from NSSE. Change, 35(2), 24-32.

Laird, T. F., Niskode, A.S., \& Kuh, G.D.(2006). General education courses and the promotion of essential learning outcomes. Paper presented at the Annual Meeting of the Association for the Study of Higher Education, November 2-4, 2006. Anaheim, CA

Lucas, C.J. (1994). American higher education: A history. New York, NY: St. Martin’s Press.

National Institute for Higher Education. (1984). Involvement in learning: Realizing the potential of American higher education. Washington, D.C.: Author. 
Newman, J. H. (1853/1976). The idea of a university. London, Oxford University Press.

Pascarella, E., and Terezini, P. (1991). How college affects students. San Francisco: Jossey-bass.

Pascarella, E., and Terezini, P. (2005). How college affects students: Vol.2. A third decade of research. San Francisco: Jossey-bass.

Ratcliff, J.L., Johnson, D.K., La Nasa, S.M., \&Gaff, J.G. (2001). The status of general education in the year 2000: Summary of a national survey. Washington, DC: Association of American Colleges \& Universities

Reading, B. (1996) The university in ruins. Estate of Bill Readings.

Rudolph, F. (1990). The American college and university: A history. Athens: University of Georgia Press.

Scott, B. (1992). The "new practicality" revisited: Changes in the American college curriculum. Journal of Education, 174 (1), 87-103.

Snyder, P., \& Lawson, S. (1993) Evaluating results using corrected and uncorrected effect size estimates. Journal of Experimental Education, 61, 334-349

Stark, J. (1987). Liberal education and professional programs: Conflict, coexistence, or compatibility? New Directions for Higher Education, 15(1), 90-102.

Thelin, J.(2004). A history of American higher education. Baltimore: Johns Hopkins University Press. 
Truman Commission on Higher Education. (1947) Higher Education for Democracy: A Report of the President's Commission on Higher Education. Retrieved February, 18, 2008, from:

http://www.ed.uiuc.edu/courses/eol474/sp98/truman.html

Van Horn, C. E. (1995). Enhancing the connection between higher education and the workplace: A survey of employers. Denver, Co: State Higher Education

Wilkinson, L et al. (1999) Statistical methods in psychology journals: Guidelines and explanations. American Psychologist, 54(8). 594-604

Wilshire, B. (1990). Moral collapse of the university: Professionalism, purity, and alienation. Albany: State University of New York Press.

The Yale Report. Retrieved August, 18, 2007, from: (http://www.highered.org/resources/Yale/1828_curriculum.pdf) 
Attachment 1

Detailed Discipline Information

1=Arts and Humanities

Art, fine and applied

English (language and literature)

History

Journalism

Language and literature (except

English)

Music

Philosophy

Speech

Theater or drama

Theology or religion

Other arts \& humanities

2=Biological Sciences

Biology (general)

Biochemistry or biophysics

Botany

Environmental science

Marine (life) science

Microbiology or bacteriology

Other biological science

3=Business

Accounting

Business administration (general)

Finance

International business

Marketing

Management

Other business

4=Education

Business education

Elementary/middle school

education

Music or art education

Physical education or recreation

Secondary education

Special education

Other education

\section{5=Engineering}

Aero-/astronautical engineering

Civil engineering

Chemical engineering 
Electrical or electronic engineering

Industrial engineering

Materials engineering

Mechanical engineering

General/other engineering

6=Physical Science

Astronomy

Atmospheric science (including

meteorology)

Chemistry

Earth science (including geology)

Mathematics

Physics

Statistics

Other physical science

7=Professional

Architecture

Urban planning

Health technology (medical,

dental, laboratory)

Law

Library/archival science

Medicine

Dentistry

Veterinarian

Nursing

Pharmacy

Therapy (occupational, physical, speech)

Other professional

\section{8=Social Science}

Anthropology

Economics

Ethnic studies

Geography

Political science (including

government, international

relations)

Psychology

Social work

Sociology

Gender studies

Other social science 
Attachment 2

\section{The interpretation of Cohen's $d$}

\begin{tabular}{|c|c|c|c|c|}
\hline \multirow{3}{*}{$\begin{array}{l}\text { Cohen's } \\
\text { Standard }\end{array}$} & \multirow{3}{*}{$\begin{array}{c}\begin{array}{c}\text { Effect } \\
\text { Size }\end{array} \\
2.0 \\
\end{array}$} & \multirow{3}{*}{\begin{tabular}{|c|}
$\begin{array}{c}\text { Percentile } \\
\text { Standing }\end{array}$ \\
97.7 \\
\end{tabular}} & \multirow[b]{2}{*}{\begin{tabular}{|c|} 
Percent of \\
Nonoverlap
\end{tabular}} & \multirow{24}{*}{$\begin{array}{l}\text { Cohen (1988) hesitantly defined effect sizes as } \\
\text { "small, } d=.2, " \text { "medium, } d=.5, " \text { and "large, } d= \\
.8 \text { ", stating that "there is a certain risk in inherent in } \\
\text { offering conventional operational definitions for } \\
\text { those terms for use in power analysis in as diverse a } \\
\text { field of inquiry as behavioral science" (p. 25). }\end{array}$} \\
\hline & & & & \\
\hline & & & $81.1 \%$ & \\
\hline & 1.9 & 97.1 & $79.4 \%$ & \\
\hline & 1.8 & 96.4 & $77.4 \%$ & \\
\hline & 1.7 & 95.5 & $75.4 \%$ & \\
\hline & 1.6 & 94.5 & $73.1 \%$ & \\
\hline & 1.5 & 93.3 & $70.7 \%$ & \\
\hline & 1.4 & 91.9 & $68.1 \%$ & \\
\hline & 1.3 & 90 & $65.3 \%$ & \\
\hline & 1.2 & 88 & $62.2 \%$ & \\
\hline & 1.1 & 86 & $58.9 \%$ & \\
\hline & 1.0 & 84 & $55.4 \%$ & \\
\hline & 0.9 & 82 & $51.6 \%$ & \\
\hline LARGE & 0.8 & 79 & $47.4 \%$ & \\
\hline & 0.7 & 76 & $43.0 \%$ & \\
\hline & 0.6 & 73 & $38.2 \%$ & \\
\hline MEDIUM & 0.5 & 69 & $33.0 \%$ & \\
\hline & 0.4 & 66 & $27.4 \%$ & \\
\hline & 0.3 & 62 & $21.3 \%$ & \\
\hline SMALL & 0.2 & 58 & $14.7 \%$ & \\
\hline & 0.1 & 54 & $7.7 \%$ & \\
\hline & 0.0 & 50 & $0 \%$ & \\
\hline & & & & \\
\hline
\end{tabular}

http://web.uccs.edu/lbecker/Psy590/es.htm 